\title{
Case Study for ARRA-funded Ground- Source Heat Pump (GSHP) Demonstration at Oakland University
}

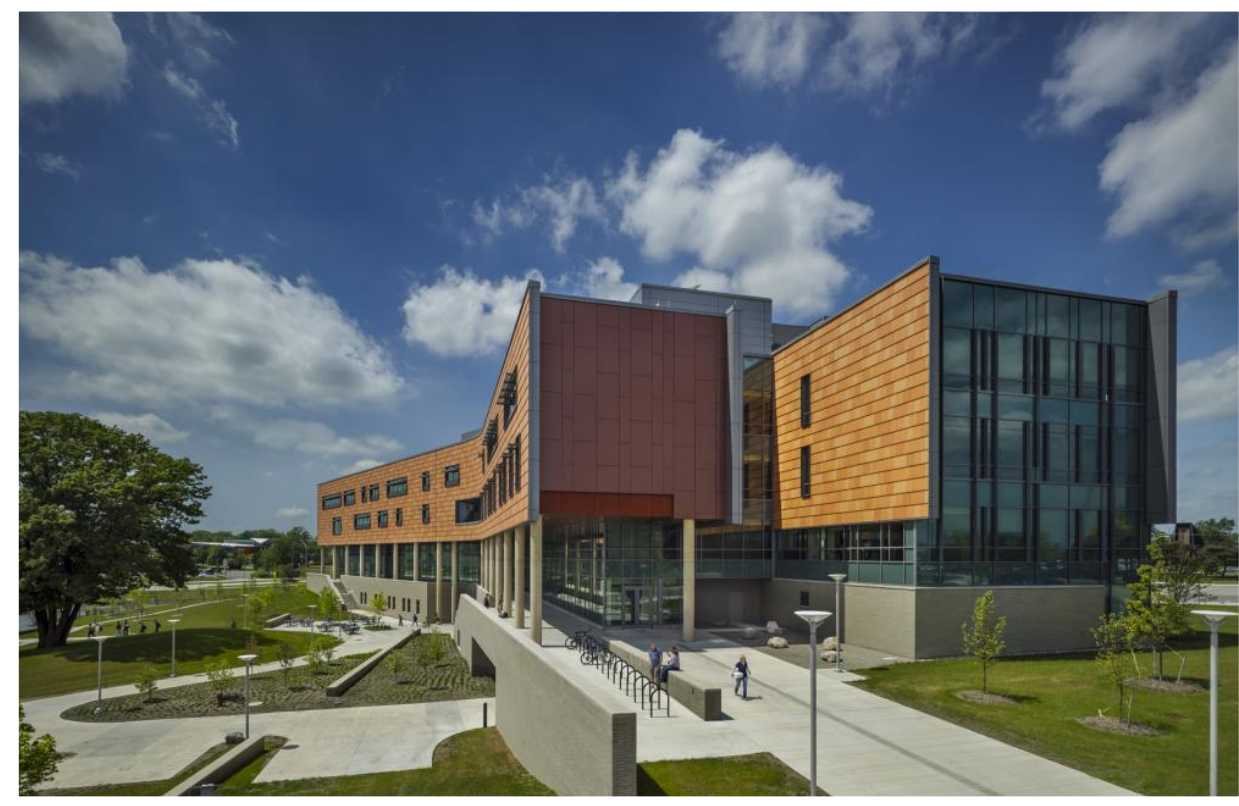

Piljae Im, PhD

Xiaobing Liu, PhD

September 2015 


\section{DOCUMENT AVAILABILITY}

Reports produced after January 1, 1996, are generally available free via the U.S. Department of Energy (DOE) Information Bridge.

Web site http://www.osti.gov/bridge

Reports produced before January 1, 1996, may be purchased by members of the public from the following source.

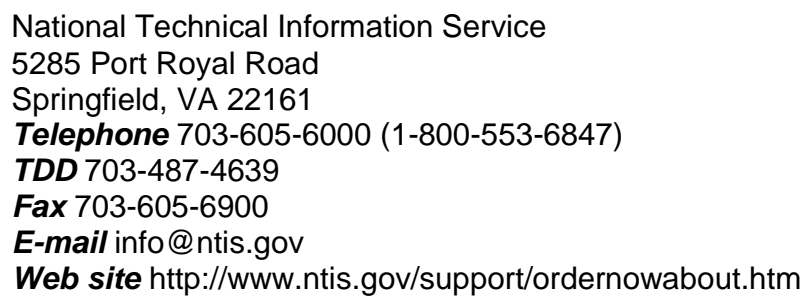

Reports are available to DOE employees, DOE contractors, Energy Technology Data Exchange (ETDE) representatives, and International Nuclear Information System (INIS) representatives from the following source.

Office of Scientific and Technical Information

P.O. Box 62

Oak Ridge, TN 37831

Telephone 865-576-8401

Fax 865-576-5728

E-mail reports@osti.gov

Web site http://www.osti.gov/contact.html

This report was prepared as an account of work sponsored by an agency of the United States Government. Neither the United States Government nor any agency thereof, nor any of their employees, makes any warranty, express or implied, or assumes any legal liability or responsibility for the accuracy, completeness, or usefulness of any information, apparatus, product, or process disclosed, or represents that its use would not infringe privately owned rights. Reference herein to any specific commercial product, process, or service by trade name, trademark, manufacturer, or otherwise, does not necessarily constitute or imply its endorsement, recommendation, or favoring by the United States Government or any agency thereof. The views and opinions of authors expressed herein do not necessarily state or reflect those of the United States Government or any agency thereof. 
Energy and Transportation Science Division

\section{Case Study for ARRA-funded Ground-Source Heat Pump (GSHP) Demonstration at Oakland University}

Piljae Im, Ph.D.

Xiaobing Liu, Ph.D.

Date Published:

September 2015

Prepared by

OAK RIDGE NATIONAL LABORATORY

Oak Ridge, Tennessee 37831-6283

managed by

UT-BATTELLE, LLC

for the

US DEPARTMENT OF ENERGY

under contract DE-AC05-00OR22725 



\section{CONTENTS}

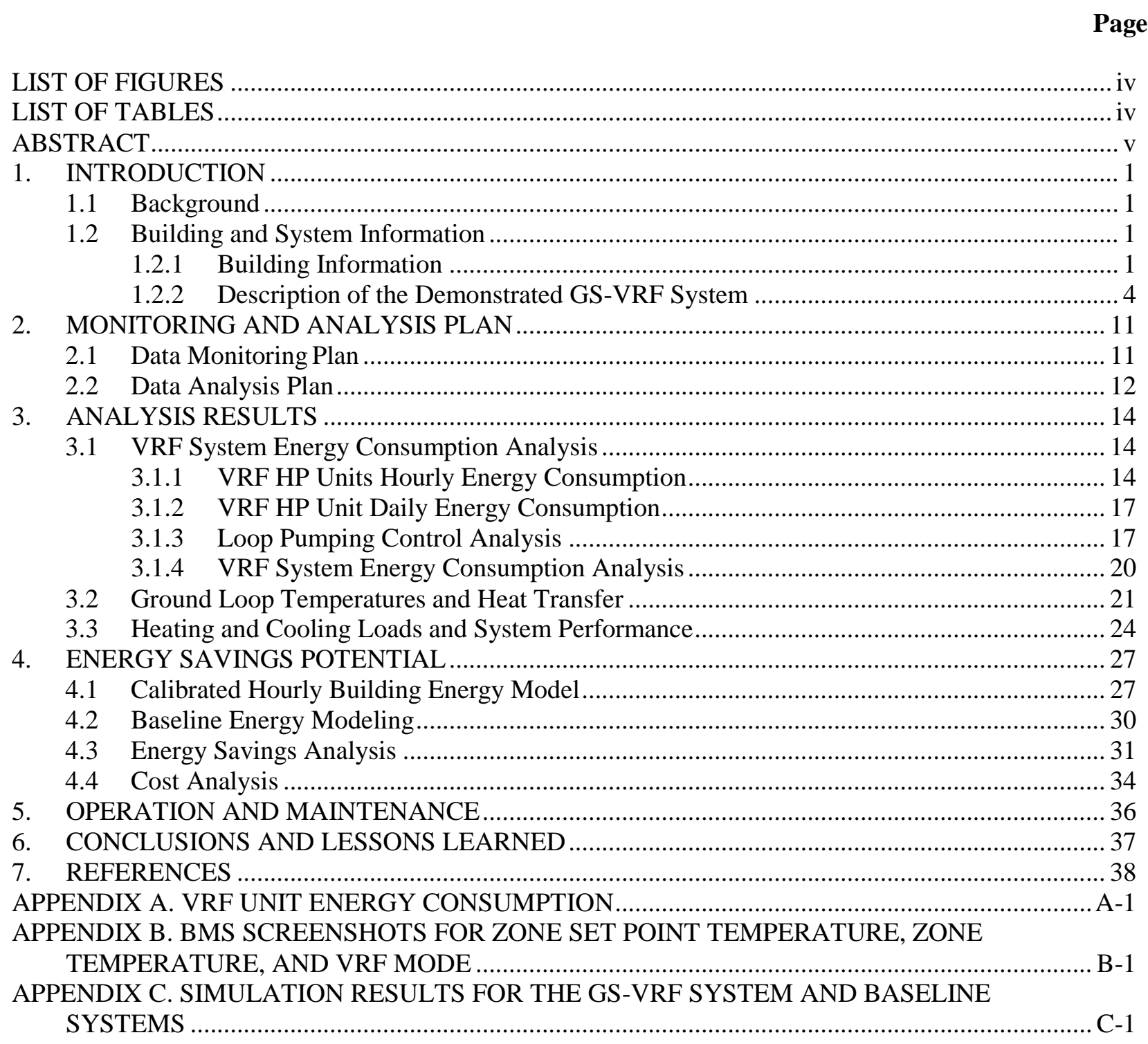




\section{LIST OF FIGURES}

Figure

1. Geographic location of the GSHP demonstration site at Oakland University.................................. 1

2. Human Health Building from the south view........................................................................... 2

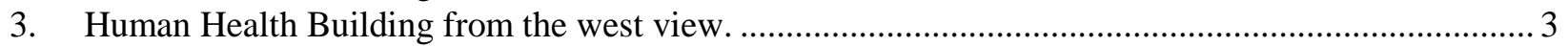

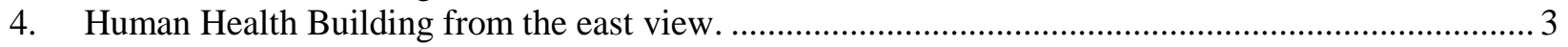

5. GS-VRF system schematic with monitored data points (CDH 2013) ........................................ 4

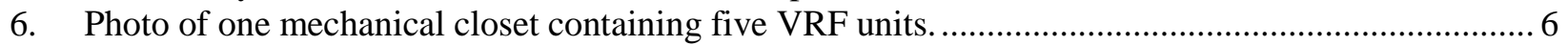

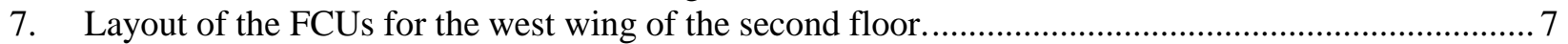

8. Photo of the installed ground-source heat pump chiller. ................................................................ 9

9. Aggregated power draw from all of the 50 VRF units in the building.......................................... 15

10. Trend of aggregated power draw of the 50 VRF units versus outdoor air temperature..................... 16

11. Building management system snapshot of all zone temperatures at 08:19 a.m. on March 10, 2014.

12. Daily combined VRF unit power consumption with missing data (upper) and with missing data filled in (lower).

13. Pump speed (percentage of its full speed) and the coincidental temperature differential at the

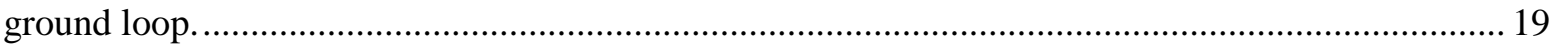

14. Daily power consumption of GS-VRF system and each end use ................................................. 20

15. Monthly power consumption of VRF units, indoor FCUs, and pumps.......................................... 21

16. Ground loop temperatures and the coincidental ambient temperatures......................................... 22

17. Ground loop heat transfer: (a) time series plot and (b) scatter plot compared with the outdoor

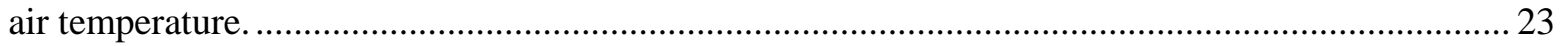

18. Estimated hourly cooling and heating outputs of the GS-VRF system. .........................................25

19. Monthly cooling load and efficiency of VRF units and GS-VRF system. .....................................25

20. Monthly heating load and efficiency of VRF units and the GS-VRF system.................................26

21. Monthly supply water temperature from the ground loop...................................................... 28

22. Three-dimensional rendering of the eQUEST model for the host building...................................2 29

23. Hourly heating and cooling loads (measured vs. simulated) versus ambient air temperature............ 30

24. Hourly GS-VRF system energy use (measured vs. simulated) versus ambient air temperature. ........30

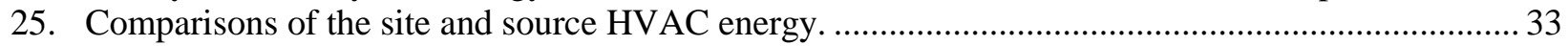

26. Comparisons of site energy end use between GS-VRF and two baseline systems............................33

27. Comparisons of source energy end use between GS-VRF and two baseline systems........................34

28. Summary of the costs and counts of maintenance requests for HVAC-related issues. ....................... 36

\section{LIST OF TABLES}

\section{Table}

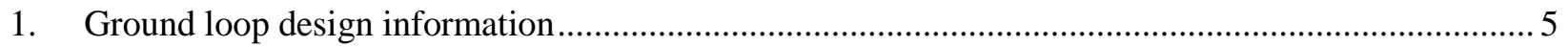

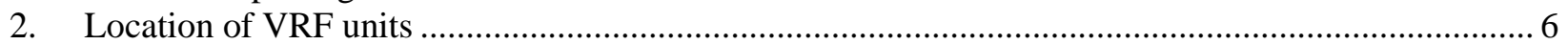

3. Location and size of VRF units and the number of associated BS boxes and FCUs.......................... 8

4. Oakland University GS-VRF system monitoring points on thermal loops ..................................... 11

5. Oakland University GS-VRF system monitoring points for power use of VRF units....................... 12

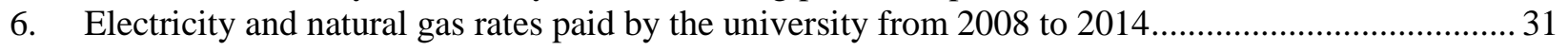




\begin{abstract}
High initial costs and lack of public awareness of ground-source heat pump (GSHP) technology are the two major barriers preventing rapid deployment of this energy-saving technology in the United States. Under the American Recovery and Reinvestment Act (ARRA), 26 GSHP projects have been competitively selected and carried out to demonstrate the benefits of GSHP systems and innovative technologies for cost reduction and/or performance improvement. This paper highlights the findings of a case study of one of the ARRA-funded GSHP demonstration projects, a ground-source variable refrigerant flow (GS-VRF) system installed at the Human Health Building at Oakland University in Rochester, Michigan. This case study is based on the analysis of measured performance data, maintenance records, construction costs, and simulations of the energy consumption of conventional central heating, ventilation, and air-conditioning (HVAC) systems providing the same level of space conditioning as the demonstrated GS-VRF system. The evaluated performance metrics include the energy efficiency of the heat pump equipment and the overall GS-VRF system, pumping performance, energy savings, carbon emission reductions, and cost-effectiveness of the GS-VRF system compared with conventional HVAC systems. This case study also identified opportunities for reducing uncertainties in the performance evaluation, improving the operational efficiency, and reducing the installed cost of similar GSHP systems in the future.
\end{abstract}





\section{INTRODUCTION}

\subsection{Background}

In 2009, 26 projects were competitively selected and funded with an American Recovery and Reinstatement Action (ARRA) grant to demonstrate innovative ground-source heat pump (GSHP) technologies. Oakland University in Rochester, Michigan, was one of 26 demonstration sites. The GSHP technology demonstrated at this site is a ground-source variable refrigerant flow (GS-VRF) system. This system is designed to provide space cooling and heating to a new $172,000 \mathrm{ft}^{2} \mathrm{Human}$ Health Building (HHB) on the Oakland University campus (Figure 1). The demonstrated GS-VRF system includes 256 vertical boreholes, two variable-speed loop pumps, 50 water-source Dakin variable refrigerant flow (VRF) units and three "GEO Heat" water-to-water heat pump units. The total installed cooling capacity is 440 tons.

The building construction was completed in 2012, and the building has been occupied and operated since then. Performance data from the GS-VRF system has been collected by Oakland University since September 2013.
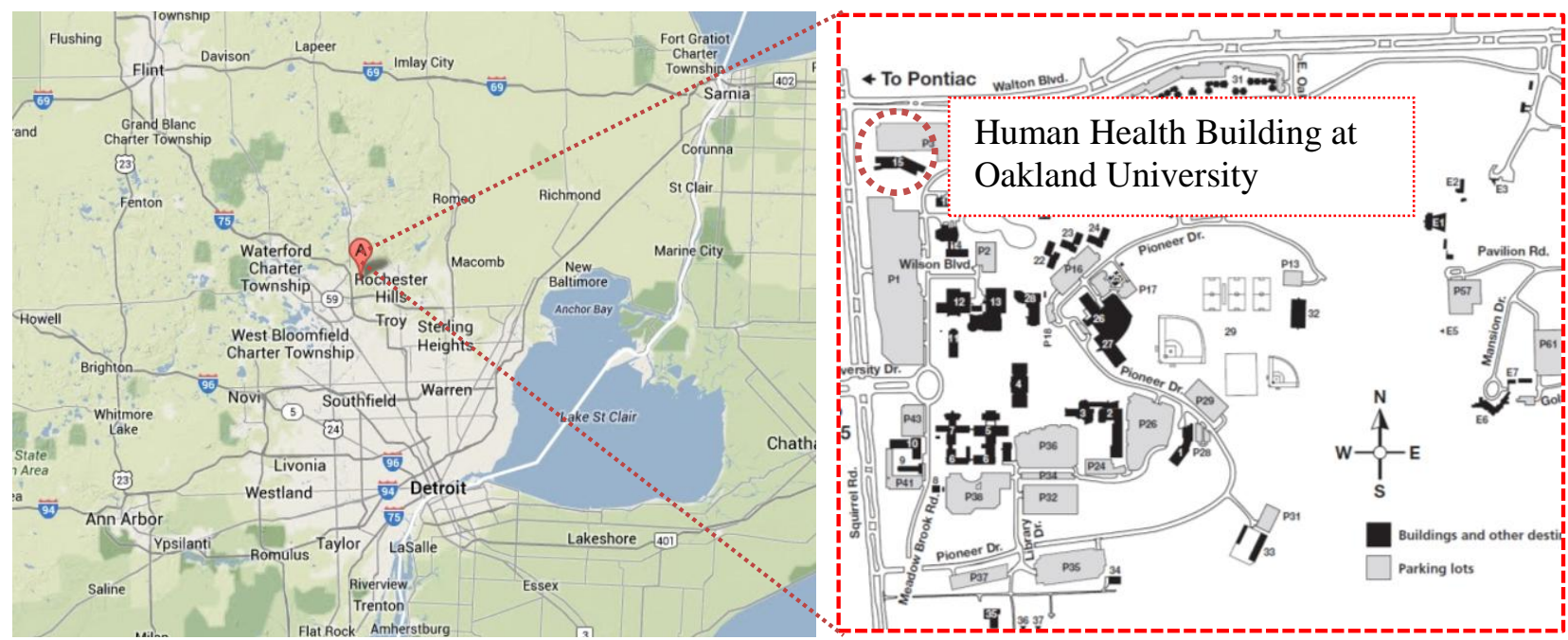

Figure 1. Geographic location of the GSHP demonstration site at Oakland University.

\subsection{Building and System Information}

Characteristic information about the building and the new GS-VRF system is introduced in the following sections.

\subsubsection{Building Information}

The $172,000 \mathrm{ft}^{2} \mathrm{HHB}$ at Oakland is a five-story building that includes a large auditorium, nine classrooms, a health clinic, teaching lab space, and faculty and administrative offices for two academic units on campus. It is the first LEED (Leadership in Energy and Environmental Design) Platinum building built in the state of Michigan.

The building cost around $\$ 62$ million to complete, including a $\$ 2.7$ million grant from US Department of Energy (DOE). The GS-VRF system makes the HBB independent of the central heating plant of the 
campus and eliminates the auxiliary cooling tower for the building. Since its opening in August 2012, the building has operated well with fewer complaints compared with other buildings (180 per year instead of 300 per year on average), and the system performance has been monitored since August 2013.

Figure 2, Figure 3, and Figure 4 show the HHB from the south, west, and east views, respectively.

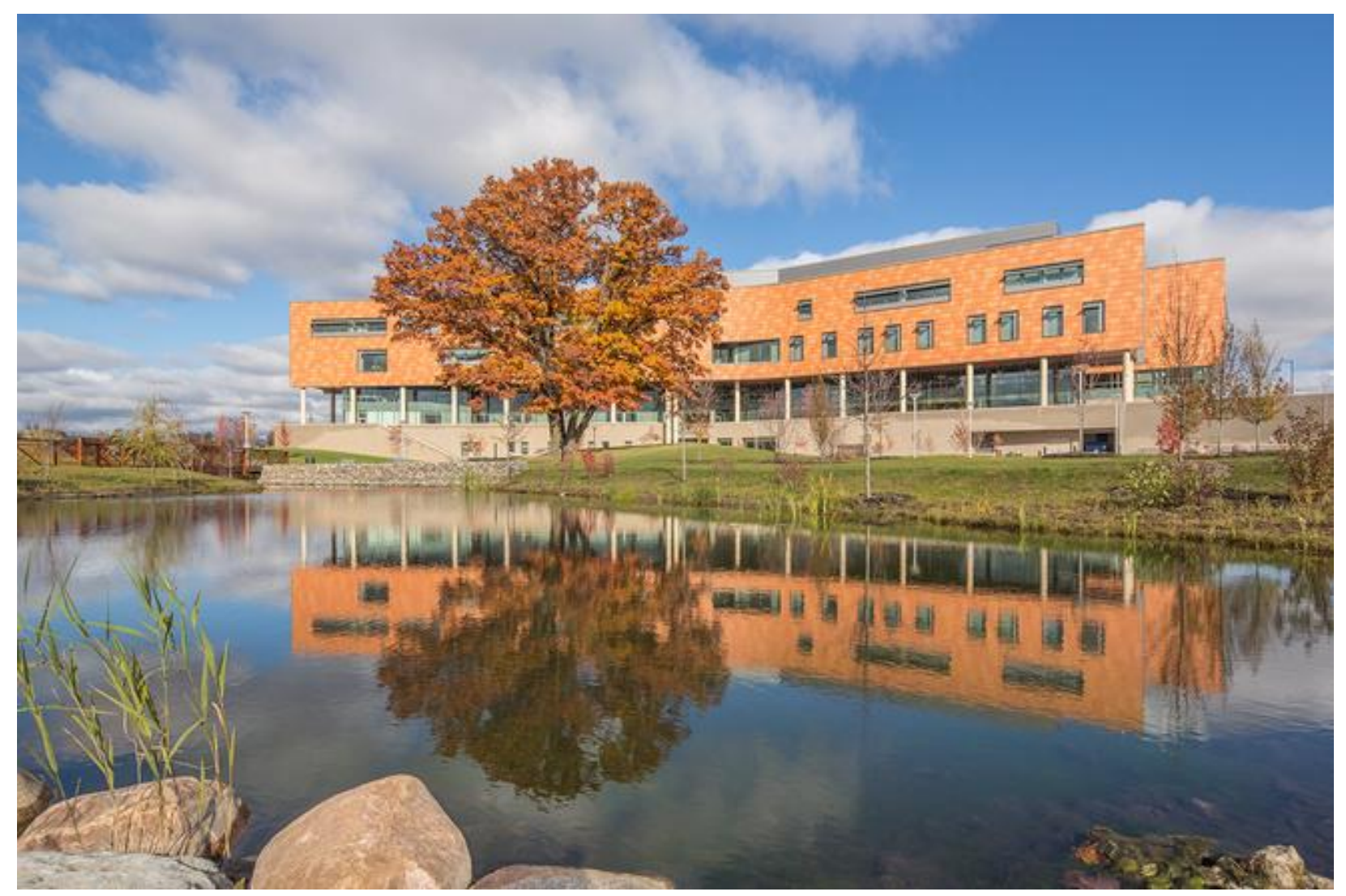

Figure 2. Human Health Building from the south view.

In addition to the GS-VRF system, the HBB also implemented following mechanical systems:

1. A 47,000 cfm dedicated outdoor air system (DOAS) provides ventilation air for the building. The DOAS is equipped with heat recovery wheels to precondition outdoor air using the building general exhaust. During warm and humid weather, desiccant wheels are used to dry incoming outdoor air. The heat collected from a solar system is used to regenerate the desiccant and to warm the outdoor air along with other heating devices (a natural gas-fired boiler and the "GEO Heat" water-to-water heat pumps). Chilled water produced by the water-to-water heat pumps is used to cool the outdoor air.

2. Solar thermal collectors on the roof provide most of the required heat for ventilation, entrance vestibules and lobbies, pool heating, domestic hot water (DHW), and a sidewalk snow-melting system. In the summer, the collectors are used as a heat source to regenerate the desiccant in the DOAS. Four 25,000 gallon underground tanks allow any excess heat collected to be stored until needed. 


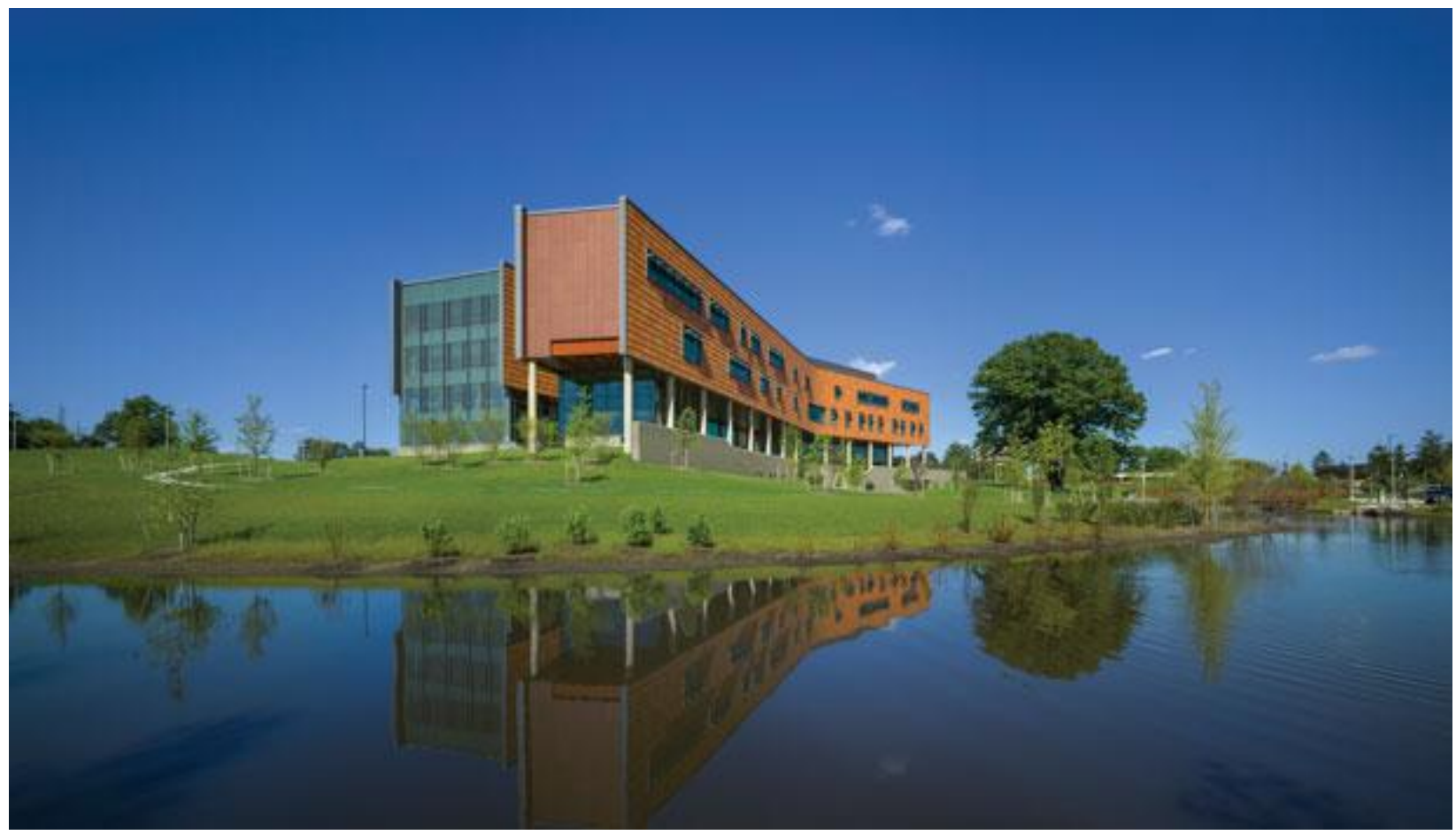

Figure 3. Human Health Building from the west view.

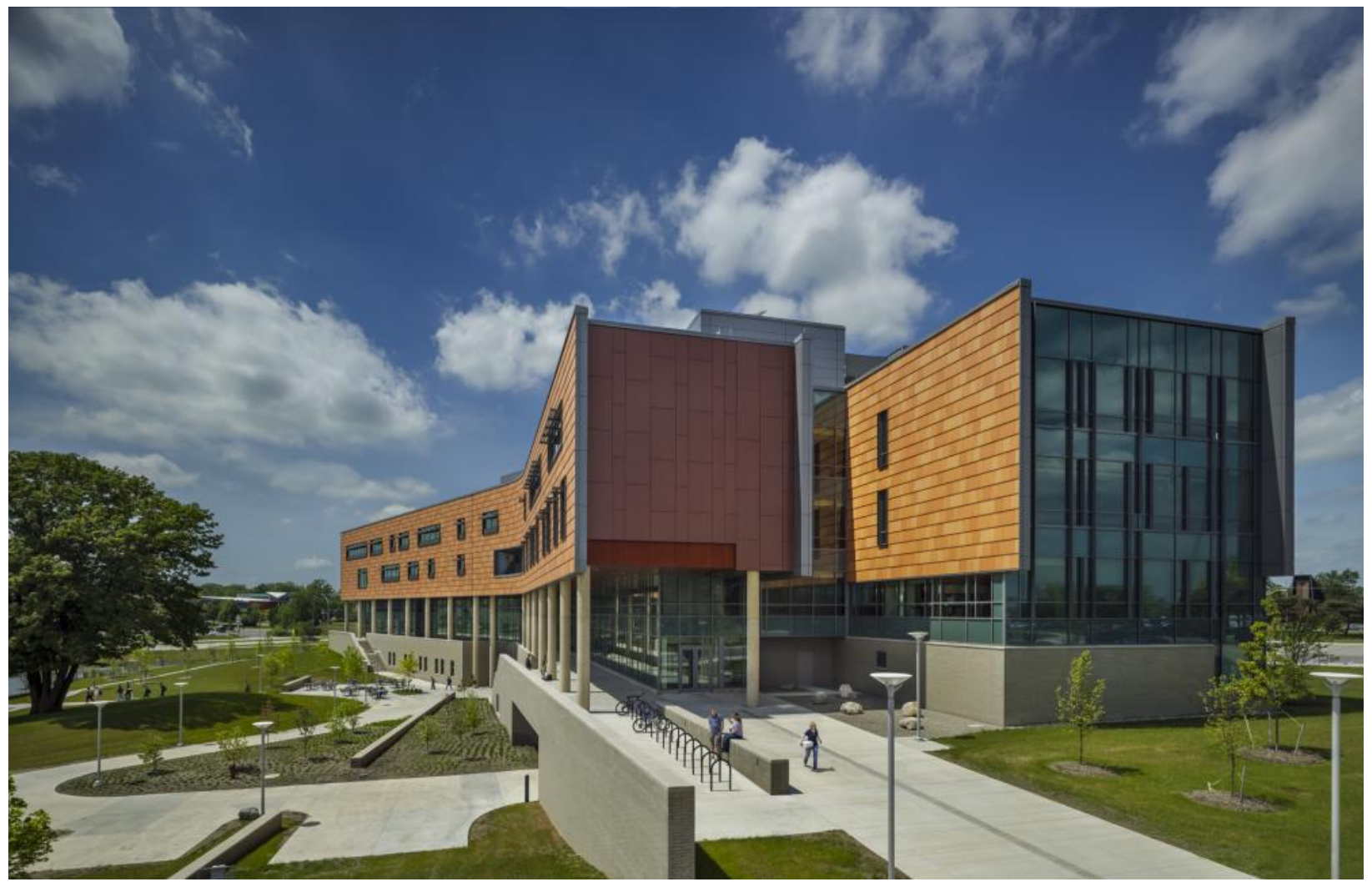

Figure 4. Human Health Building from the east view. 


\subsubsection{Description of the Demonstrated GS-VRF System}

The main heating, ventilation, and air-conditioning (HVAC) system for the building is a GS-VRF system. The outdoor air ventilation of the building is provided by a DOAS, which uses a ground source heat pump/ chiller to cool the outdoor air. Figure 5 presents a schematic for the GS-VRF system (including the DOAS) and monitored data points. As shown in Figure 5, the ground (or source) loop includes the following control options: heat can be added to the source loop from the hot water loop (via heat exchanger HX-3) when the source loop temperature falls below $51^{\circ} \mathrm{F}$. Water from the source loop can be directly injected into the chilled water loop for direct use in the DOAS (via HX-2) when its temperature falls below $60^{\circ} \mathrm{F}$ (i.e., the economizer cooling mode).

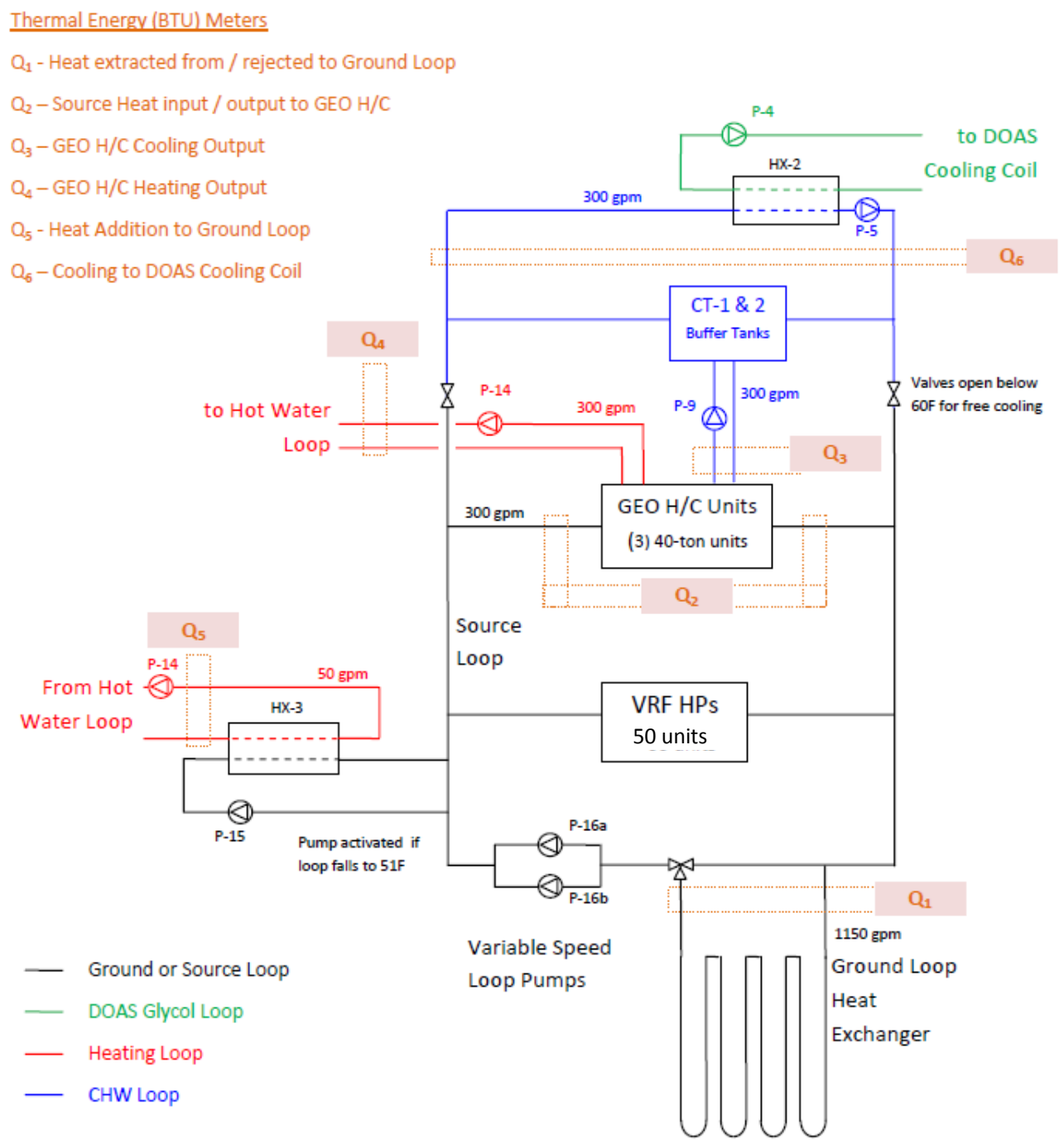

Figure 5. GS-VRF system schematic with monitored data points (CDH 2013). 


\subsubsection{Ground Heat Exchanger}

The ground loop well field includes 256 bores that are $320 \mathrm{ft}$ deep, for a total of 81,920 bore-feet and a total piping length of $163,840 \mathrm{ft}$. The bore field is divided into two adjacent grids, one $13 \times 17$ and the other $5 \times 7$. All bores are spaced on $25 \mathrm{ft}$ centers. Based on the 440 ton installed heat pump capacity, the loop is sized for 186 bore-feet/ton. The wells are divided into 20 parallel circuits. Circulation in the ground loop system is provided by two redundant $60 \mathrm{hp}$ variable-frequency drive (VFD) pressurecontrolled pumps (Figure 5: P-16A, P-16B) with a three-way valve to bypass the ground loop as needed. The pump speed modulates to maintain the loop pressure. Table 1 provides some details of the ground loop field.

Table 1. Ground loop design information

\begin{tabular}{|l|l|}
\hline HEAT EXCHANGER INFORMATION & \\
\hline Configuration & Vertical Closed Loop \\
\hline Borehole Quantity & 256 \\
\hline Borehole Depth & 320 feet \\
\hline Borehole Separation & 25 feet \\
\hline Number of Circuits & 20 \\
\hline Thermal Conductivity * & 1.23 BTU / (hr-ft-deg F) \\
\hline Soil Diffusivity & 0.83 foot2 / day \\
\hline Undisturbed Ground Temperature $*$ & 53.0 deg F \\
\hline GHX Pressure Drop & 42 feet of head \\
\hline & \\
\hline FLUID INFORMATION & \\
\hline Total Flow & 1,225 GPM \\
\hline Fluid & Water only \\
\hline Minimum HP Unit Inlet Fluid Temp & 40 deg F \\
\hline Maximum HP Unit Inlet Fluid Temp & 90 deg F \\
\hline & \\
\hline GROUT INFORMATION & \\
\hline Grout Type & Thermally Enhanced Bentonite \\
\hline Minimum Thermal Conductivity & 0.88 BTU / (hr-ft-deg F) \\
\hline
\end{tabular}

\subsubsection{VRF System}

The water-cooled VRF units are located in ten different mechanical closets in the building (located in both east and west sides at each of the five floors). There are a total of 50 Dakin RWEYQ series units that are either 6 or 7 tons. Each closet has four to six units ( 24 to 42 tons), and up to three individual units are connected in parallel to form a bank with a larger capacity. The number of VRF units and the total capacity (cooling ton) in each closet are listed in Table 2. Figure 6 shows one of the mechanical closets, which contains five VRF units. The total nominal capacity of the 50 units is 320 tons. Four of the units (25 tons) are cooling-only units (see Table 3 for "Type: AC"). The remaining units are heat recovery units (see Table 3 for "Type: HR") that can provide heating and cooling simultaneously at different zones. According to the design document, these VRF units are able to operate only when the entering water temperatures are above $50^{\circ} \mathrm{F}$. 
Table 2. Location of VRF units

\begin{tabular}{ccc}
\hline Closet & $\begin{array}{c}\text { HP size } \\
\text { (tons) }\end{array}$ & $\begin{array}{c}\text { Unit } \\
\text { count }\end{array}$ \\
\hline 1st Floor West & 24 & 4 \\
1st Floor East & 24 & 4 \\
2nd Floor West & 32 & 5 \\
2nd Floor East & 32 & 5 \\
3rd Floor West & 24 & 4 \\
3rd Floor East & 37 & 6 \\
4th Floor West & 28 & 4 \\
4th Floor East & 42 & 6 \\
5th Floor West & 41 & 6 \\
5th Floor East & 36 & 6 \\
Total & 320 & 50 \\
\hline
\end{tabular}

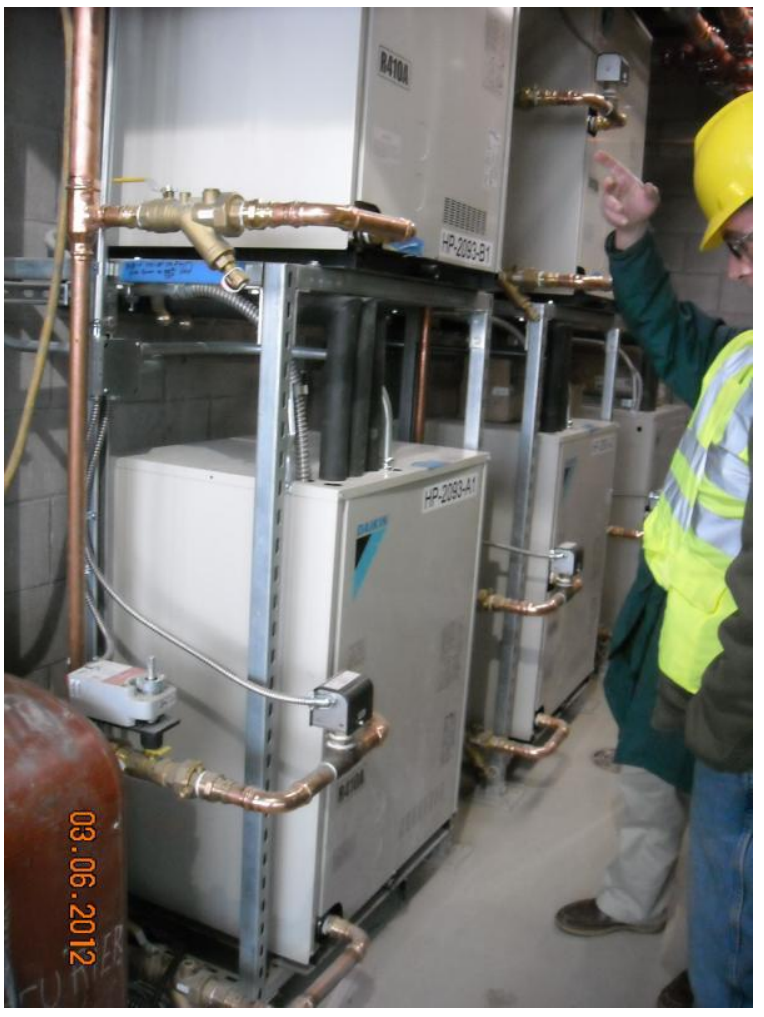

Figure 6. Photo of one mechanical closet containing five VRF units.

In addition to the water-cooled VRF units, the VRF system has a total of 189 fan coil units (FCUs) with 320 tons connected capacity and 107 branch selector (BS) boxes. Up to three FCUs are connected to each BS box, which route refrigerant in the form of either hot gas (for heating) or low-temperature liquid (for cooling) to the FCUs connected to it. All the FCUs connected to the same BS box operate in the same 
heating or cooling mode. Each VRF unit can serve up to 10 BS boxes. Table 3 shows the grouping of the VRF units as well as the number of BS boxes and FCUs associated with each VRF unit. As an example, Figure 7 shows the grouping and layout of the FCUs on the second floor of the west wing of the building. Also as can be seen in Figure 7, conditioned outdoor air from the DOAS is ducted into a mixing box attached to the return air side of each FCU to provide outdoor air ventilation in the zones served by the FCU. The four cooling-only units are not equipped with BS boxes (see Table 3 for "Type: AC").

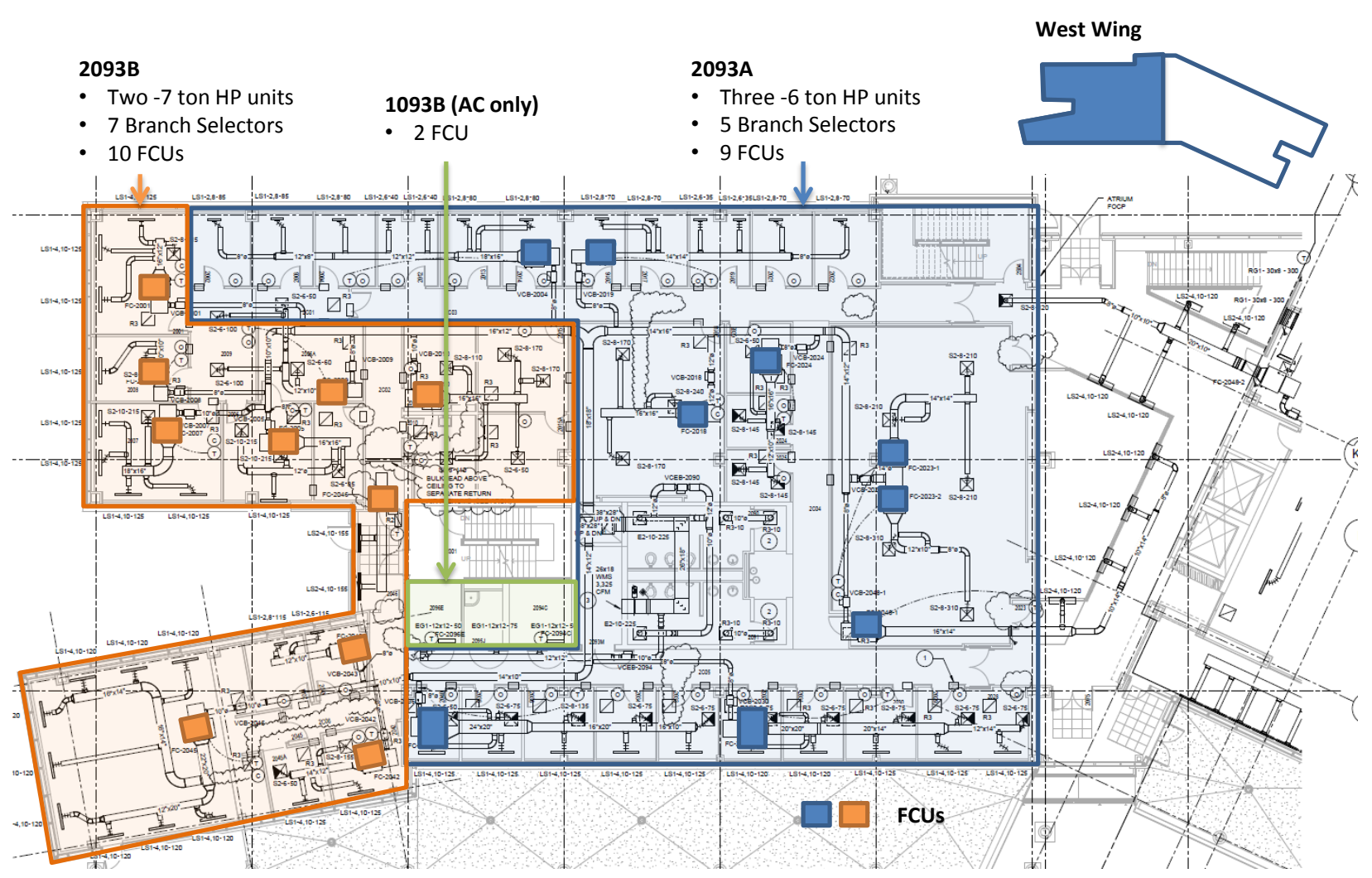

Figure 7. Layout of the FCUs for the west wing of the second floor.

All the VRF units in the west side of the building are controlled by an "Intelligent Touch" controller provided by the VRF manufacturer, and all the VRF units in the east side of the building are controlled by another "Intelligent Touch" controller.

\subsubsection{Dedicated Outdoor Air System}

Two separate DOASs continuously condition outdoor air year round and deliver conditioned outdoor air to all the FCUs. The total design flow rate of the two DOASs is $47,000 \mathrm{cfm}$, but the actual outdoor air flow rate varies based on demand. The outdoor air flow provided to most of the small zones is modulated by the outdoor air damper at the mixing box of the FCU serving the zone. The damper is controlled based on an occupancy sensor in the zone. Outdoor air flow in larger zones is maintained at a minimum rate and is increased when the $\mathrm{CO}_{2}$ concentration in the zone rises above certain level. A variable-speed supply fan of the DOAS modulates to maintain a specified static pressure at the supply duct leaving the DOAS. A variable-speed exhaust fan varies the exhaust air flow to maintain a slightly positive pressurization in the building. The DOAS was originally designed to provide $55^{\circ} \mathrm{F}$ supply air, but it is currently operated to provide $70^{\circ} \mathrm{F}$ supply air. 
Table 3. Location and size of VRF units and the number of associated BS boxes and FCUs

\begin{tabular}{|c|c|c|c|c|c|c|}
\hline Location & System Tag & Unit & Type & AC Size (ton) & Branch Selector Boxes & FCUs \\
\hline \multirow{4}{*}{ 1st Flr West } & \multirow{3}{*}{$1093 \mathrm{~A}$} & RWEYQ72PTJU-HR & $\mathrm{HR}$ & 6 & \multirow{3}{*}{10} & \multirow{3}{*}{15} \\
\hline & & RWEYQ72PTJU-HR & $\mathrm{HR}$ & 6 & & \\
\hline & & RWEYQ72PTJU-HR & $\mathrm{HR}$ & 6 & & \\
\hline & 1093B & RWEYQ72PTJU & $\mathrm{AC}$ & 6 & 0 & 6 \\
\hline \multirow{4}{*}{ 1st Flr East } & \multirow{3}{*}{$1193 A$} & RWEYQ72PTJU-HR & $\mathrm{HR}$ & 6 & \multirow{3}{*}{10} & \multirow{3}{*}{10} \\
\hline & & RWEYQ72PTJU-HR & $\mathrm{HR}$ & 6 & & \\
\hline & & RWEYQ72PTJU-HR & $\mathrm{HR}$ & 6 & & \\
\hline & 1193B & RWEYQ72PTJU & $\mathrm{AC}$ & 6 & 0 & 5 \\
\hline \multirow{5}{*}{ 2nd Flr West } & \multirow{3}{*}{$2093 \mathrm{~A}$} & RWEYQ72PTJU-HR & $\mathrm{HR}$ & 6 & \multirow{3}{*}{5} & \multirow{3}{*}{9} \\
\hline & & RWEYQ72PTJU-HR & $\mathrm{HR}$ & 6 & & \\
\hline & & RWEYQ72PTJU-HR & $\mathrm{HR}$ & 6 & & \\
\hline & \multirow{2}{*}{ 2093B } & RWEYQ84PTJU-HR & $\mathrm{HR}$ & 7 & \multirow{2}{*}{7} & \multirow{2}{*}{10} \\
\hline & & RWEYQ84PTJU-HR & $\mathrm{HR}$ & 7 & & \\
\hline \multirow{5}{*}{ 2nd Flr East } & \multirow{3}{*}{$2193 A$} & RWEYQ72PTJU-HR & $\mathrm{HR}$ & 6 & \multirow{3}{*}{8} & \multirow{3}{*}{10} \\
\hline & & RWEYQ72PTJU-HR & $\mathrm{HR}$ & 6 & & \\
\hline & & RWEYQ72PTJU-HR & $\mathrm{HR}$ & 6 & & \\
\hline & \multirow{2}{*}{ 2193B } & RWEYQ84PTJU-HR & $\mathrm{HR}$ & 7 & 1 & 1 \\
\hline & & RWEYQ84PTJU-HR & $\mathrm{HR}$ & 7 & 4 & 4 \\
\hline & & RWEYQ72PTJU-HR & $\mathrm{HR}$ & 6 & & \\
\hline $2 \mathrm{rd}$ Flr $1 \mathrm{coc}$ & 3093A & RWEYQ72PTJU-HR & $\mathrm{HR}$ & 6 & 5 & 9 \\
\hline sra rir west & $3093 \mathrm{R}$ & RWEYQ72PTJU-HR & $\mathrm{HR}$ & 6 & 8 & 10 \\
\hline & $3093 \mathrm{~B}$ & RWEYQ72PTJU-HR & $\mathrm{HR}$ & 6 & 8 & 10 \\
\hline & & RWEYQ72PTJU-HR & $\mathrm{HR}$ & 6 & & \\
\hline & $3193 \mathrm{~A}$ & RWEYQ72PTJU-HR & $\mathrm{HR}$ & 6 & 6 & 14 \\
\hline & & RWEYQ72PTJU-HR & $\mathrm{HR}$ & 6 & & \\
\hline 3rd FIr East & $3193 B$ & RWEYQ72PTJU-HR & $\mathrm{HR}$ & 6 & 4 & 10 \\
\hline & 3193В & RWEYQ72PTJU-HR & $\mathrm{HR}$ & 6 & 4 & 10 \\
\hline & $3193 C$ & RWEYQ84PTJU & $\mathrm{AC}$ & 7 & 0 & 8 \\
\hline & 40934 & RWEYQ84PTJU-HR & $\mathrm{HR}$ & 7 & 4 & 5 \\
\hline Ath Flr Wlect & 4093A & RWEYQ84PTJU-HR & $\mathrm{HR}$ & 7 & 4 & 3 \\
\hline 4th Fir vivest & $4093 B$ & RWEYQ84PTJU-HR & $\mathrm{HR}$ & 7 & 5 & 9 \\
\hline & $4093 B$ & RWEYQ84PTJU-HR & $\mathrm{HR}$ & 7 & 5 & 9 \\
\hline & & RWEYQ84PTJU-HR & $\mathrm{HR}$ & 7 & & \\
\hline & $4193 \mathrm{~A}$ & RWEYQ84PTJU-HR & $\mathrm{HR}$ & 7 & 5 & 10 \\
\hline$A$ th Flr Fact & & RWEYQ84PTJU-HR & $\mathrm{HR}$ & 7 & & \\
\hline 4til ril Edst & & RWEYQ84PTJU-HR & $\mathrm{HR}$ & 7 & & \\
\hline & 4193B & RWEYQ84PTJU-HR & $\mathrm{HR}$ & 7 & 7 & 10 \\
\hline & & RWEYQ84PTJU-HR & $\mathrm{HR}$ & 7 & & \\
\hline & & RWEYQ84PTJU-HR & $\mathrm{HR}$ & 7 & & \\
\hline & $5093 \mathrm{~A}$ & RWEYQ84PTJU-HR & $\mathrm{HR}$ & 7 & 5 & 8 \\
\hline 5th Flr West & & RWEYQ84PTJU-HR & $\mathrm{HR}$ & 7 & & \\
\hline sin ril valst & $5093 \mathrm{~B}$ & RWEYQ84PTJU-HR & $\mathrm{HR}$ & 7 & 3 & 5 \\
\hline & 5093B & RWEYQ84PTJU-HR & $\mathrm{HR}$ & 7 & 3 & 5 \\
\hline & $5093 C$ & RWEYQ72PTJU & $\mathrm{AC}$ & 6 & 0 & 6 \\
\hline & & RWEYQ72PTJU-HR & $\mathrm{HR}$ & 6 & & \\
\hline & $5193 A$ & RWEYQ72PTJU-HR & $\mathrm{HR}$ & 6 & 7 & 10 \\
\hline 5 th Flr Eact & & RWEYQ72PTJU-HR & $\mathrm{HR}$ & 6 & & \\
\hline Stn ril Edst & & RWEYQ72PTJU-HR & $\mathrm{HR}$ & 6 & & \\
\hline & 5193B & RWEYQ72PTJU-HR & $\mathrm{HR}$ & 6 & 4 & 6 \\
\hline & & RWEYQ72PTJU-HR & $\mathrm{HR}$ & 6 & & \\
\hline Total & & & & 320 & 107 & 189 \\
\hline
\end{tabular}

The DOAS unit includes a heat recovery wheel as well as post-heating and -cooling coils. Hot water from the main hot water loop of the building provides heat to the DOAS, and the ground source heat pump/chiller provides chilled water to cool the outdoor air. The DOAS also has a desiccant wheel for dehumidification. The desiccant wheel is regenerated using the heat from the main hot water loop. Since 
the desiccant wheel provides dehumidification, the chilled water supply temperature is increased to $60^{\circ} \mathrm{F}$ so that only sensible cooling is provided by the cooling coils.

\subsubsection{Ground-Source Heat Pump/Chiller}

The ground source heat pump/chiller has three 30 ton (at $45^{\circ} \mathrm{F}$ chilled water supply temperature) modules connected in parallel so that they are plumbed as one single unit (Figure 8). Since the chilled water supply temperature is set at $60^{\circ} \mathrm{F}$ for providing only sensible cooling at the DOAS, each module actually supplies 40 tons of cooling capacity.

The chiller feeds chilled water in the storage/buffer tanks (CT-1 and CT-2 as shown in Figure 5). The chilled water is pumped from the tanks to HX-2, which cools the glycol-chilled water loop of the DOAS. The system is configured so that the water from the ground loop can be used directly to feed the storage/buffer tanks when it is below $60^{\circ} \mathrm{F}$. When heating in needed, the $130^{\circ} \mathrm{F}$ water from the condenser of the chiller is added to the main hot water loop instead of being rejected to the ground loop.

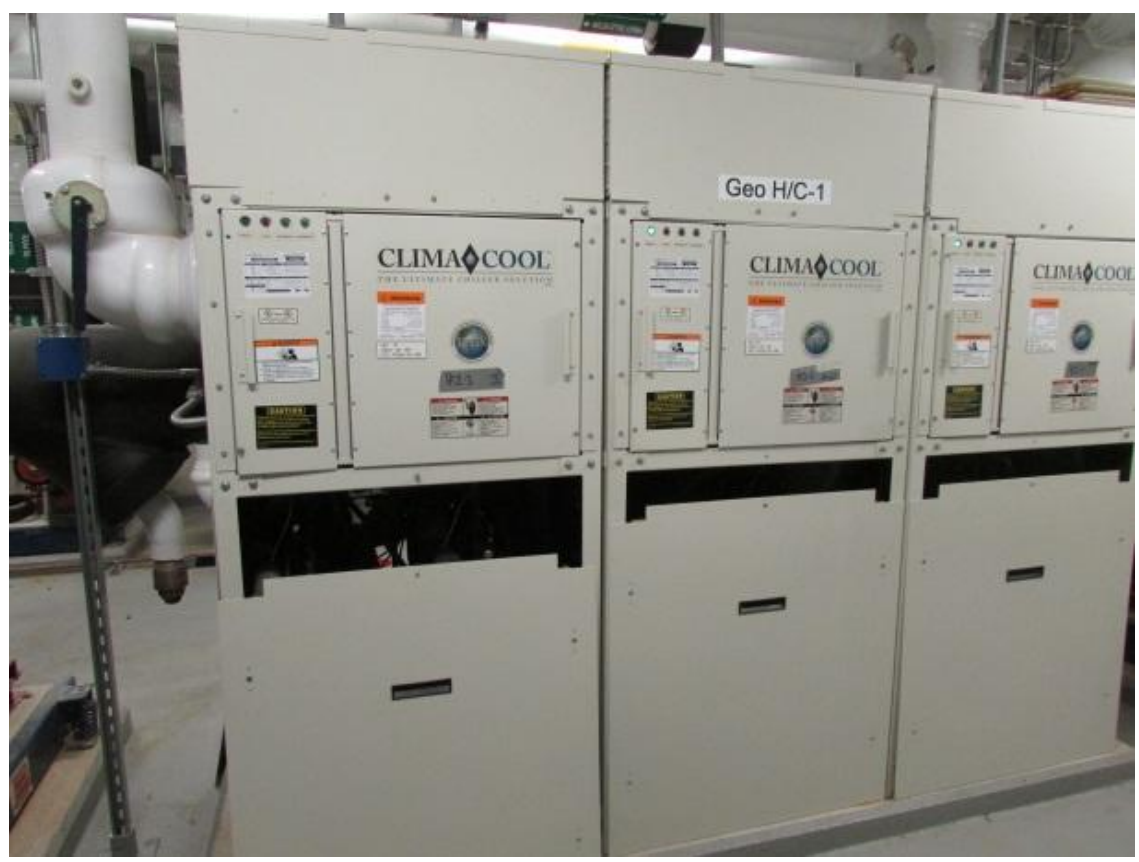

Figure 8. Photo of the installed ground-source heat pump/chiller.

\subsubsection{Other Equipment}

The building also has the following heating equipment/system. Since this equipment is not directly related to the GS-VRF system, its performance was neither monitored nor analyzed in this study.

- Hot water storage tanks: There are four 25,000 gallon underground hot water storage tanks. This storage system is connected to the solar collector loop via a heat exchanger (HX-4).

- Unit heaters: There are 3 hot water unit heaters and 12 hot water cabinet unit heaters. The 15 hot water unit heaters (mostly providing heating for staircases) are served by the main hot water loop. There are also two small electric unit heaters in the building. 
- DHW heater: The DHW heater provides $120^{\circ} \mathrm{F}$ hot water through a DHW heat exchanger (DHW-1) in the main hot water loop.

- Hot water boiler: The hot water loop can be heated by an Aerco $50 \mathrm{gpm}, 1000 \mathrm{kBtu} / \mathrm{h}$ boiler that provides $130^{\circ} \mathrm{F}$ water.

- Pool heating: The pool is heated by the main hot water loop via HX-6.

- Solar heating system: This system includes $6458 \mathrm{ft}^{2}\left(600 \mathrm{~m}^{2}\right)$ of solar collectors as well as an 18 ton dry cooler (presumably for heat rejection if the storage gets too warm). The solar loop is filled with a $50 \%$ glycol solution.

- Snow melting system: This system uses heat from the main hot water loop and moves it through a hydronic piping system embedded in the concrete pavement of the sidewalk to melt snow on the sidewalk. 


\section{MONITORING AND ANALYSIS PLAN}

\subsection{Data Monitoring Plan}

Performance data of the demonstrated system is collected by the grantee through the existing building control system. The monitored points were selected to focus primarily on the GS-VRF system.

Figure 5 shows the location of the thermal energy (Btu) meters that were installed to measure the key energy flows in the system. Each energy meter uses a Siemens Controlatron ultrasonic flow meter integrated with temperature sensors to record the rate of thermal energy transfer (see data in Table 4). Power transducers are used to measure the combined power of all the VRF units in each mechanical closet (see data in Table 5).

All data are collected at 15 minute intervals. Temperatures and flows are averaged values. The kilowatt readings from the power meters are instantaneous, while kilowatt-hours are cumulative readings. The data are transferred weekly to a server and stored in column-oriented, time-stamped, comma-delimited files (CSV format). One file is provided for each data point.

Table 4. Oakland University GS-VRF system monitoring points on thermal loops

\begin{tabular}{|c|c|c|c|c|}
\hline Description & \begin{tabular}{|l|} 
CDH Data \\
Point Name
\end{tabular} & Tridium Raw Data File Name & $\begin{array}{l}\text { Eng } \\
\text { Units }\end{array}$ & Dwg ID \\
\hline \multirow{3}{*}{$\begin{array}{l}\text { BTU Meter } 1 \\
\text { (Ground Loop) }\end{array}$} & FG & Geothermal_Flow_Rate & gpm & WELL-F \\
\hline & TGR & Geothermal_Return_Temp & $\mathrm{F}$ & T-40 \\
\hline & TGS & Geothermal_Supply_Temp & $\mathrm{F}$ & T-41 \\
\hline \multirow{3}{*}{$\begin{array}{c}\text { BTU Meter } 6 \\
\text { (CHW to DOAS) }\end{array}$} & FX2C & HX_2_Chilled_Water_Flow_Rate & gpm & P5-F1 \\
\hline & TX2CR & HX_2_Chilled_Return_Temp & $\mathrm{F}$ & $\mathrm{T}-8$ \\
\hline & TX2CS & HX_2_Chilled_Water_Supply_Temp & $\mathrm{F}$ & T-9 \\
\hline \multirow{3}{*}{$\begin{array}{c}\text { BTU Meter } 3 \\
\text { (CHW from H/C } \\
\text { Unit) }\end{array}$} & $\mathrm{FCHC}$ & Heater_Chiller_Chilled_Water_Flow_Rate & gpm & P9-F \\
\hline & TCHCR & Heater_Chiller_Chilled_Water_Return_Temp & $\mathrm{F}$ & T-28 \\
\hline & TCHCS & Heater_Chiller_Chilled_Water_Supply_Temp & $\mathrm{F}$ & T-29 \\
\hline \multirow{3}{*}{$\begin{array}{c}\text { BTU Meter } 4 \\
\text { (heat from } \mathrm{H} / \mathrm{C} \\
\text { Unit) }\end{array}$} & $\mathrm{FCHH}$ & Heater_Chiller_Heating_Water_Flow_Rate & gpm & P8-F \\
\hline & TCHHR & Heater_Chiller_Heating_Water_Return_Temp & $\mathrm{F}$ & T-26 \\
\hline & TCHHS & Heater_Chiller_Heating_Water_Supply_Temp & $\mathrm{F}$ & $\mathrm{T}-27$ \\
\hline \multirow{3}{*}{$\begin{array}{c}\text { BTU Meter } 2 \\
\text { (Source to H/C } \\
\text { Unit) }\end{array}$} & FCHS & Heater_Chiller_Source_Water_Flow_Rate & gpm & GEO-F1 \\
\hline & TCHSR & Heater_Chiller_Source_Water_Return_Temp & $F$ & $\mathrm{~T}-31$ \\
\hline & TCHSS & Heater_Chiller_Source_Water_Supply_Temp & $\mathrm{F}$ & $\mathrm{T}-30$ \\
\hline \multirow{4}{*}{$\begin{array}{c}\text { Pump 16A/16B } \\
\text { Status }\end{array}$} & SP16A & P16A_Source_Water_Pump_Speed_Hz & $\mathrm{Hz}$ & \\
\hline & PER_P16A & P16A_Source_Water_Pump_Speed_Percent & $\%$ & \\
\hline & SP16B & P16B_Source_Water_Pump_Speed_Hz & $\mathrm{Hz}$ & \\
\hline & PER_P16B & P16B_Source_Water_Pump_Speed_Percent & $\%$ & \\
\hline \multirow{3}{*}{$\begin{array}{c}\text { BTU Meter } 5 \\
\text { (Heat Addition } \\
\text { to Source Loop) }\end{array}$} & FS & Source_Water_Flow_Rate & gpm & $\mathrm{HW}-\mathrm{F}$ \\
\hline & TSR & Source_Water_Return_Temp & $\mathrm{F}$ & T-34 \\
\hline & TSS & Source_Water_Supply_Temp & $\mathrm{F}$ & T-35 \\
\hline W Underground & TAO & Ambient Temperature (from airport) & $F$ & \\
\hline
\end{tabular}


Table 5. Oakland University GS-VRF system monitoring points for power use of VRF units

\begin{tabular}{|c|c|c|c|}
\hline Location & Data Point Name & Raw Data File Name & Units \\
\hline \multirow{2}{*}{ 1st Floor East } & WE1_KW & 1st_Floor_East_Heat_Pumps_KW & $\mathrm{kW}$ \\
\hline & WE1 & 1st_Floor_East_Heat_Pumps_KWH & $\mathrm{kWh}$ \\
\hline \multirow{2}{*}{ 1st Floor West } & WW1_KW & 1st_Floor_West_Heat_Pumps_KW & kW \\
\hline & WW1 & 1st_Floor_West_Heat_Pumps_KWH & $\mathrm{kWh}$ \\
\hline \multirow{2}{*}{ 2nd Floor East } & WE2_KW & 2nd_Floor_East_Heat_Pumps_KW & $\mathrm{kW}$ \\
\hline & WE2 & 2nd_Floor_East_Heat_Pumps_KWH & kWh \\
\hline \multirow{2}{*}{ 2nd Floor West } & WW2_KW & 2nd_Floor_West_Heat_Pumps_KW & $\mathrm{kW}$ \\
\hline & WW2 & 2nd_Floor_West_Heat_Pumps_KWH & $\mathrm{kWh}$ \\
\hline \multirow{2}{*}{ 3rd Floor East } & WE3_KW & 3rd_Floor_East_Heat_Pumps_KW & kW \\
\hline & WE3 & 3rd_Floor_East_Heat_Pumps_KWH & $\mathrm{kWh}$ \\
\hline \multirow{2}{*}{ 3rd Floor West } & WW3_KW & 3rd_Floor_West_Heat_Pumps_KW & $\mathrm{kW}$ \\
\hline & WW3 & 3rd_Floor_West_Heat_Pumps_KWH & kWh \\
\hline \multirow{2}{*}{ 4th Floor East } & WE4_KW & 4th_Floor_East_Heat_Pumps_KW & kW \\
\hline & WE4 & 4th_Floor_East_Heat_Pumps_KWH & kWh \\
\hline \multirow{2}{*}{ 4th Floor West } & WW4_KW & 4th_Floor_West_Heat_Pumps_KW & $\mathrm{kW}$ \\
\hline & WW4 & 4th_Floor_West_Heat_Pumps_KWH & $\mathrm{kWh}$ \\
\hline \multirow{2}{*}{ 5th Floor East } & WE5_KW & 5th_Floor_East_Heat_Pumps_KW & $\mathrm{kW}$ \\
\hline & WE5 & 5th_Floor_East_Heat_Pumps_KWH & $\mathrm{kWh}$ \\
\hline \multirow{2}{*}{ 5th Floor West } & WW5_KW & 5th_Floor_West_Heat_Pumps_KW & kW \\
\hline & WW5 & 5th_Floor_West_Heat_Pumps_KWH & kWh \\
\hline
\end{tabular}

\subsection{Data Analysis Plan}

Based on measured performance data and other relevant information, this case study evaluates performance metrics, including the energy efficiency of the GS-VRF system, electric end uses of all major equipment of the GS-VRF system, benefits achieved by the GS-VRF system (e.g., energy and cost savings, carbon emission reductions) compared with conventional HVAC systems, and the costeffectiveness of the demonstrated GS-VRF installation.

From the collected data, heat transfer rates in each thermal loop shown in Figure 5 can be determined with Eq. (1).

$$
\mathbf{Q i}=\mathbf{K} \times \mathbf{F i} \times(\mathbf{T i S}-\mathbf{T i R}) / 1000,
$$

where

Qi $=$ heat transfer rate $(\mathrm{kBtu} / \mathrm{h})$,

$\mathbf{F i}=$ loop i flow rate $(\mathrm{gpm})$,

TiS $=$ loop i supply temperature $\left({ }^{\circ} \mathrm{F}\right)$,

$\mathbf{T i R}=$ loop i return temperature $\left({ }^{\circ} \mathrm{F}\right)$,

$\mathrm{K}=$ fluid factor.

The total load on the ground loop is given by $\mathbf{Q}_{1}$ and the thermal load imposed on the ground loop by the GSHP chiller is given by $\mathbf{Q}_{2}$. The thermal load imposed on the ground loop by the VRF units alone 
$\left(\mathrm{QR}_{\mathrm{VRF}}\right)$ can be determined with Eq. (2). The power consumption of the VRF units $\left(\mathrm{KW}_{\mathrm{VRF}}\right)$ can be determined with Eq. (3).

$$
\begin{aligned}
\mathrm{QR}_{\mathrm{VRF}} & =\mathbf{Q}_{\mathbf{1}}-\mathbf{Q}_{\mathbf{2}} \\
\mathrm{KW}_{\mathrm{VRF}} & =\Sigma \mathrm{KWi},
\end{aligned}
$$

where $\mathrm{KW}$ is the measured power consumption of all the VRF units in a mechanical closet and $\mathrm{i}=1$ to 10 (for the 10 mechanical closets)

The cooling and heating provided by the VRF units (Q_VRF_Cooling and Q_VRF_Heating) are approximately calculated with Eqs. (4) and (5), respectively.

If $\mathrm{QR}_{\mathrm{VRF}}<$ zero (rejecting heat to the ground loop):

$$
\text { Q_VRF_Cooling }=\text { EER }(T G S) \times \mathrm{KW}_{\mathrm{VRF}} \text {. }
$$

If $\mathrm{QR}_{\mathrm{VRF}}>$ zero (extracting heat from the ground loop):

$$
\text { Q_VRF_Heating }=\mathrm{COP}(\mathrm{TGS}) \times \mathrm{KW}_{\mathrm{VRF}} \times 3.413 \text {, }
$$

where EER and COP are the average cooling and heating efficiencies of all the VRF units combined, which is a function of the entering water temperature to the VRF units (TGS).

The power draw ( $\mathrm{KW}_{\text {pump }}$ ) of the ground (or source) loop pump (P-16A/P-16B as shown in Figure 5) is not directly measured. Instead, it is calculated based on the measured flow rate and the pump speed using following correlation:

$$
\mathrm{KW}_{\text {pump }}=\mathrm{KW}_{\mathrm{o}} \mathrm{x}\left(\mathrm{PER} \_\mathrm{P} 16 / 100\right)^{2.5} \text {, }
$$

where PER_P16 is the percentage of the pump speed to its full speed and $\mathrm{KW}_{\mathrm{o}}$ is the power draw of the pump at full speed. For the $60 \mathrm{HP}$ pump, $\mathrm{KW}_{\mathrm{o}}$ would be about $44 \mathrm{~kW}$ (assuming $95 \%$ loaded and with $96 \%$ efficiency). The exponent 2.5 is generally used for pressure-controlled pumps (instead of the exponent 3 dictated by the pump affinity laws).

One limitation of the proposed method for calculating the cooling and heating provided by the VRF units is that it ignores simultaneous heating and cooling, which can occur in multi-zone complex buildings, such as the HBB, especially during shoulder seasons. However, with the limited available data, it is not possible to separate the heating and cooling outputs of the VRF units when they run in heating and cooling modes simultaneously to satisfy various demands in different zones of the building.

To overcome this limitation, a multi-zone hourly simulation model for the building is developed using eQUEST/DOE-2. Then the simulated cooling and heating loads during heating-only and cooling-only seasons (e.g., July, August, December, and January) will be calibrated with the calculated heating and cooling outputs. Once the model is calibrated in this way, the simultaneous heating and cooling loads during shoulder seasons can also be compared with the aggregated cooling and heating loads resulting from the calculation method described above. Finally, simulations with the calibrated model for a conventional HVAC system (e.g., variable air volume with chiller and boiler) are performed to establish a baseline for evaluating the energy and cost savings potential of the demonstrated GS-VRF system. 


\section{ANALYSIS RESULTS}

This section presents the data summary and analysis. The data analyzed in this study were collected by Oakland University from August 2013 through July 2014, which covers a full year. The data analysis includes (1) the operational efficiency of the GS-VRF system, (2) pump control and pumping energy use, (3) ground loop temperatures, and (4) areas having the potential to further improve system efficiency and reduce energy consumption.

\subsection{VRF System Energy Consumption Analysis}

\subsubsection{VRF HP Units Hourly Energy Consumption}

The power consumptions of the water-cooled VRF units were measured at 15-minute intervals. There are ten mechanical closets (two for each floor), and each closet includes four to six units (24 to 42 tons) of Daikin's water-cooled VRF units. Appendix A presents scattered plots of the hourly power consumption of the VRF units in each closet as a function of the outdoor air temperature. These scattered plots show patterns typical for all electric heating and cooling systems, except in three areas of the building. The typical power consumption pattern has a change point at around 50 to $60^{\circ} \mathrm{F}$, and the power consumption increases as the outdoor air temperature increases/decreases from the change point. Three areas - the east and west wings of the first floor and the east wing of the second floor-have nearly constant power consumption throughout the year, which does not show any significant dependence on outdoor air temperatures. Given the large spaces like auditorium/classrooms in these three wings, it could be that there is constant cooling demand throughout the year because of the high internal loads from occupants, lighting, and equipment.

Figure 9 shows hourly data for the aggregated power consumption for all the 50 VRF units. Figure 10 shows the relationship of the aggregated power consumption with the coincidental outdoor temperature. As can be seen in Figure 10, there is a change point at around $55^{\circ} \mathrm{F}$, and the power consumption increases as the temperature increases/decreases from the change point. The peak power draw was around $150 \mathrm{~kW}$ and occurred in early September and the coldest days in January. The minimum power draw (about 25 $\mathrm{kW}$ ) occurred during May through July when the ambient temperature was mild (around $60^{\circ} \mathrm{F}$ ) and the building was unoccupied. A typical GSHP or air-source heat pump system would show close to zero HVAC energy use during unoccupied periods in shoulder season, as the system has a dead band between the heating and cooling set point temperatures (e.g., $70^{\circ} \mathrm{F}$ for heating and $75^{\circ} \mathrm{F}$ for cooling). The installed VRF system can provide simultaneous heating and cooling and the FCUs of the VRF system are controlled to maintain the indoor temperature of each zone they served precisely at a user-specified set point. Therefore, even during shoulder season, the VRF system continuously ran in either heating or cooling mode to maintain the indoor temperature in all of the zones at their individually specified set points.

Figure 11 shows an example of simultaneous heating and cooling during a shoulder season. This figure is a screen snapshot of the building management system (BMS) at 8:20 a.m. on March 10, 2014. The blue colored number under the name of each zone-1 or 2-indicates the FCU in that zone running in cooling or heating mode, respectively. The green colored number under the name of each zone is the zone temperature set point, and the number above the green number is the current zone temperatures. The snapshot shows that there are many instances of simultaneous heating and cooling. In addition, the zone temperature set points in different zones varied from 69 to $76^{\circ} \mathrm{F}$. FCUs in adjacent zones with different temperature set points may run in cooling and heating modes simultaneously, which could result in a waste of energy, especially if these zones are not thermally separated, due to conflicting cooling and heating loads. For example, as shown in Figure 11, FC 1050-2 and FC 1050-3 (shaded in a blue box) are 
the FCUs serving different areas of a large open space; but one of two FCUs ran in cooling mode and the other in heating mode, which caused the conflicting simultaneous heating and cooling described above. Similar power consumption patterns and the conflicting simultaneous heating and cooling in adjacent zones were also observed in the ASHRAE Headquarters building, which uses a similar but an air-source VRF system (Southard et al. 2014).

Several other issues are also identified in Figure 11. First, it appears the FCUs in many zones did not maintain the zone temperatures at their set points. For example, the FCU in zone FC5015 ran in cooling mode with a set point of $73^{\circ} \mathrm{F}$; but the zone temperature was $68.6^{\circ} \mathrm{F}$ (shaded in an orange box in the figure), which indicates overcooling in this zone. It is also likely that there is a problem in the VRF control system that prevents the FCU from running in heating mode in that situation. Similar patterns can also be found in FC1006-1, FC 3065, FC 5020, and others. On the other hand, it was also found that some zones (e.g., FC3011) were overheated. Appendix B provides additional snapshots of the BMS screen for six different times of the year. Additional snapshots of the BMS reveal that, although the VRF system mostly provides cooling during summer seasons (see the snapshot for August 2014), there are significant numbers of FCUs running in cooling mode during winter season (see the snapshot for December 2014).

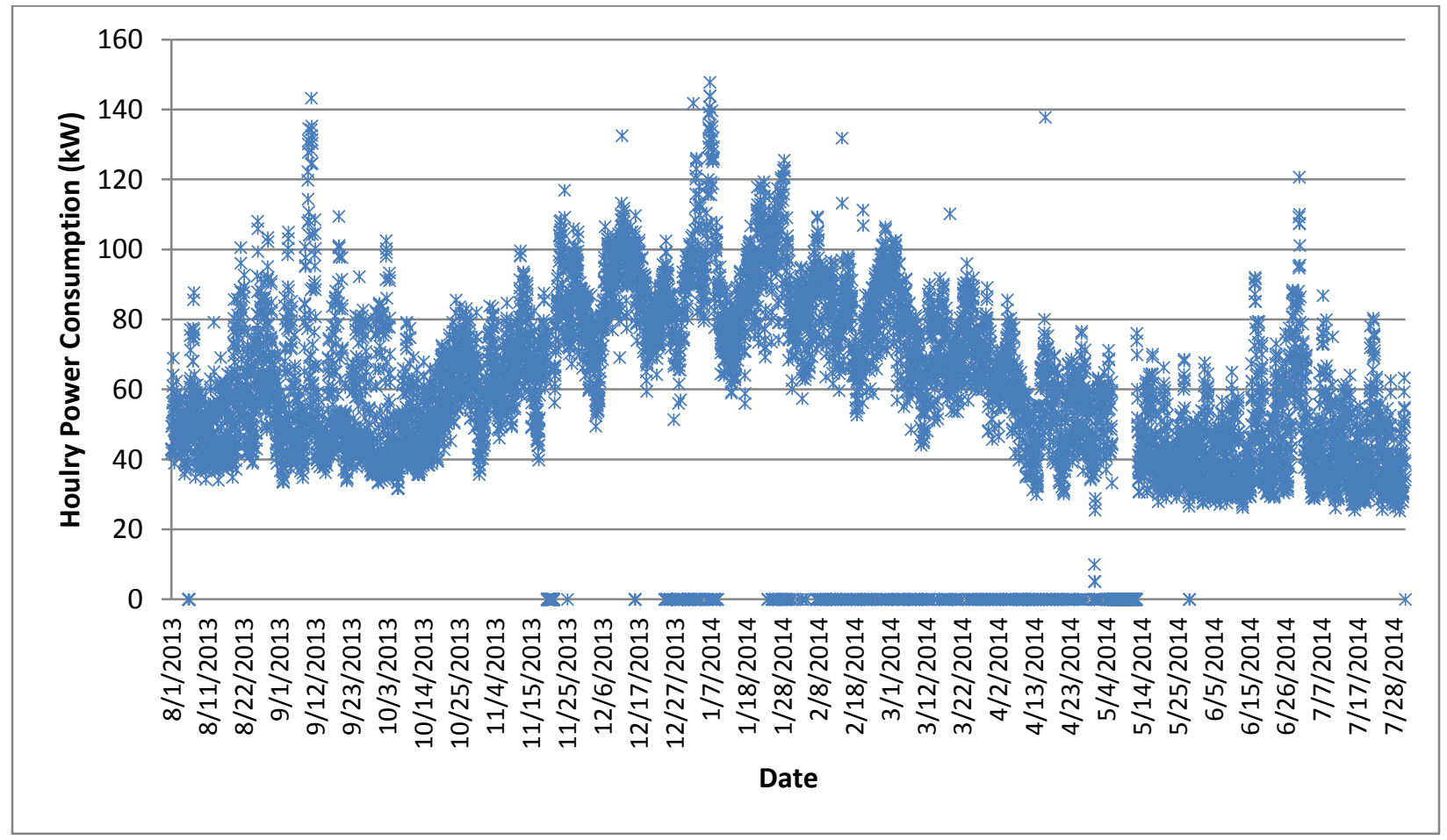

Figure 9. Aggregated power draw from all of the $50 \mathrm{VRF}$ units in the building. 


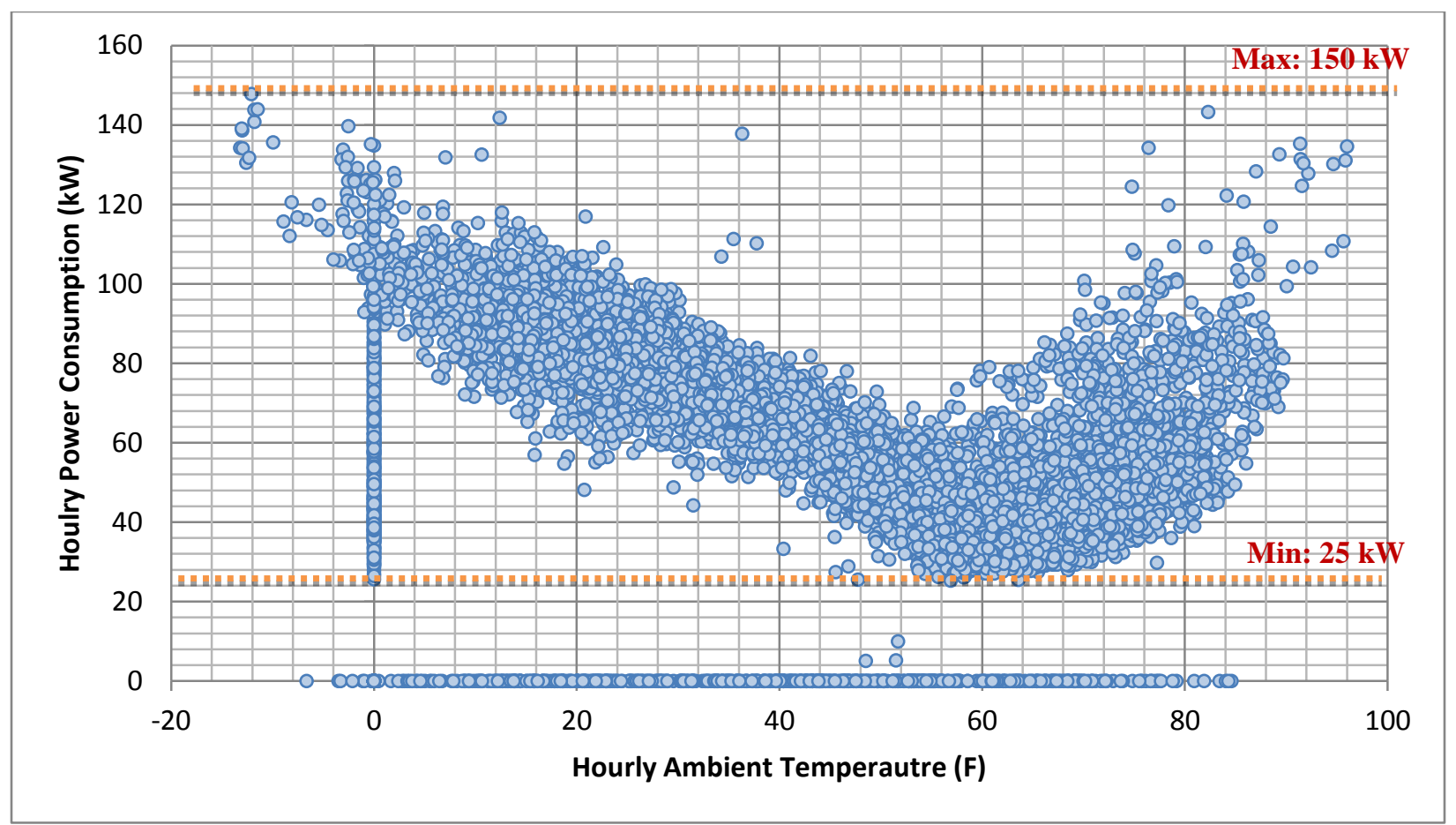

Figure 10. Trend of aggregated power draw of the $50 \mathrm{VRF}$ units versus outdoor air temperature.

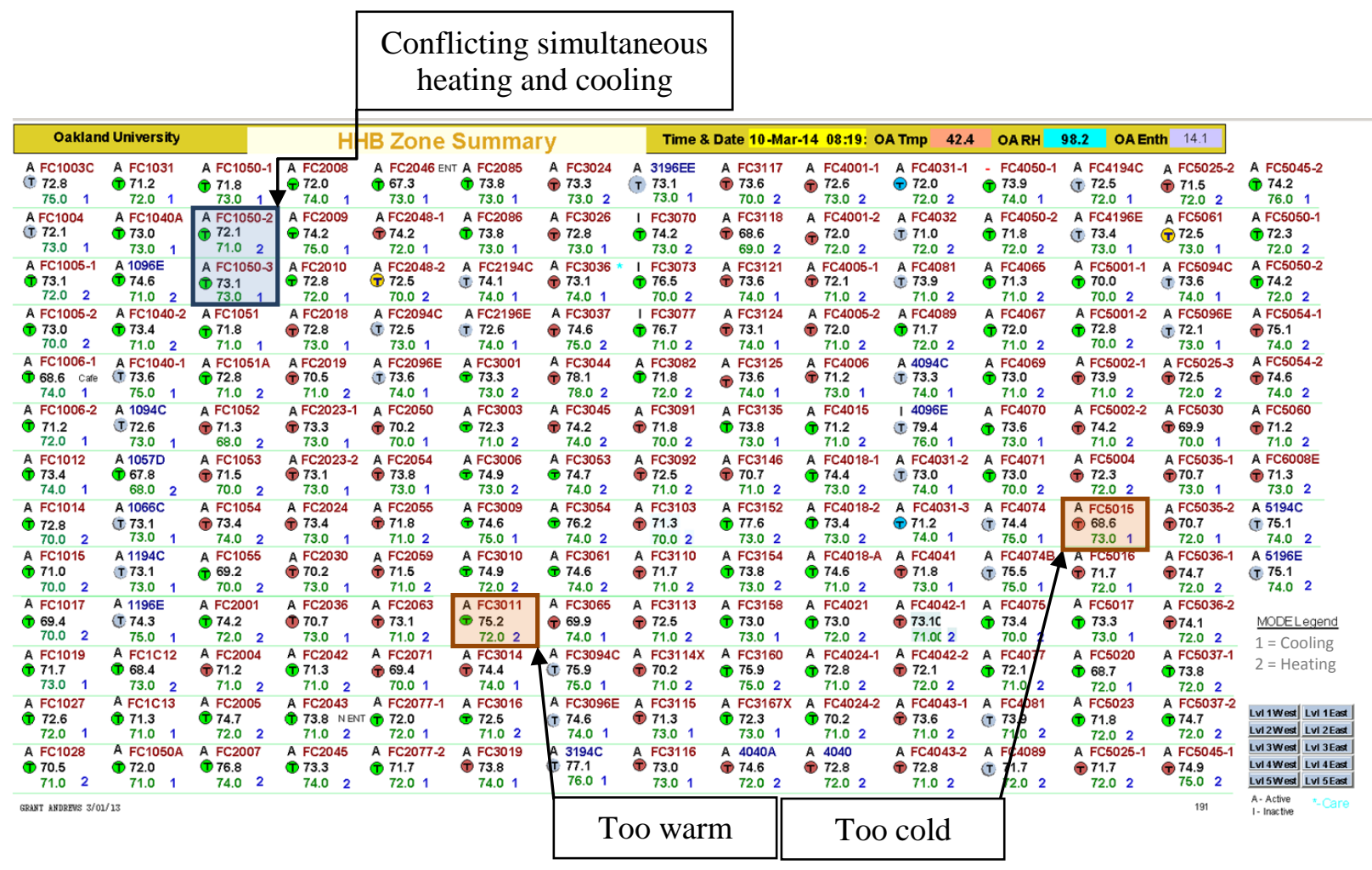

Figure 11. Building management system snapshot of all zone temperatures at 08:19 a.m. on March 10, 2014. 


\subsubsection{VRF HP Unit Daily Energy Consumption}

Since there are many missing data points for the measured hourly power consumption of the VRF system during the monitoring period, it is necessary to fill in the missing data to estimate the daily, monthly, and annual power consumption of the VRF system. Therefore, an inverse modeling technique was adopted to develop a model for predicting the daily power consumption of the VRF system as a function of the coincidental daily outdoor air temperature. The ASHRAE Inverse Modeling Toolkit (IMT) was used to develop the model. The IMT outputs show a fairly good fit $\left(\mathrm{R}^{2}=0.827\right)$ between the model predictions and the measured power consumption data. This is a 4-parameter model as shown in Eqs. (7) and (8).

If $\mathrm{OA}_{\text {temp }}>64.75^{\circ} \mathrm{F}$ :

Daily VRF power consumption $(\mathrm{kWh})=52.93 \times\left(\mathrm{OA}_{\text {temp }}-66.75\right)+957.86$

If $\mathrm{OA}_{\text {temp }}<64.75^{\circ} \mathrm{F}$ :

$$
\text { Daily VRF power consumption }(\mathrm{kWh})=-26.10 \times\left(\mathrm{OA}_{\mathrm{temp}}-66.75\right)+957.86
$$

This model was used to predict the daily power consumption for days with missing data (there are 126 days with all or part of the hourly data missing).

Figure 12 shows a scatter plot of the daily power consumption with and without the missing data filled in. With the missing data filled with the model predictions, the total annual VRF power consumption from August 2013 through July 2014 was estimated at 564,664 kWh, which is $41 \%$ more than that calculated with only the available measured data.

\subsubsection{Loop Pumping Control Analysis}

The system is controlled through the BMS and operates continuously (day and night, weekday and weekend) during the entire year. The lead pump (pump P16A, shown in Figure 5) and the lag pump (pump P16B) are switched on a monthly basis. According to the control sequence provided by the facility manager, the pump speed is controlled to maintain the pressure differential between the supply and return mains of the heat pump loop at a given set point (shown as "DP" in Figure 5).

There are no direct measurements for the pumping power. Instead, the speeds of the two pumps (indicated by the percentage of its full speed) have been monitored. Figure 13 presents the time series of the speeds of the two pumps. As shown in Figure 13, there is a distinct difference in the pump speed between heating (extracting heat from the ground) and cooling seasons (rejecting heat to the ground). During the cooling season, it appears the pump speed varied within 60 to $80 \%$ of its full speed, but it was higher during the heating season-between 80 and $100 \%$ of its full speed.

Figure 13 also shows that the temperature differential between the supply and return of the ground loop had different patterns in the cooling and heating seasons - it fluctuated between 0 and $20^{\circ} \mathrm{F}$ in cooling season but stayed at less than $1^{\circ} \mathrm{F}$ in heating season. This pattern was found to be resulting from the following system operation and control issues:

- All the two-way valves of the VRF units are open to allow water to flow through the VRF units even when they are not called on to run. 
- There is a 3-way valve between the main loop (serving the VRF units and the geo-chiller) and the ground loop. The 3-way valve is controlled to bypass the ground loop if the return water from the main loop is below $80^{\circ} \mathrm{F}$ and higher than $55^{\circ} \mathrm{F}$.
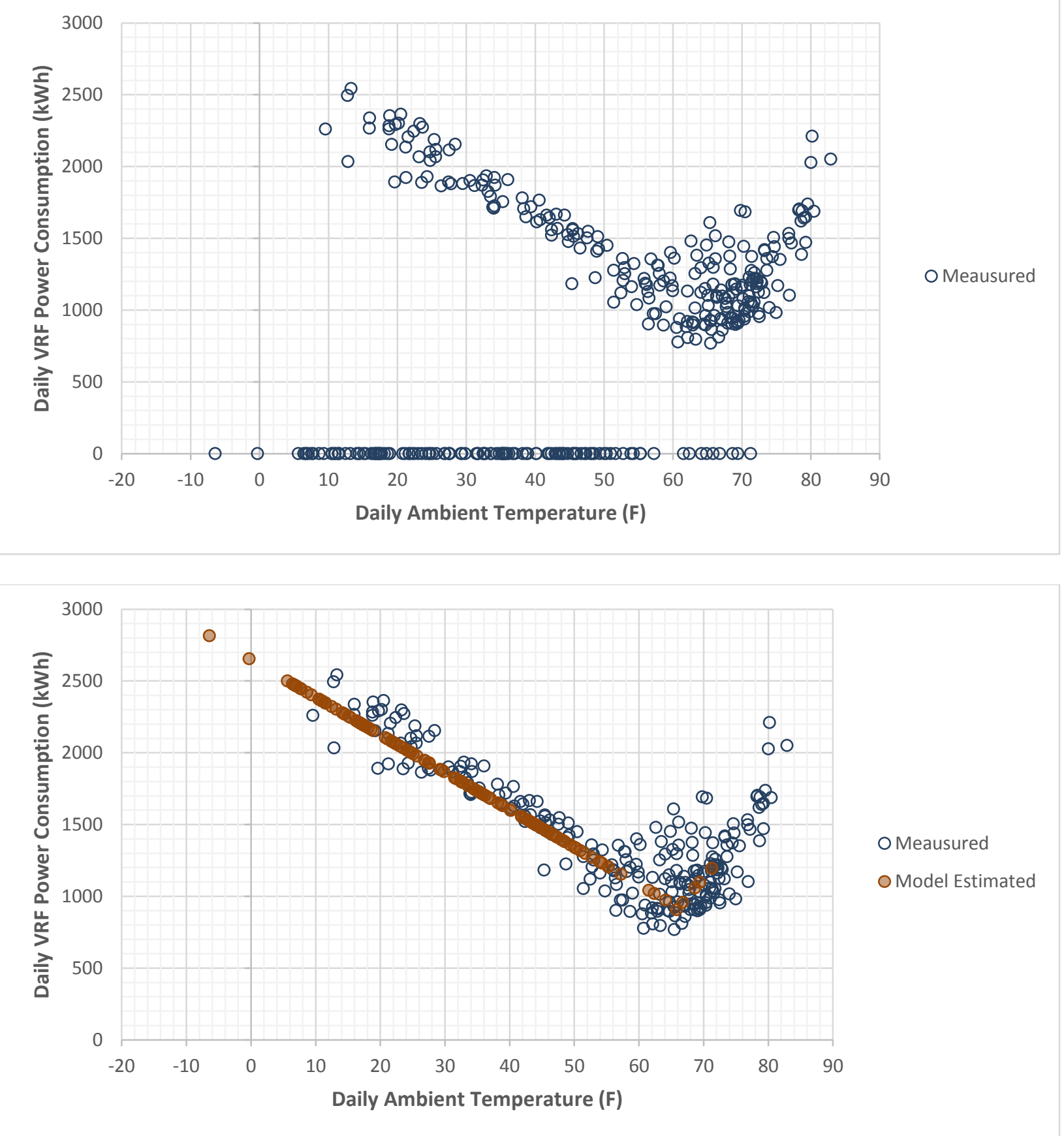

Figure 12. Daily combined VRF unit power consumption with missing data (upper) and with missing data filled in (lower). 


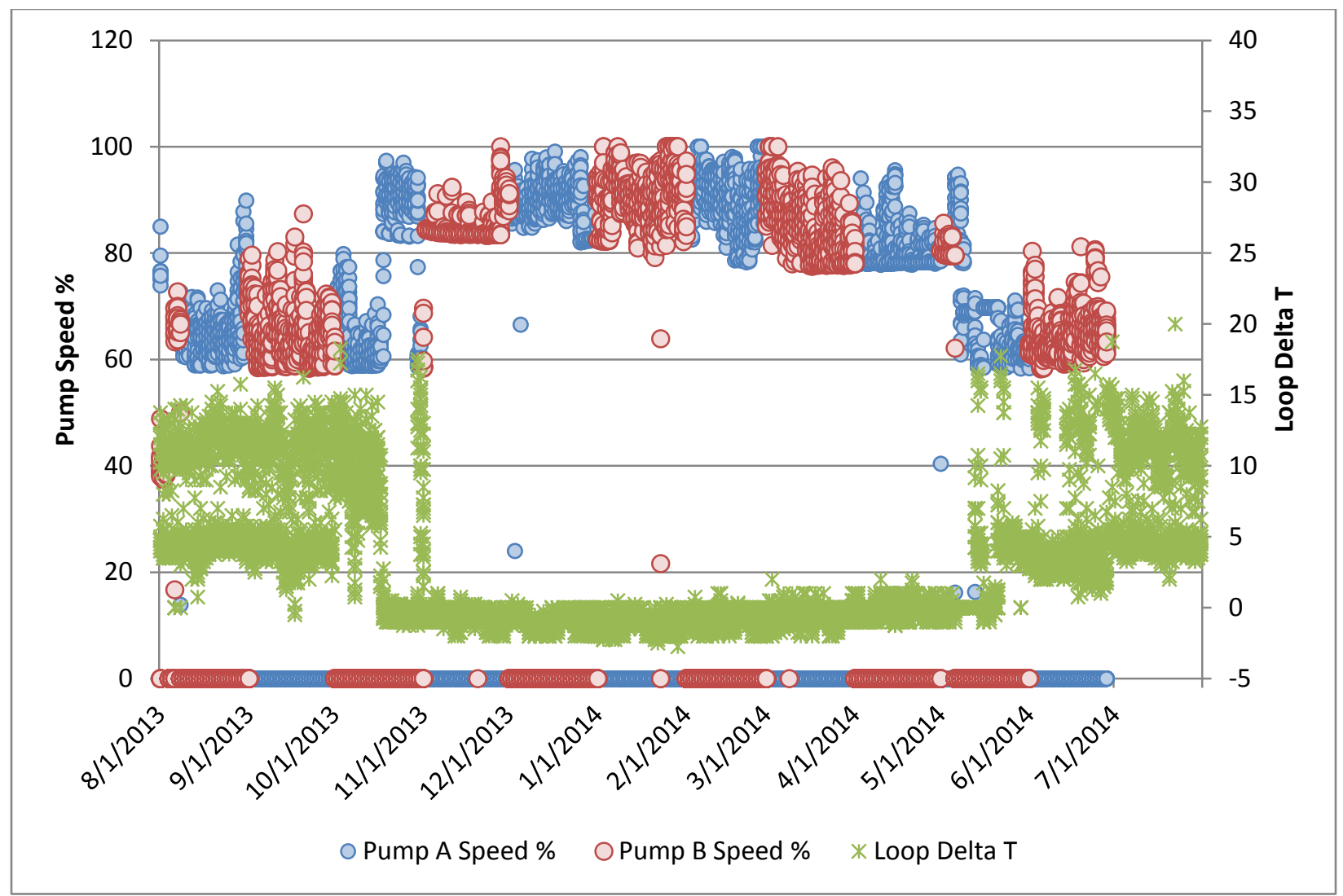

Figure 13. Pump speed (percentage of its full speed) and the coincidental temperature differential at the ground loop.

During heating season, since the VRF and geo-chiller extracted heat from the ground, which is only $51{ }^{\circ} \mathrm{F}$ even without any heat extraction, the return water temperature from the main loop was always below $55^{\circ} \mathrm{F}$. As a result, the 3 -way valve remained open to route all the water flow in the main loop to the ground loop, and the pumps in the main loop ran continuously at nearly full speed (the fluctuation of the pump speed in heating season was due to the intermittent operation of the geo-chiller). Because of the large, nearly constant water flow through the ground loop, the temperature differential in the ground loop was very low (less than $1^{\circ} \mathrm{F}$ ). It indicates excessive pumping in the system.

On the other hand, the ground loop was bypassed frequently in cooling season because the return water temperature in the main loop was below $80^{\circ} \mathrm{F}$ most of the time, given the low ground temperature $\left(51^{\circ} \mathrm{F}\right)$, moderate cooling loads in the building, and large water flow through the VRF units. When the ground loop was bypassed, its associated head loss was also bypassed, so that the pump ran at a slower speed to maintain the pressure differential set point at the main loop. Although the bypass did reduce pumping power, it sacrificed some of the cooling efficiency of the heat pump as a result of the elevated water temperature in the main loop when the ground loop was bypassed. As shown in Figure 13, even with the ground loop bypassed, the pumps never ran below 50\% of their full speed because of the always-open two-way valves and the resulting constant water flow through the VRF units.

It is strongly recommended that Oakland University staff work with the VRF manufacturer to evaluate the operation of the two-way valves. If the two-way valves are turned on and off, or even better modulating valves are used instead and they are modulated, with the operation of the VRF units, the pump speed and 
the associated pumping power can be significantly reduced during most of the year when the building heating and cooling loads are not at peaks.

\subsubsection{VRF System Energy Consumption Analysis}

The hourly pumping power consumption was calculated using Eq. (6) and the measured speed of the pumps. The power consumption of the indoor FCUs of the VRF system (due mainly to the fans) was not measured but was estimated based on manufacturer's catalog data. It was also assumed that the FCU fans ran continuously at full speed because it was observed that the FCUs ran in either heating or cooling mode most of the time. Daily power consumption of the VRF units, pumps, and FCUs were aggregated to estimate the monthly power consumption of the entire GS-VRF system (Figure 14).

According to the mechanical drawings and the equipment schedules, there are 189 FCUs of 7 different sizes. The input power $(\mathrm{kW})$ and the air flow (CFM) for each FCU size were obtained from the manufacturer's specification sheets and were used to calculate the total power draw and average fan efficiency of all the FCUs, which is expressed as the ratio of the total power draw to the total air flow rate of all the FCUs. The average fan efficiency was used as an input value in the simulation described later in this report to estimate the annual power consumption of the FCU fans. The calculated total power draw of all the FCUs is around $42 \mathrm{~kW}$ and the total air flow is 131,572 CFM (i.e., 0.3 W/CFM).

The annual power consumption analysis shows that the pumps and the FCUs account for 16 and $33 \%$ of the power consumption of the entire GS-VRF system, respectively. As shown in Figure 15, the monthly pumping energy fractions over the 12 months vary from 10 to 20\%, with the lowest in August (when the system was in cooling mode operation and had highest cooling loads) and the highest in April (when the system was in heating operation but had the smallest heating loads).

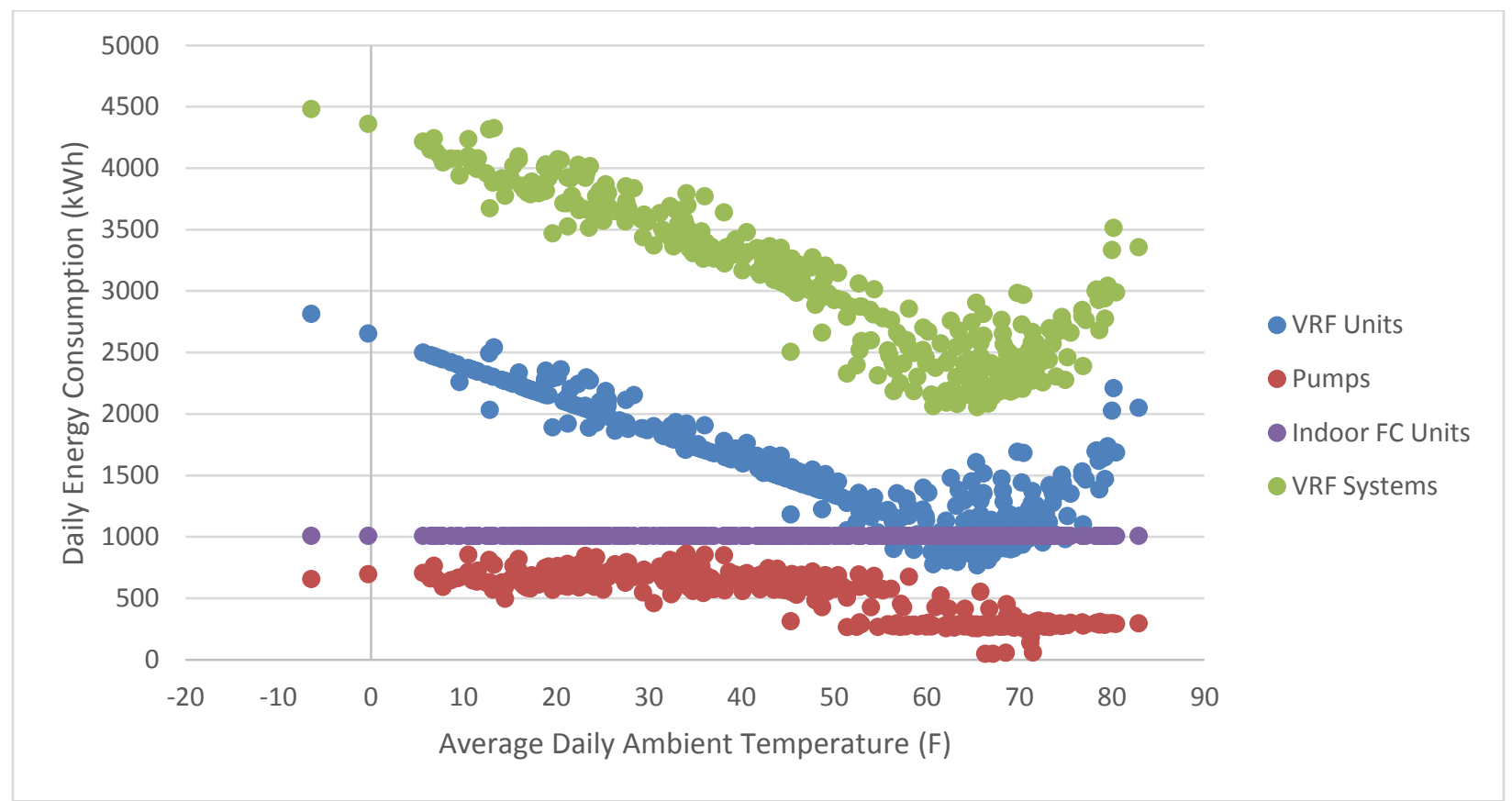

Figure 14. Daily power consumption of GS-VRF system and each end use. 


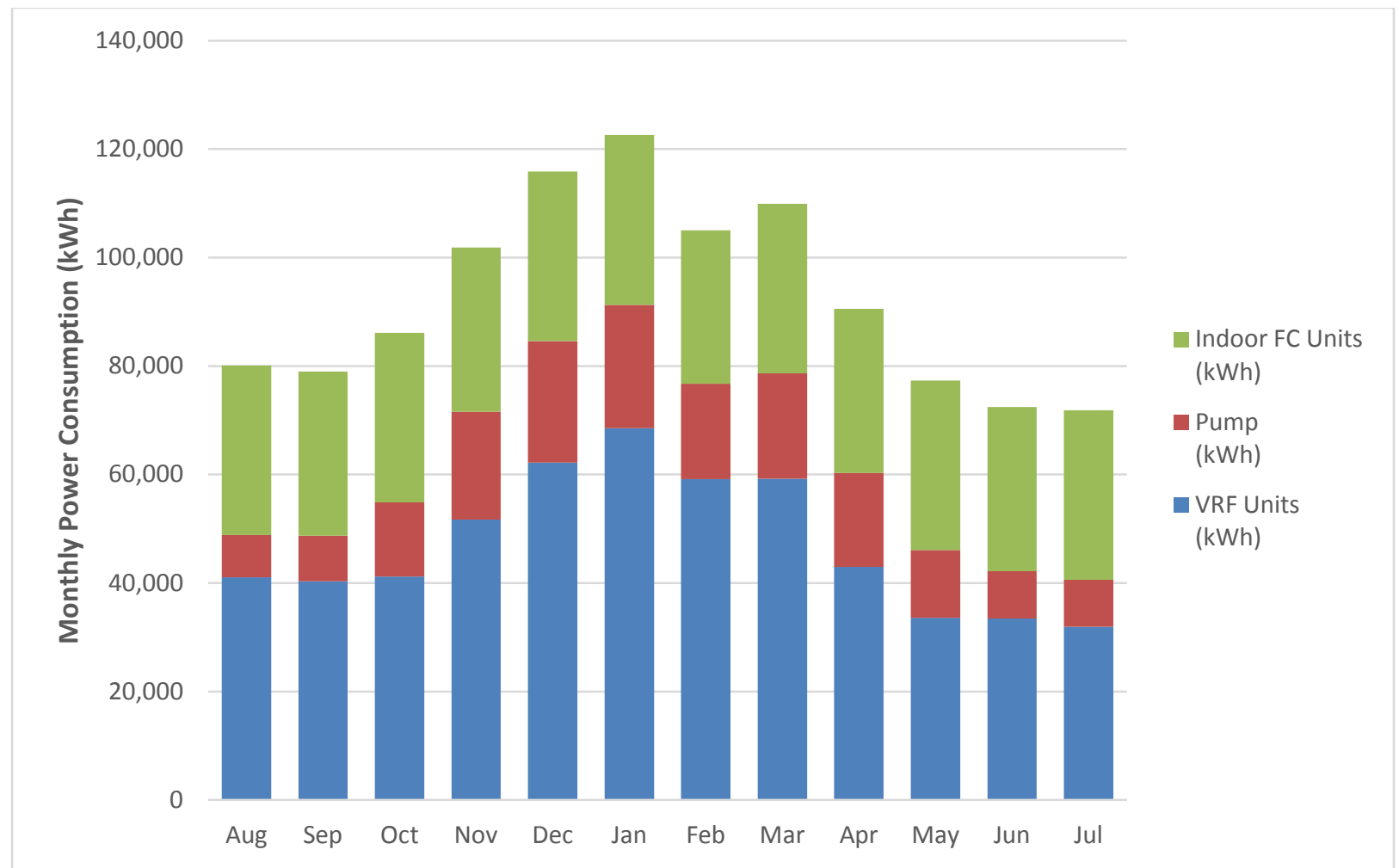

Figure 15. Monthly power consumption of VRF units, indoor FCUs, and pumps.

\subsection{Ground Loop Temperatures and Heat Transfer}

Figure 16 shows a time series plot for the ground loop supply and return temperatures, as well as the temperature differential between the supply and return lines of the ground loop. The measured ground loop supply temperatures (red diamond in the figure) were around $60^{\circ} \mathrm{F}$ from August 2013 until they dropped below $60^{\circ} \mathrm{F}$ in October 2014 when the ground loop started extracting heat from the ground. Starting in June 2014 , the ground loop supply temperatures returned to and stayed within the $60-70^{\circ} \mathrm{F}$ range. As shown in Figure 16, the ground loop supply temperature was higher than the coincidental ambient temperature during most of the time in the heating season (from November 2013 through April 2014). The average ground loop temperature differential during heat rejection (when the return temperature is higher than the supply temperature) was about $10^{\circ} \mathrm{F}$, but it was less than $1^{\circ} \mathrm{F}$ during heat extraction (when the return temperature is lower than the supply temperature). The very small temperature differential during heat extraction indicates excessive pumping.

Figure 17 shows the ground heat transfer (Q - heat rejection and extraction) to and from the ground. It appears that 55 to $60^{\circ} \mathrm{F}$ is the change point for heating/cooling mode, as is also shown in Figure 10 . Mixed cooling and heating operation can be observed when the outdoor air temperature is between 35 and $60^{\circ} \mathrm{F}$. It indicates there may be simultaneous heating and cooling occurring in various zones of the building. The annual cumulative heat rejection and extraction were calculated at 1,792 MMBtu and 1,662 MMBtu, respectively. It indicates that about $8 \%$ more heat was rejected to the ground than was extracted on an annual basis. Given such a small heat imbalance, the 60 to $70^{\circ} \mathrm{F}$ ground loop supply temperature in the first two years of operation indicates that the ground heat exchanger may be oversized since it is usually sized to maintain the supply temperature not higher than $95^{\circ} \mathrm{F}$ for 20 years of operation. 


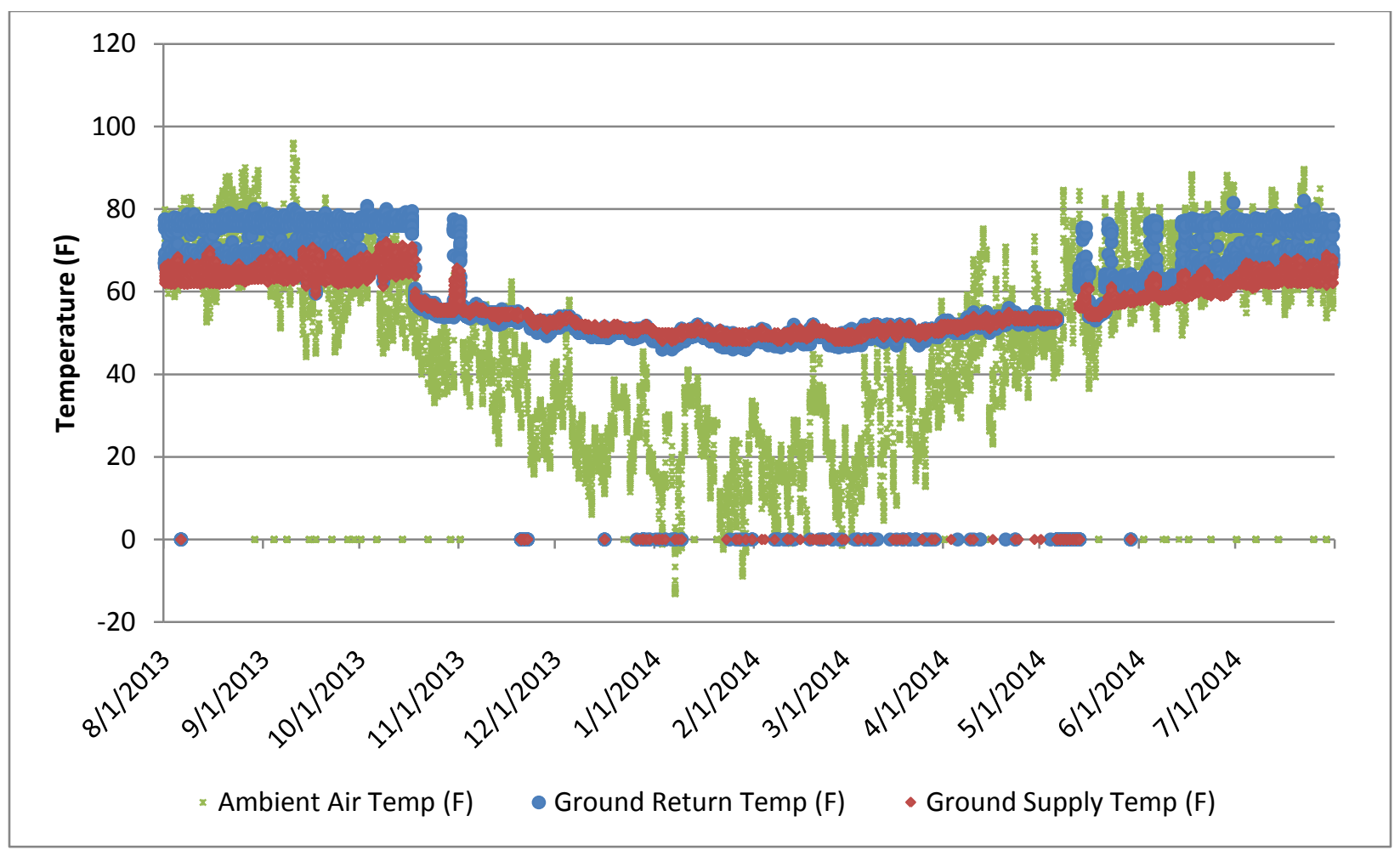

Figure 16. Ground loop temperatures and the coincidental ambient temperatures. 


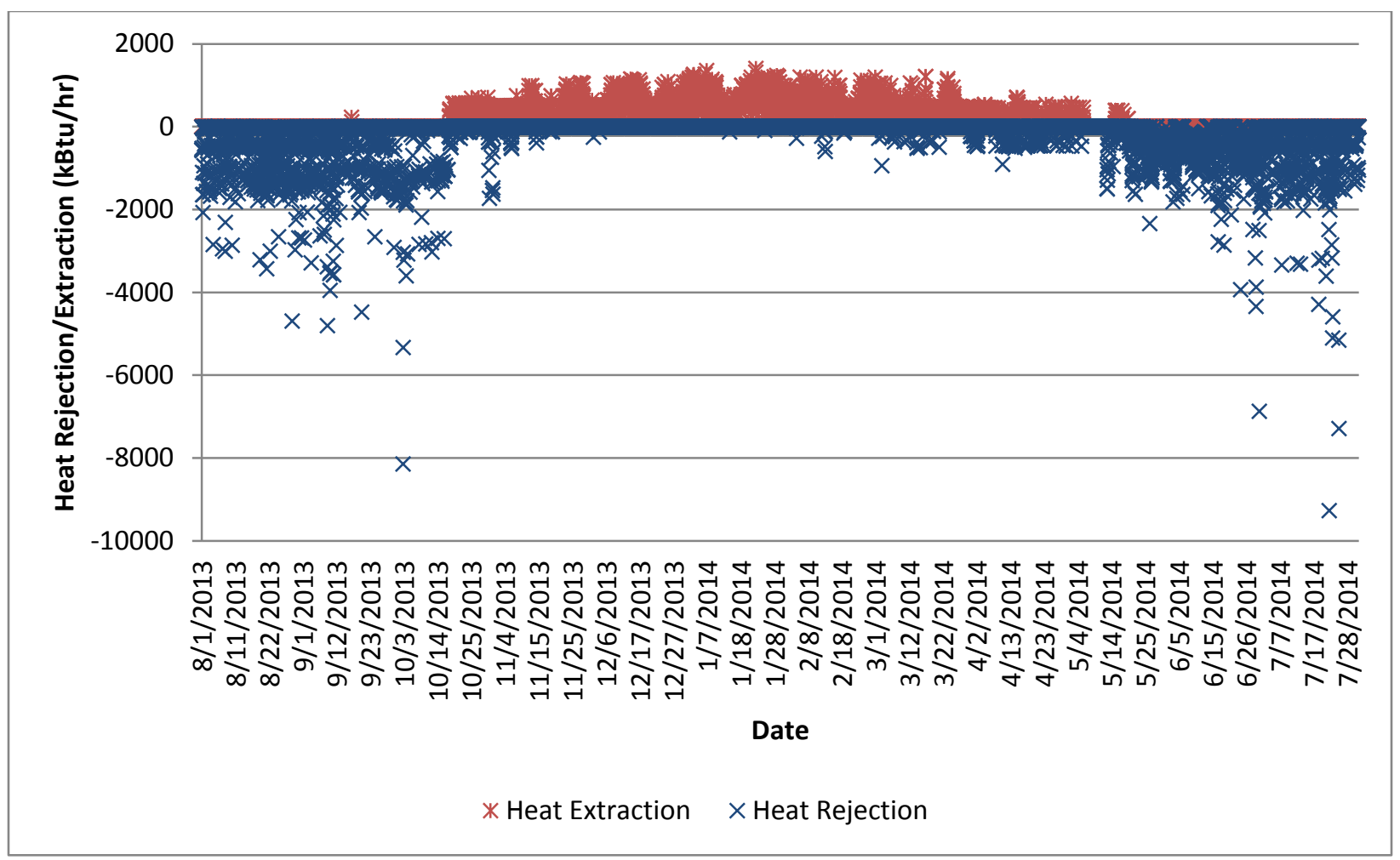

(a)

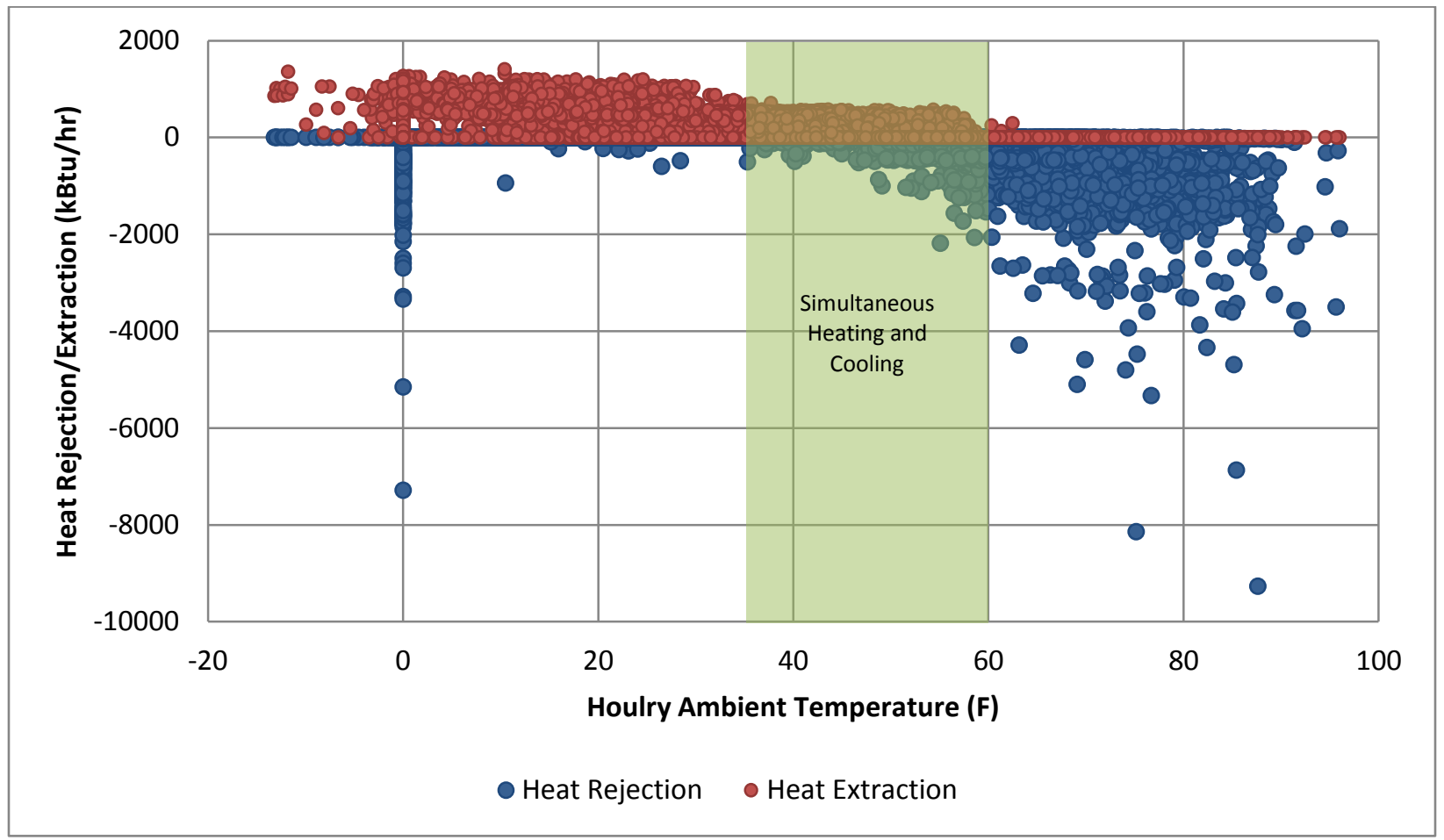

(b)

Figure 17. Ground loop heat transfer: (a) time series plot and (b) scatter plot compared with the outdoor air temperature. 


\subsection{Heating and Cooling Loads and System Performance}

Performance curves of the Daikin water-source VRF units were obtained from the manufacturer's website. Based on these curves, correlations were derived to estimate the unit efficiencies in heating and cooling modes with the entering water temperatures (supply temperatures of the main water loop). Then the hourly cooling and heating loads were calculated using Eqs. (4) and (5). Given the limited available data, the simultaneous heating and cooling provided by the VRF units cannot be calculated separately. It is thus assumed that all the output of the VRF units is for cooling when the ambient temperature is higher than $55^{\circ} \mathrm{F}$ and it is only for heating when the ambient temperature is lower than $55^{\circ} \mathrm{F}$. This assumption may underestimate the actual heating and cooling provided by the VRF units when both heating and cooling are simultaneously provided. The estimated hourly cooling and heating loads are shown in Figure 18. It appears the peak cooling and heating capacities are $2,440 \mathrm{kBtu} / \mathrm{h}(203 \mathrm{ton})$ and $1,800 \mathrm{kBtu} / \mathrm{h}(150$ ton), respectively. Given that the total size of the installed VRF units is 320 ton, it appears the VRF units are oversized.

The monthly heating and cooling COPs of the GS-VRF system were calculated with the heating/cooling outputs estimated above, the measured power consumption of the VRF units (missing data filled in with the predictions of the inverse modeling), the calculated pumping power consumption (based on the measured pump speed), and the calculated indoor FCU power consumption, as expressed in Eqs. (9) and (10).

$$
\begin{aligned}
\text { System Cooling COP } & =\frac{V R F \text { Delivered Cooling }- \text { Fan Power }(\text { Cooling })}{V R F \text { Power }(\text { Cooling })+\text { Fan Power }(\text { Cooling })+\text { Pump Power }(\text { Cooling })} \\
\text { System Heating COP } & =\frac{V R F \text { Delivered Heating }+ \text { Fan Power }(\text { Heating })}{V R F \text { Power }(\text { Heating })+\text { Fan Power }(\text { Heating })+\text { Pump Power }(\text { Heating })}
\end{aligned}
$$

Figure 19 and Figure 20 show the monthly cooling and heating COPs, respectively. The average cooling and heating COPs for the GS-VRF system were 2.3 and 2.2, respectively. It should be noted that, since the simultaneous heating and cooling provided by the GS-VRF system was not accounted for due to the limited available data, these calculated COPs are conservative.

Excluding the power consumption of the circulation pumps and the indoor FCUs, the average COPs for the VRF units in cooling and heating mode were 5.8 and 3.6, respectively. The manufacturer's catalog data show that the cooling and heating COPs of the installed VRF units under rating conditions ${ }^{1}$ are 4.0 and 4.7, respectively. The average measured cooling COP is higher than the rated cooling COP because the average ground loop supply temperature during cooling operation is lower than the rating condition. On the other hand, the average measured heating COP is lower than the rated value because the average ground supply temperature during heating operation is lower than the rating condition.

\footnotetext{
${ }^{1}$ Cooling rating condition: $80^{\circ} \mathrm{F}$ dry bulb $/ 67^{\circ} \mathrm{F}$ wet bulb indoor air and $85^{\circ} \mathrm{F}$ water source supply temperature. Heating rating condition: $70^{\circ} \mathrm{F}$ dry bulb indoor air and $70^{\circ} \mathrm{F}$ water source supply temperature.
} 


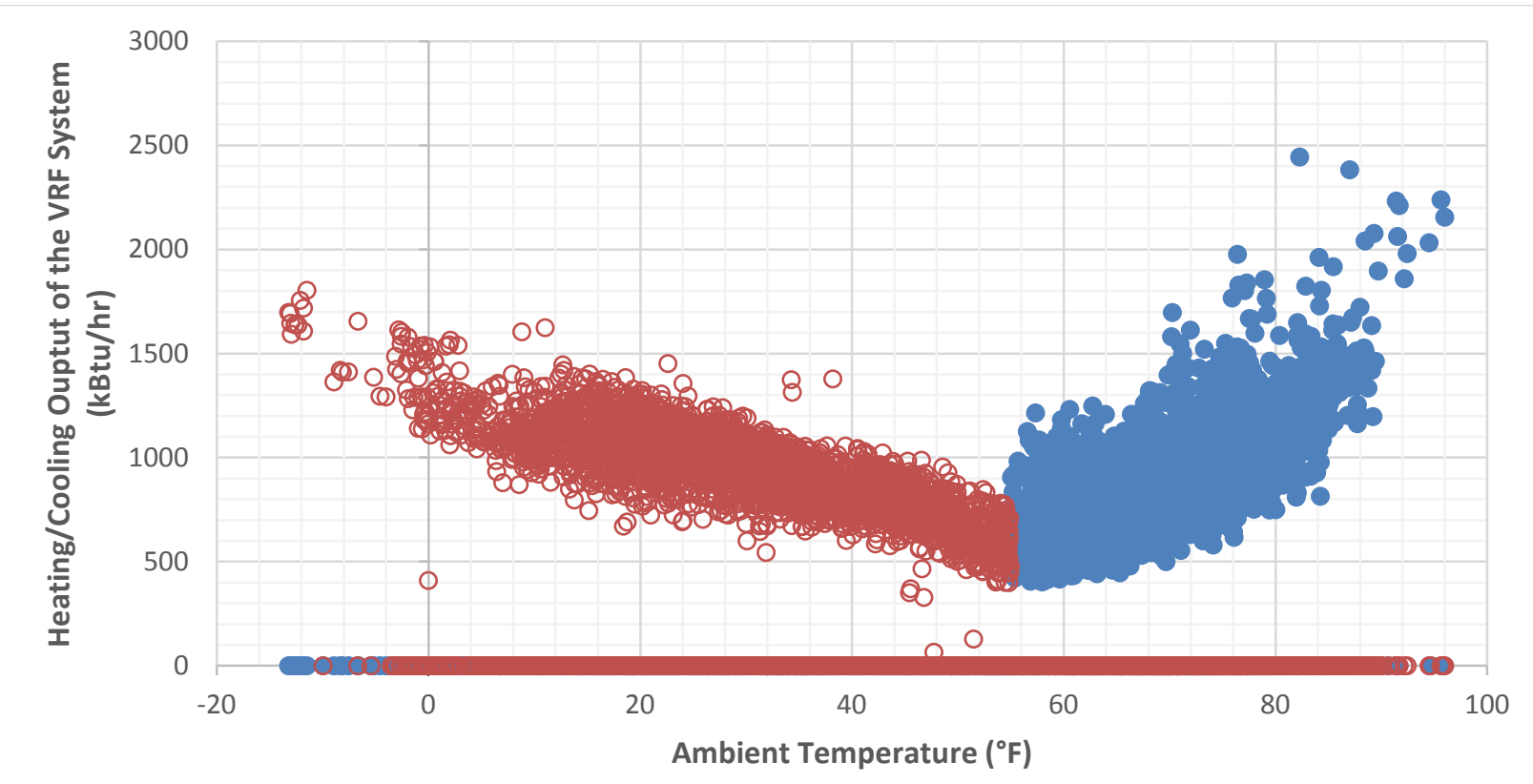

- Cooling Ouputs (OA>55F) O Heating Outputs (OA<55F)

Figure 18. Estimated hourly cooling and heating outputs of the GS-VRF system.

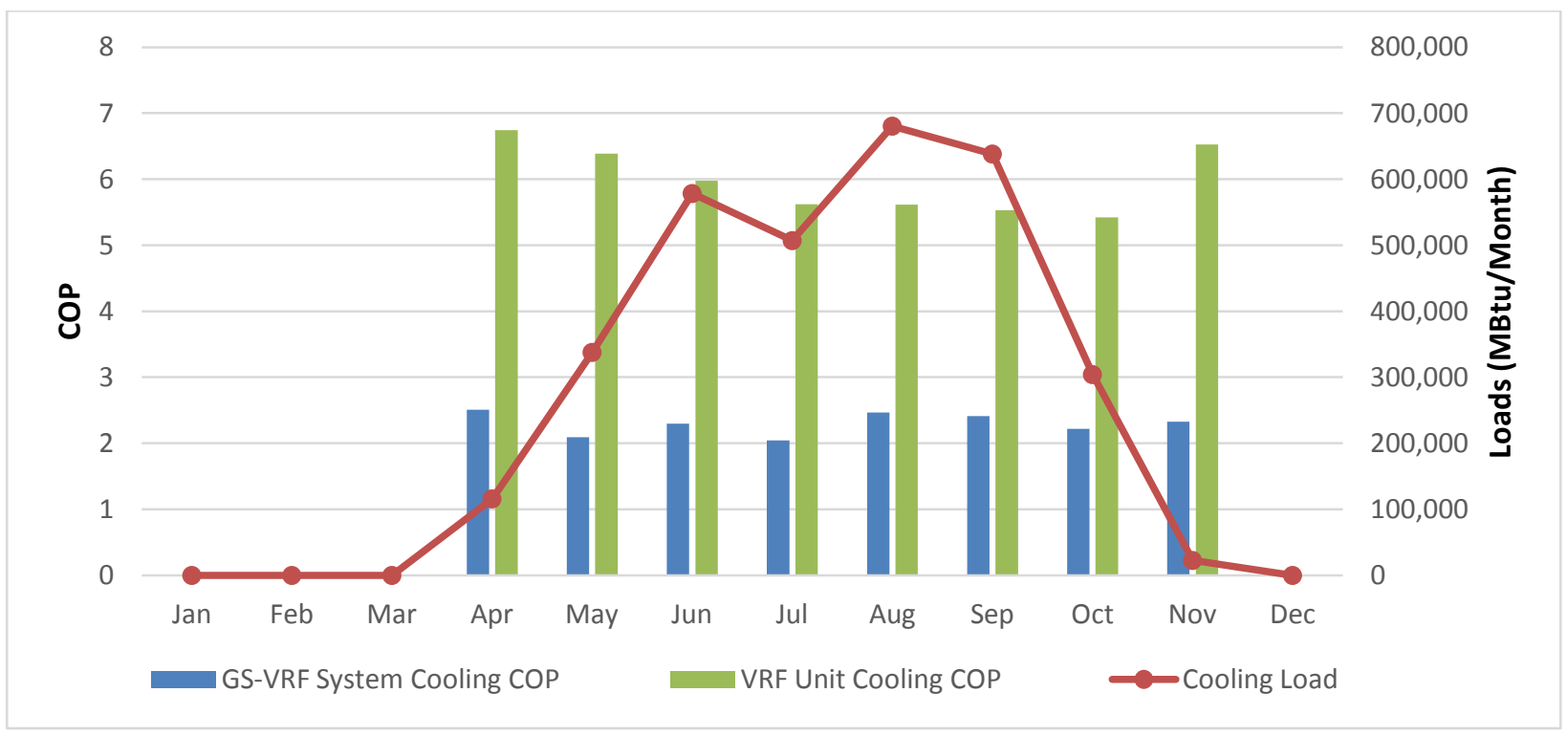

Figure 19. Monthly cooling load and efficiency of VRF units and GS-VRF system. 


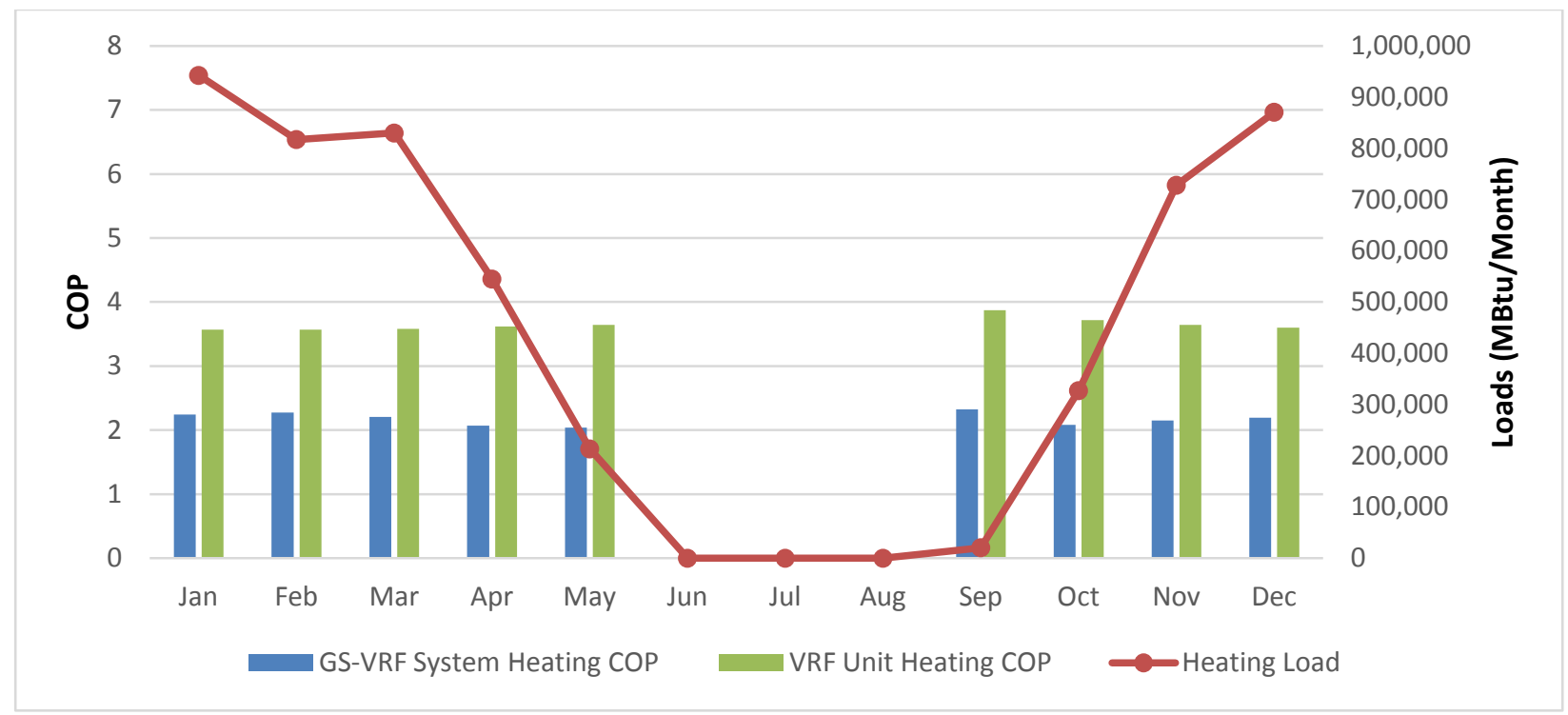

Figure 20. Monthly heating load and efficiency of VRF units and the GS-VRF system. 


\section{ENERGY SAVINGS POTENTIAL}

\subsection{Calibrated Hourly Building Energy Model}

Since the demonstrated GS-VRF system is in a new building, there are no existing baseline energy data to compare with measured data. Therefore, an hourly building energy simulation model for the host building and the GS-VRF system was developed with a building simulation program, eQUEST, version 3.64 (Hirsch et al. 2013). This model was calibrated with the measured data. The calibrated simulation model was then modified to simulate a conventional HVAC system and predict its energy consumption, which was used as a baseline to be compared with the measured power consumptions of the GS-VRF system.

The following assumptions were made in the computer model:

1. The many zones in each floor of the building were aggregated into a few large zones, each one conditioned by one indoor FCU.

2. Only the GS-VRF system was modeled for the building. The DOAS was not included in the model because it supplies conditioned outdoor air at room temperature (i.e., $70^{\circ} \mathrm{F}$ ) and thus does not have a significant impact on the heating and cooling loads of each zone.

3. A model for conventional GSHP systems was modified to approximately simulate the GS-VRF system since the current version of eQUEST cannot model the GS-VRF system. Performance curves of the VRF units obtained from manufacturer's published literature were used to replace those for the conventional GSHP units. The performance curves and the approximation algorithm for the simulation are provided by the VRF manufacturer (Daikin 2014).

4. The monthly average supply water temperature from the ground loop to the VRF unit (as shown in Figure 21) was calculated from the measured data and used in the simulation. The three-way valve operation and the resulting temperature changes in the ground loop were not modeled due to the limited capability of eQUEST.

5. All the zones have an identical room temperature set point of $72^{\circ} \mathrm{F}$ during each hour of the entire year.

6. The original heating and cooling COPs of the VRF units stated in the manufacturer's specifications were used in the model and were slightly modified later, during the calibration process, to match the measured power consumption data.

7. The building operates continuously all year long.

Figure 22 shows a three-dimensional rendering of the developed building model. After the initial model was developed, it was calibrated with the measured power consumption data for the VRF units and the pumps, as well as the calculated cooling and heating outputs of the VRF system. The measured data indicate that the single-point control strategy of the VRF system may have resulted in conflicting simultaneous cooling and heating as a result of the various room temperature set points in different zones of the building, especially during shoulder seasons. However, this conflicting simultaneous heating and cooling cannot be simulated with the current model. Therefore, the focus of the calibration process was to match the peak cooling and heating outputs, rather than to match the annual cumulative heating/cooling outputs of the VRF system.

Figure 23 shows the simulation-predicted and measured cooling and heating outputs against the coincidental ambient air temperature. As shown in Figure 22, the predicted cooling and heating outputs matched the measured data fairly well when the ambient temperatures were above $80^{\circ} \mathrm{F}$ or under $10^{\circ} \mathrm{F}$. This indicates that the model predicts the peak cooling and heating demands fairly well. The measured loads are higher than the predicted loads at other ambient air temperatures. That outcome is expected 
since the simulation does not account for the conflicting simultaneous heating and cooling observed in the real building.

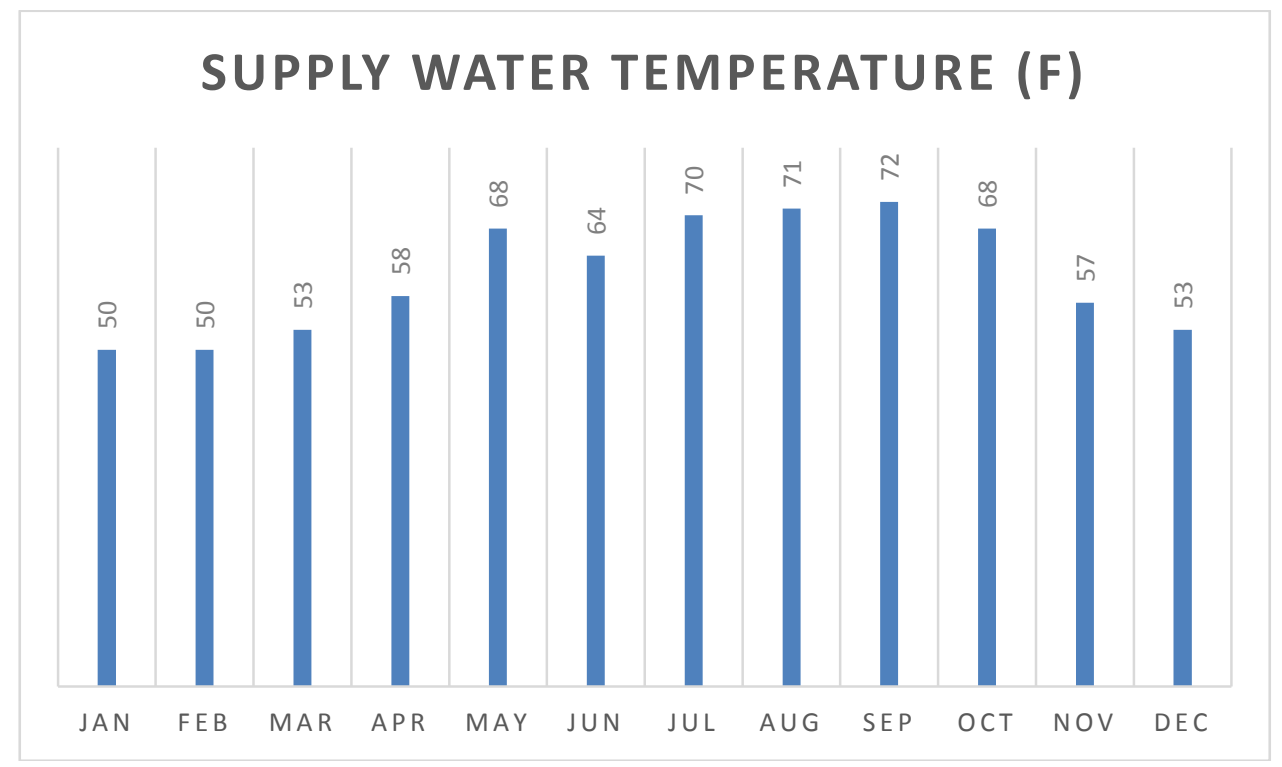

Figure 21. Monthly supply water temperature from the ground loop.

The model was further calibrated by varying the COPs of the VRF units to match the measured power consumption at peak cooling and heating loads. Figure 24 shows the predicted and measured hourly VRF power consumption against ambient air temperatures. Like the comparison between the predicted and measured building loads, the predicted and measured power consumption at the high and low ends of the ambient temperature range match fairly well. However, the predicted VRF power consumption in mild weather (with ambient temperatures ranging from 30 to $70^{\circ} \mathrm{F}$ ) is lower than the measured power consumption; that result is thought to be due to the reasons discussed in the previous paragraph.

The simulation-predicted annual combined cooling and heating output of the VRF units is 5,056 MMBtu, which is $39 \%$ lower than the measured (calculated with Eqs. [4] and [5]), which is 8,344 MMBtu. The simulation-predicted annual power consumption of the VRF units and the circulation pumps is 647 $\mathrm{MWh} /$ year, which is $13 \%$ lower than the measured power consumption ( $744 \mathrm{MWh} /$ year). It is thought that these discrepancies are partially due to that the simulation did not account for the simultaneous heating and cooling of the VRF system. As discussed previously, the control of the GS-VRF system resulted in conflicting simultaneous heating and cooling in adjacent zones, which may have led to the heating and cooling outputs of the GS-VRF system greater than actually needed to maintain the zone temperatures. Rather than predicting the actual performance of the installed GS-VRF system, the simulation estimates the heating and cooling loads for maintaining the zone temperatures at a given set point. 


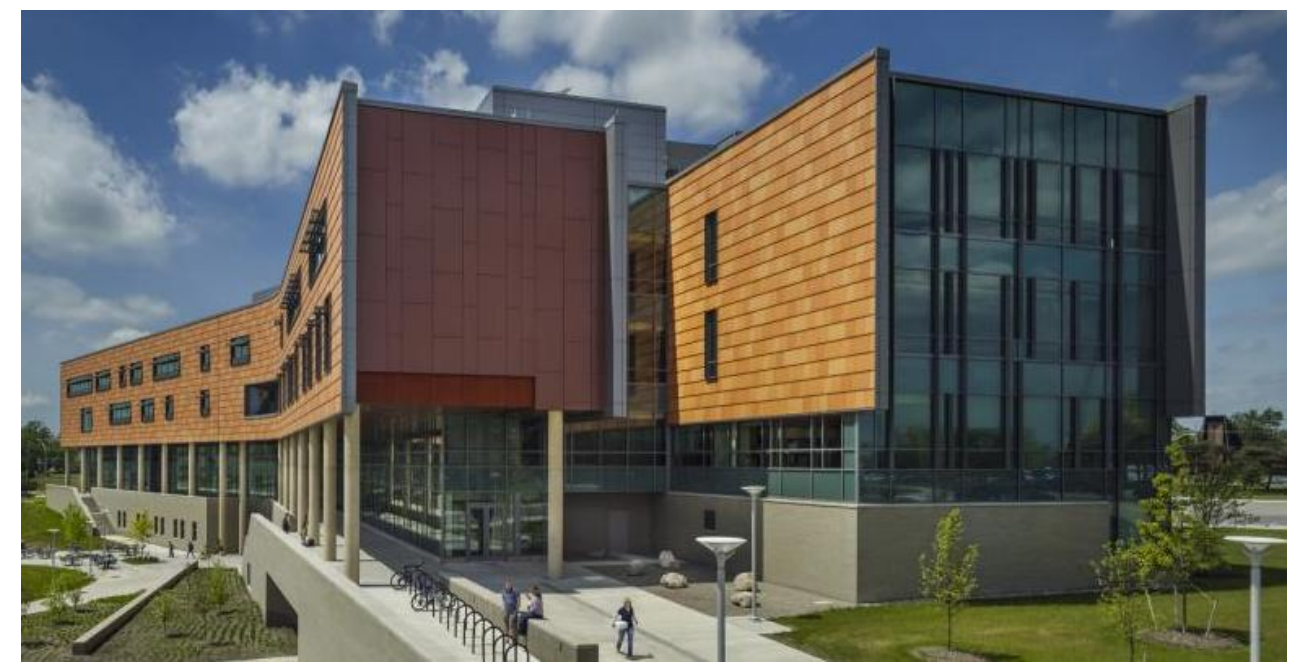

(a) Photo of the HHB building

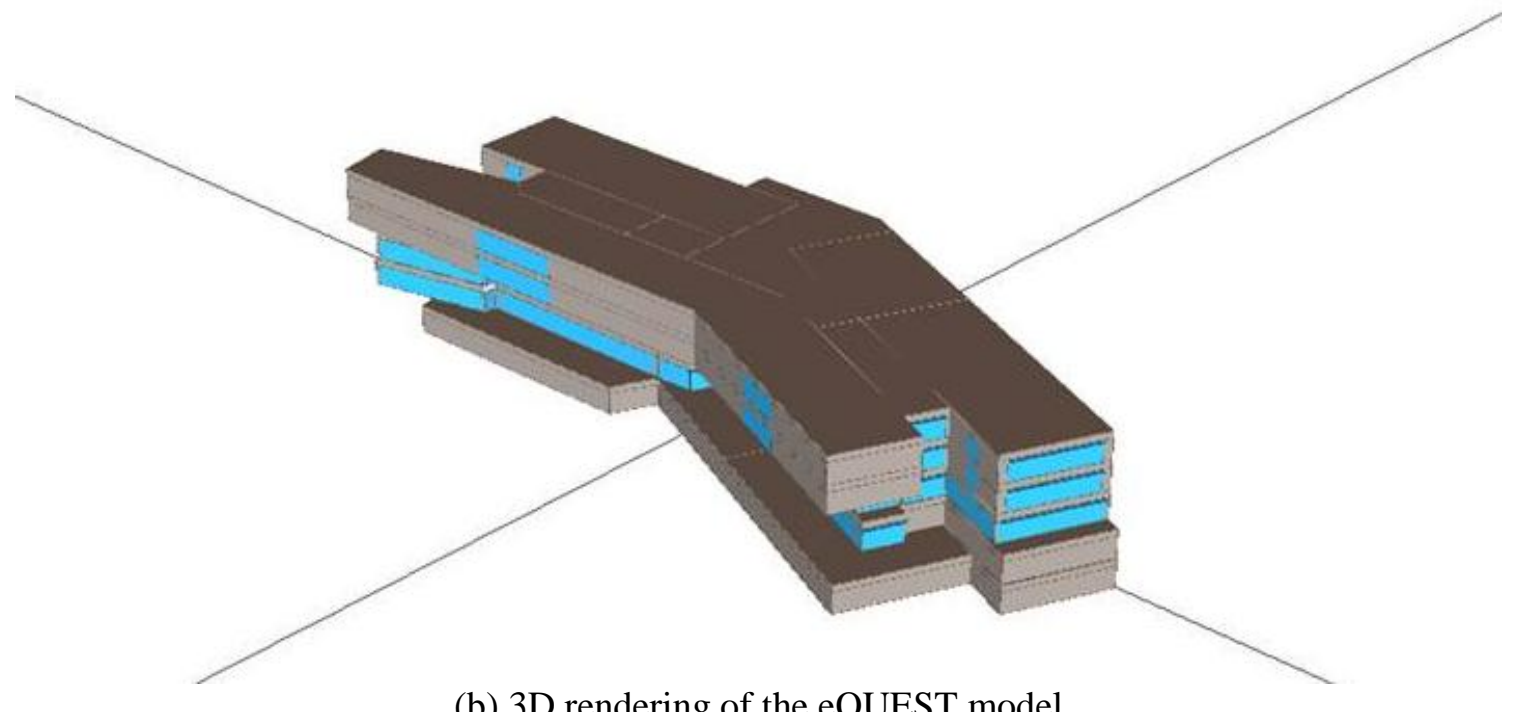

(b) 3D rendering of the eQUEST model

Figure 22. Three-dimensional rendering of the eQUEST model for the host building. 


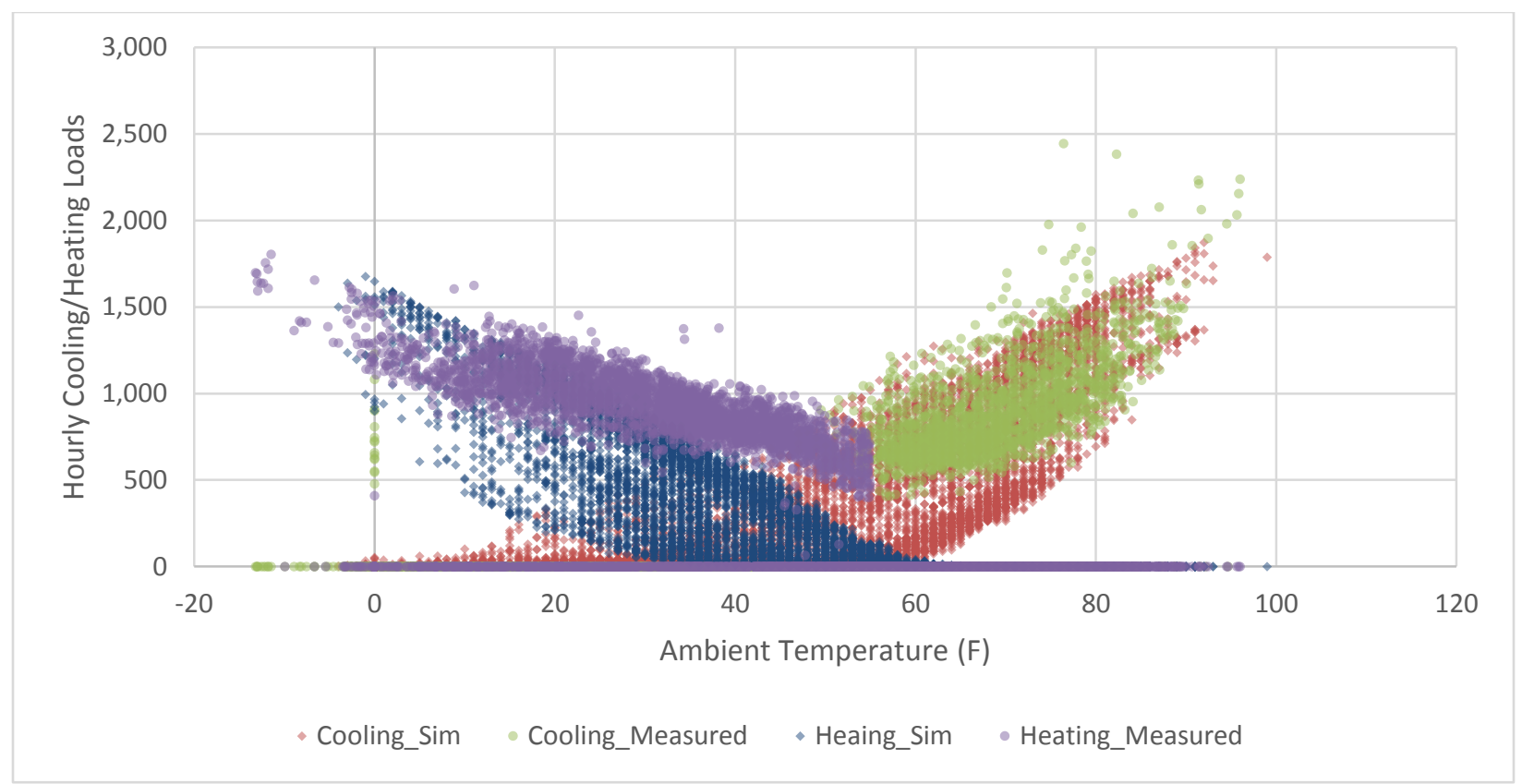

Figure 23. Hourly heating and cooling loads (measured vs. simulated) versus ambient air temperature.

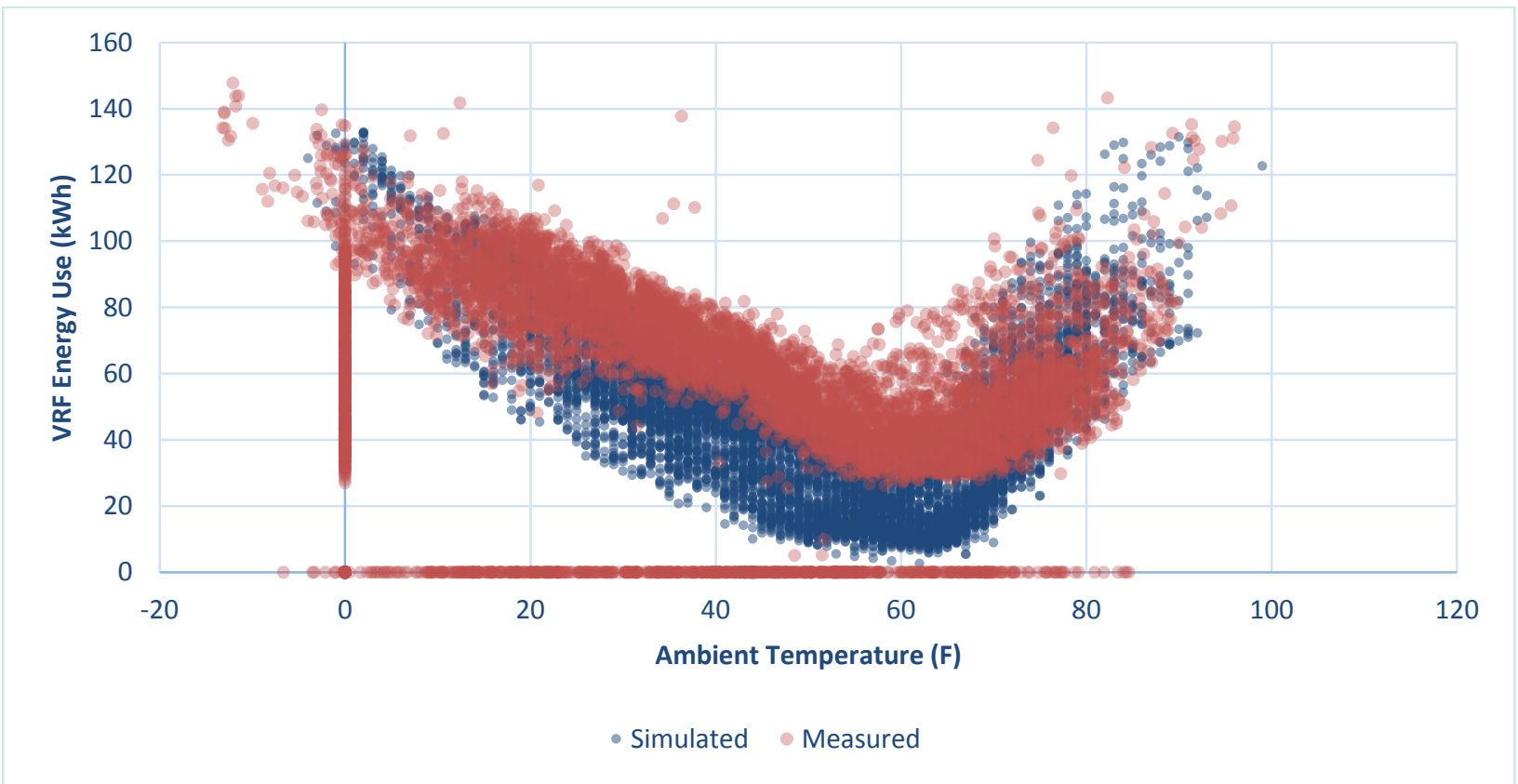

Figure 24. Hourly GS-VRF system energy use (measured vs. simulated) versus ambient air temperature.

\subsection{Baseline Energy Modeling}

Two baseline HVAC systems were considered for the economic analysis. Both baseline systems are variable-air-volume (VAV) systems with hot water reheat. An air-cooled chiller and a natural gas boiler were used in both baseline systems but with different efficiencies-minimum energy efficiencies as specified in ASHRAE Standard 90.1-2010 (ASHRAE 2010) in the first baseline and better efficiencies in 
the second baseline. Baseline models were developed by replacing the GS-VRF system in the calibrated model with each of the baseline systems. The assumptions for the two baseline models are as follows:

- Cooling energy efficiency ratio (EER) for the air-cooled chiller is 9.56 and 12.17 in the first and second baseline system, respectively.

- Thermal efficiency of the hot water boiler is $80 \%$ and $82 \%$ in the first and second baseline system, respectively.

- The zone supply air temperature is $55^{\circ} \mathrm{F}$, and the cold deck outdoor air reset schedule is applied to raise the zone entering temperature to $65^{\circ} \mathrm{F}$ when the ambient air temperature falls to $55^{\circ} \mathrm{F}$.

- The air-side economizer is used when ambient air temperature is below $65^{\circ} \mathrm{F}$.

- No heat or energy recovery was modeled in the baseline simulations.

Based on the simulation results for the baseline systems, the site energy, source energy, energy cost, and $\mathrm{CO}_{2}$ emissions of the baseline systems were calculated. The average utility rates paid by the university in 2013 and 2014 (i.e., $\$ 0.085 / \mathrm{kWh}$ for electricity and \$5.95/MMBtu for natural gas) were used for calculating energy cost savings. However, as listed in Table 6, while the electricity rate in 2013/2014 is only slightly (8\%) higher than that in 2009 when this project was planned, the natural gas rate in $2013 / 2014$ is $38 \%$ lower than in 2009.

Table 6. Electricity and natural gas rates paid by the university from 2008 to 2014

\begin{tabular}{lll}
\hline Year & $\begin{array}{l}\text { Electricity } \\
(\$ / K W H)\end{array}$ & $\begin{array}{l}\text { Natural gas } \\
\text { (\$/MMBTU) }\end{array}$ \\
\hline $\mathbf{2 0 0 8}$ & $\$ 0.0749$ & $\$ 9.442$ \\
$\mathbf{2 0 0 9}$ & $\$ 0.0761$ & $\$ 9.576$ \\
$\mathbf{2 0 1 0}$ & $\$ 0.0761$ & $\$ 9.691$ \\
$\mathbf{2 0 1 1}$ & $\$ 0.0791$ & $\$ 6.403$ \\
$\mathbf{2 0 1 2}$ & $\$ 0.0858$ & $\$ 6.913$ \\
$\mathbf{2 0 1 3}$ & $\$ 0.0881$ & $\$ 5.955$ \\
$\mathbf{2 0 1 4}$ & $\$ 0.0822$ & $\$ 5.850$ \\
\hline
\end{tabular}

The source energy factor for delivered electricity is 3.443, which is an average value for the US Eastern Interconnection, and the source energy factor for delivered natural gas is 1.092 according to Deru and Tocellini (2007). These conversion factors were used to calculate the source energy consumption. The same source provides the $\mathrm{CO}_{2}$ emission factors for delivered electricity- $1.64 \mathrm{lb}$ of pollutant per $\mathrm{kWh}$ of electricity, and for natural gas consumed on site- $122 \mathrm{lb}$ per $1 \mathrm{MMBtu}$ of natural gas on site burning emission factor and $11.6 \mathrm{lb}$ per $1 \mathrm{MMBtu}$ of natural gas pre-combustion emission factor. These conversion factors were used to calculate the $\mathrm{CO}_{2}$ emissions.

\subsection{Energy Savings Analysis}

Table summarizes the simulation and analysis results. Compared with the first baseline system, the GS-VRF system saved 6,919 MMBtu of source energy (a 33\% savings), \$29,627 in energy costs (23\% savings), and reduced about $627,151 \mathrm{lb}$ of $\mathrm{CO}_{2}$ emissions (a $25 \%$ reduction) annually. Compared with the more energy-efficient second baseline system, the GS-VRF system saved 5,691 MMBtu of source energy (a 29\% savings), \$21,245 in energy costs (17\% savings), and reduced about 470,347 lb of $\mathrm{CO}_{2}$ emissions (20\% reduction) annually. The full simulation reports for each baseline are provided in Appendix C. 
Table 7. Energy, cost, and $\mathrm{CO}_{2}$ savings for the case study building

\begin{tabular}{|c|c|c|c|}
\hline & $\begin{array}{c}\text { VRF } \\
\text { (Measured } \\
\text { w/ Simulated } \\
\text { Fan Energy) }\end{array}$ & $\begin{array}{c}\text { Base Case 1 } \\
\text { (VAV_NG Boiler } \\
\text { ASHRAE 90.1-2010) }\end{array}$ & $\begin{array}{c}\text { Base Case } 2 \\
\text { (VAV_NG Boiler } \\
\text { Better Efficiencies) }\end{array}$ \\
\hline & Electricity & Electricity Natural Gas & Natural Gas \\
\hline $\begin{array}{l}\text { HVAC Related Site Energy Use } \\
\text { (MMBtu) }\end{array}$ & 4,055 & 13,234 & 12,700 \\
\hline \% Difference vs. Baseline & & $69 \%$ & $68 \%$ \\
\hline $\begin{array}{l}\text { HVAC Related Source Energy } \\
\text { Use (MMBtu) }\end{array}$ & 13,961 & 20,880 & 19,652 \\
\hline \% Difference vs. Baseline & & $33 \%$ & $29 \%$ \\
\hline Energy Cost by fuel type & $\$ 101,017$ & $\$ 68,119 \quad \$ 62,525$ & $\$ 61,285 \quad \$ 60,977$ \\
\hline Total Energy Cost & $\$ 101,017$ & $\$ 130,644$ & $\$ 122,262$ \\
\hline Cost Savings & & $\$ 29,627$ & $\$ 21,245$ \\
\hline \% Difference vs. Baseline & & $23 \%$ & $17 \%$ \\
\hline $\mathrm{CO}_{2}$ Emissions (lb) by fuel type & $1,865,847$ & $1,258,198 \quad 1,234,800$ & $1,131,970 \quad 1,204,224$ \\
\hline Total $\mathrm{CO}_{2}$ Emissions (lb) & $1,865,847$ & $2,492,998$ & $2,336,194$ \\
\hline $\mathrm{CO}_{2}$ Emission Reductions (lb) & & 627,151 & 470,347 \\
\hline \% Difference vs. Baseline & & $25 \%$ & $20 \%$ \\
\hline
\end{tabular}

Figure 25 shows a comparison of the energy use intensities (EUIs) of the HVAC-related site and source energy for the GS-VRF system and the other two baseline systems. The benchmark EUIs for HVACrelated site energy for similar buildings were obtained from two references - the 2003 CBECS (EIA 2003) and the EPA Portfolio Manager (EPA 2014); these EUIs also are shown in Figure 25 for comparison. Note that the EUI from the 2003 CBECS data includes primary and secondary schools as well, which typically have lower EUIs than university buildings. The EUI from the EPA Portfolio Manager is the average of the EUIs of existing university buildings, which would be higher than the EUI of the new building. As can be seen from Figure 25, the predicted site EUI of the two baseline systems is reasonably close to the benchmark EUIs, and the site EUI of the GS-VRF system is less than half of the benchmark EUIs.

For further comparison, Figures 26 and 27 compare the site and source energy end use between the GS-VRF system and the two baseline systems. Since the GS-VRF system provides both space heating and cooling, the corresponding energy consumptions are combined into one category. As shown in these figures, the lighting and equipment energy use are the same for all three cases; and while GS-VRF consumes much less energy for space cooling and heating, it uses more energy for the pump and fans than the baseline systems. Figure 27 shows that the source energy use by the GS-VRF for cooling and heating is about 61\% (i.e., 10,308 MMBtu) and 58\% (i.e., 9,103 MMBtu) lower, respectively, than that of the two baseline systems. However, the source energy use of the indoor fans and the circulation pumps of the GS-VRF system is about 62\% (3,231 MMBtu) and 53\% (1,126 MMBtu) higher, respectively, than that in the baseline systems. The result is a moderate (29-33\%) source energy savings by the GS-VRF system. 


\section{TOTAL SITE/SOURCE HVAC EUI}

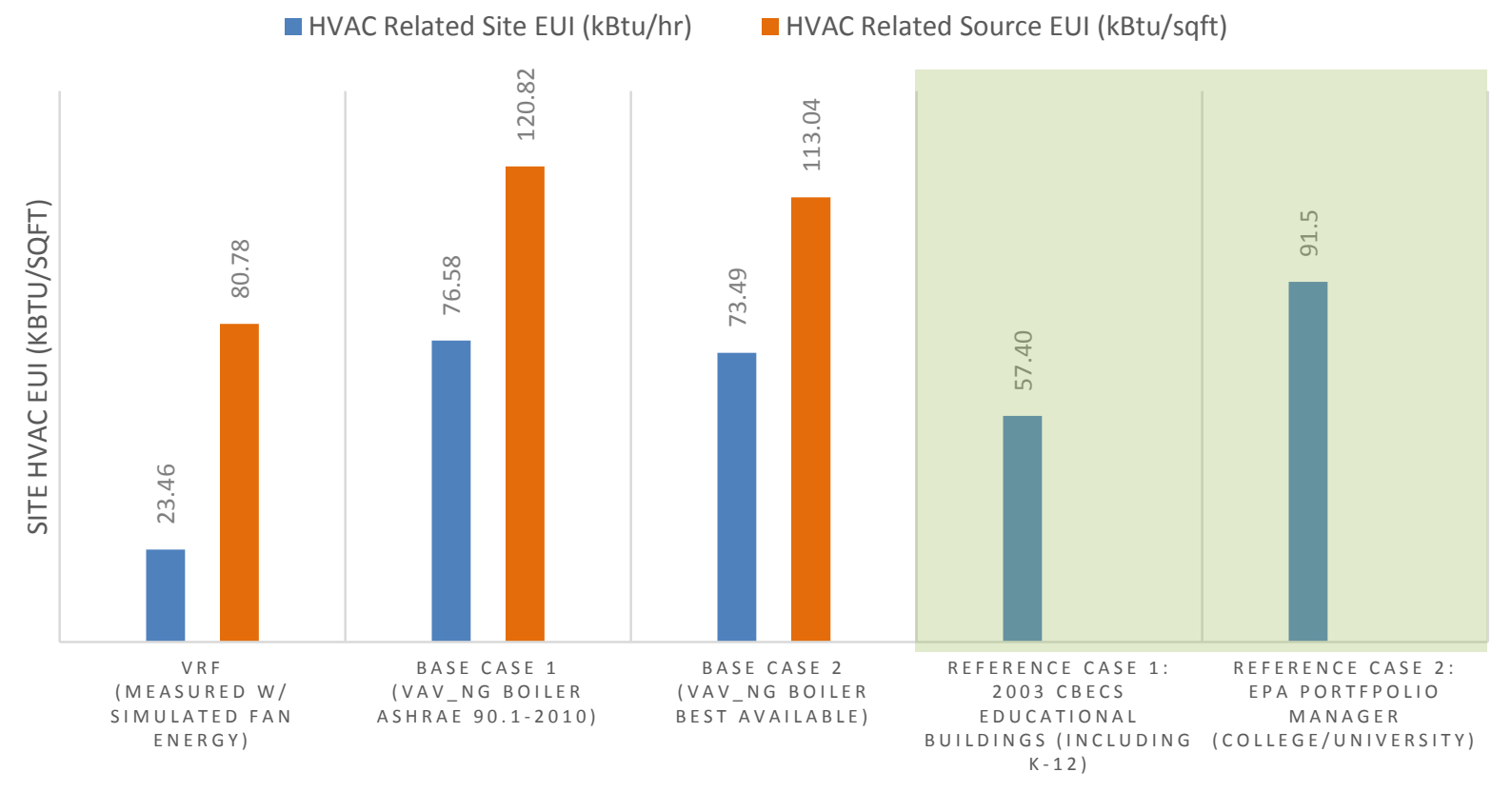

Figure 25. Comparisons of the site and source HVAC energy.

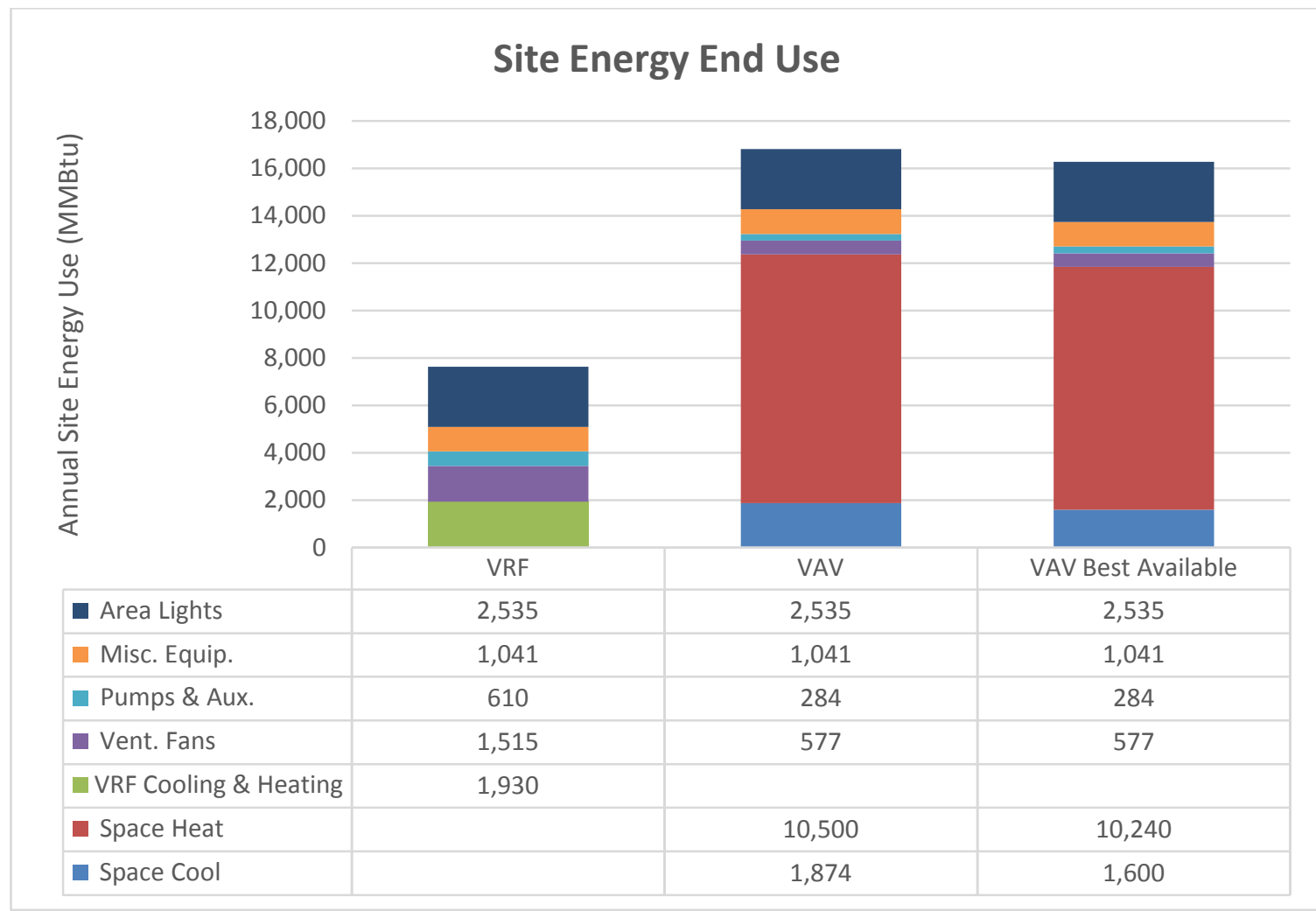

Figure 26. Comparisons of site energy end use between GS-VRF and two baseline systems. 


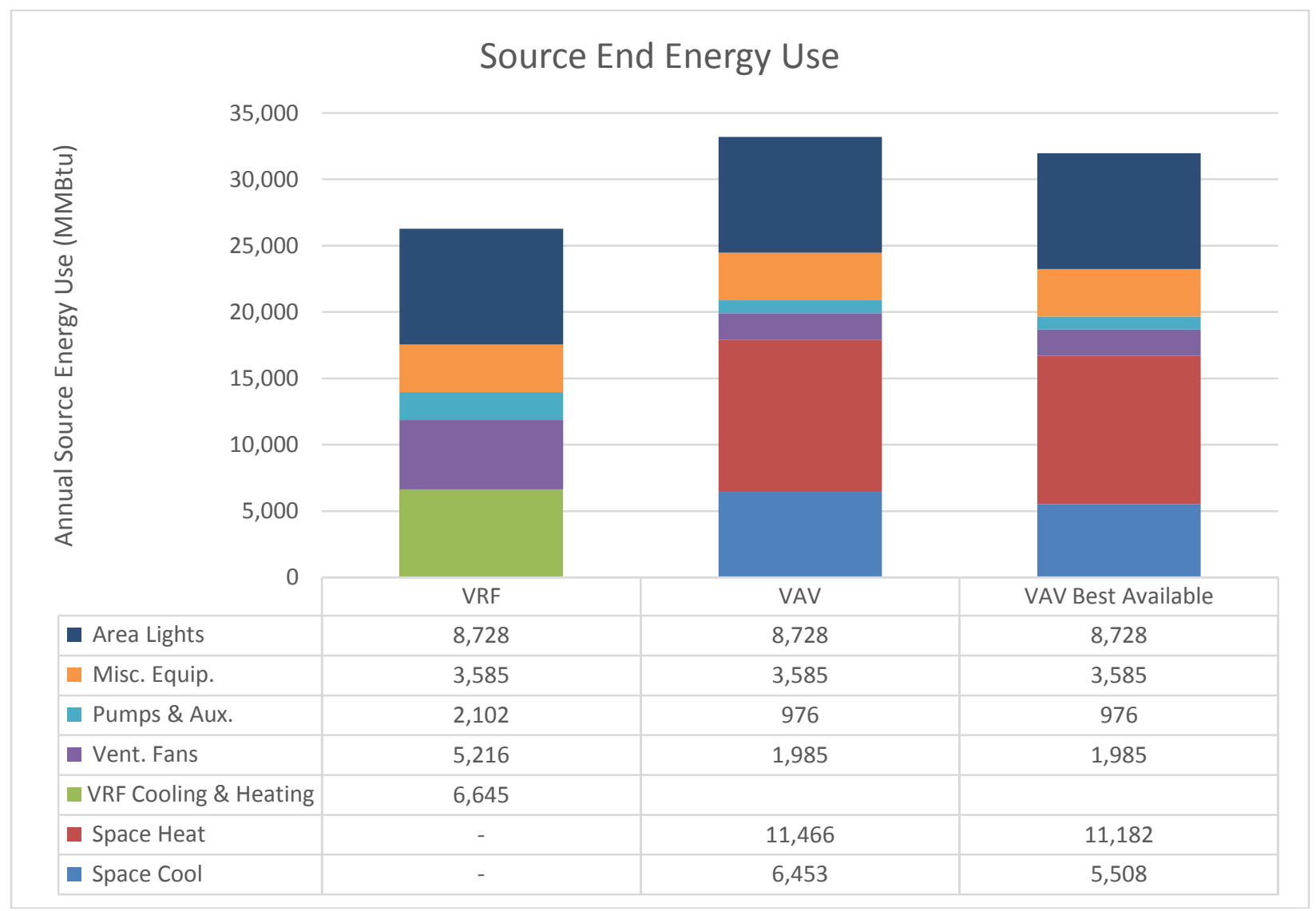

Figure 27. Comparisons of source energy end use between GS-VRF and two baseline systems.

\subsection{Cost Analysis}

The GS-VRF system cost premium is the difference between the installed cost of the GS-VRF system and the cost of the baseline system. Tables 8 and 9 summarize the itemized costs of the demonstrated GS-VRF system and the baseline system, which are provided by the grantee (Oakland University). The total installed costs of the GS-VRF system and the baseline system are $\$ 7,540,083$ and $\$ 6,728,778$, respectively. The resulting cost premium of the GS-VRF system is $\$ 811,305$.

Given the 440 ton installed cooling capacity of the GS-VRF system and the $172,000 \mathrm{ft}^{2}$ building floor space, the installed cost can be normalized as $\$ 17,137$ per installed cooling ton, or $\$ 43.8$ per square foot of building floor space.

As listed in Table 7, the GS-VRF system saved \$29,627 (23\% saving) and \$21,245 (17\% saving) in energy costs compared with the first and second baseline systems, respectively.

Based on the calculated cost premium $(\$ 811,305)$ and the predicted annual operating cost savings of the GS-VRF system, the simple payback periods for the GS-VRF system are 27 and 38 years compared with the first and second baseline systems, respectively. However, if the energy cost savings were calculated with the 2009 utility rates, the simple payback periods would have been 11 and 13 years, respectively. 
It should also be noted that the demonstrated GS-VRF system is a part of a very complicated system serving the building. It is likely that the complexity of the system may have increased the costs for system design, installation, and integration.

Table 8. Itemized installed cost of the demonstrated GS-VRF system

\begin{tabular}{|l|l|r|}
\hline \multicolumn{2}{|c|}{ Cost items } & Costs (\$) \\
\hline Well field & Geothermal field & $1,213,557$ \\
\hline \multirow{3}{*}{} & Ductwork & $2,459,678$ \\
\cline { 2 - 3 } & Piping & 900,250 \\
\cline { 2 - 3 } & VRF equipment & 810,700 \\
\cline { 2 - 3 } & Ground source heat pump chiller & 145,040 \\
\cline { 2 - 3 } & Boiler & 17,000 \\
\cline { 2 - 3 } & Heat exchangers & 20,500 \\
\cline { 2 - 3 } & Pumps & 119,000 \\
\cline { 2 - 3 } & Test and balance & 215,775 \\
\hline \multirow{2}{*}{ Others } & Electric & $1,4997,37$ \\
\cline { 2 - 3 } & Integration & 888,715 \\
\hline Subtotal direct costs & $\mathbf{7 , 5 4 0 , 0 8 3}$ \\
\hline
\end{tabular}

Table 9. Itemized installed cost of the baseline system

\begin{tabular}{|c|c|c|c|c|}
\hline Name & Unit Cost & \# of Units & Cost & Notes \\
\hline AHU $(26,000$ CFM $)$ & $\$ 157,000$ & 10.00 & $\$ 1,570,000$ & $\begin{array}{l}\text { From RS Means Facilities Construction } \\
\text { Cost Data } 2012\end{array}$ \\
\hline Chillers (210 Tons) & $\$ 166,000$ & 2.00 & $\$ 332,000$ & $\begin{array}{l}\text { From RS Means Facilities Construction } \\
\text { Cost Data } 2012\end{array}$ \\
\hline Cooling Towers & $\$ 24,000$ & 3.00 & $\$ 72,000$ & $\begin{array}{l}\text { From RS Means Facilities Construction } \\
\text { Cost Data } 2012\end{array}$ \\
\hline Boilers $(4,000 \mathrm{MBH})$ & $\$ 44,500$ & 3.00 & $\$ 133,500$ & $\begin{array}{l}\text { From RS Means Facilities Construction } \\
\text { Cost Data } 2012\end{array}$ \\
\hline Ductwork & $\$ 2,302,569$ & 1.00 & $\$ 2,302,569$ & $\begin{array}{l}\text { HHB Cost, deducted } \$ 518,000 \text { for DOAS } \\
\text { units, and adjusted for additional ductwork }\end{array}$ \\
\hline VAV & $\$ 111,000$ & 1.00 & $\$ 111,000$ & Estimated 111 zones x $\$ 1,000$ per zone \\
\hline Pumps & $\$ 119,000$ & 1.00 & $\$ 119,000$ & Same as HHB cost \\
\hline Piping & $\$ 900,250$ & 0.50 & $\$ 450,125$ & $50 \%$ of HHB cost \\
\hline Electrical & $\$ 1,499,737$ & 0.50 & $\$ 749,869$ & $50 \%$ of HHB cost \\
\hline Integration & $\$ 888,715$ & 1.00 & $\$ 888,715$ & Same as HHB cost \\
\hline Total Base Cost & \multicolumn{3}{|c|}{$\$ 6,728,778$} & $\$ 39.12 / \mathrm{ft}^{2}$ \\
\hline
\end{tabular}




\section{OPERATION AND MAINTENANCE}

According to the Oakland University facility manager, the HHB has operated well since its opening in August 2012, and there have been significantly fewer complaints for the HHB than for other buildings (180 per year instead of 300 per year on average), The Work Order Browse Report for the HHB was analyzed to identify HVAC-related complaints, maintenance/repair issues, and the associated costs. There are three types of complaints/requests in the report: too cold, too hot, and repair/maintenance. Usually complaints that the building was too cold or too hot were solved by adjusting thermostat settings. However, it has been found that temperatures in a few zones cannot be maintained at set points by the indoor FCUs because of some control issues associated with switching between heating and cooling modes for the FCUs. The requested repair/maintenance is filter changes. A summary of the total number and cost of maintenance for HVAC-related complaints is shown in Figure 28.

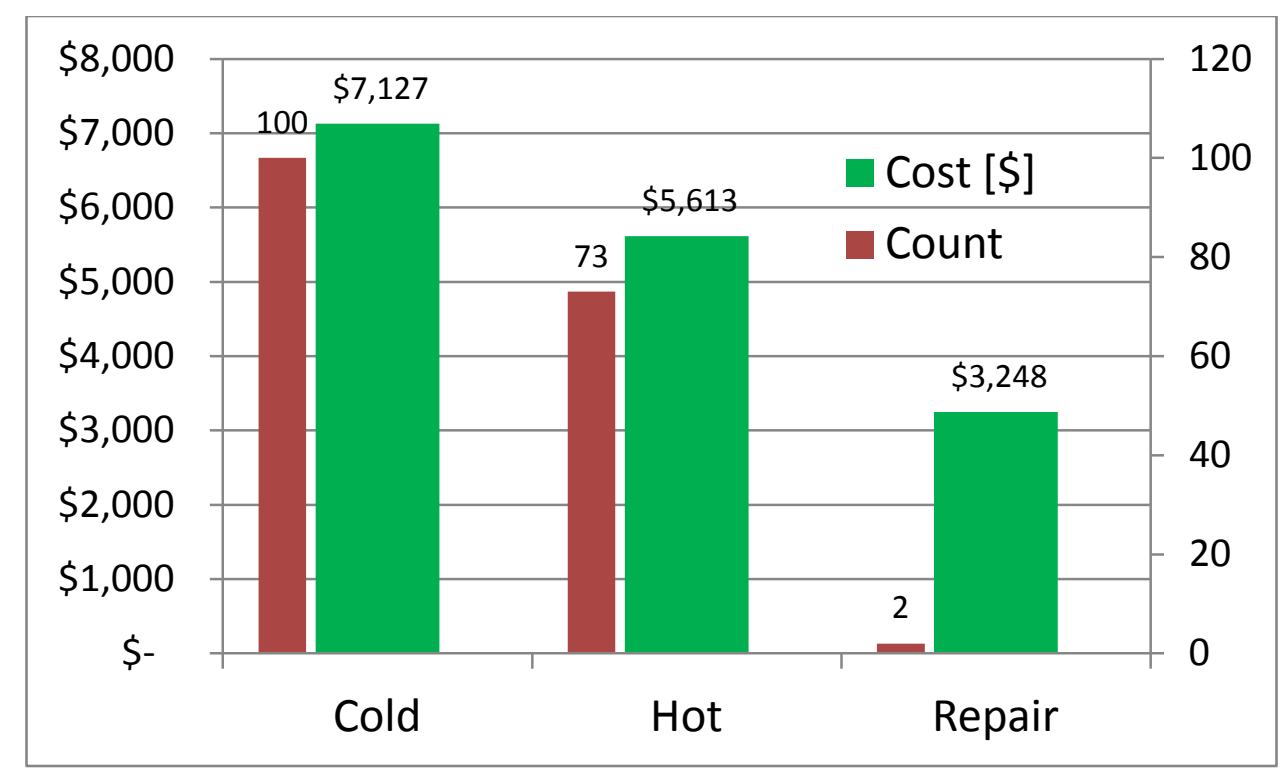

Figure 28. Summary of the costs and counts of maintenance requests for HVAC-related issues. 


\section{CONCLUSIONS AND LESSONS LEARNED}

The performance, achieved benefits, and cost-effectiveness of a GS-VRF system installed at the HHB at Oakland University in Rochester, Michigan, was investigated in this case study. The investigation is based on the analysis of measured performance data, maintenance records, construction costs, and calibrated building energy simulations. The following are major findings and lessons learned from this case study.

- The site EUI of the demonstrated GS-VRF system is less than half of the comparable benchmark EUIs for HVAC-related site energy of similar buildings.

- The GS-VRF system saved 6,919 MMBtu source energy (a 33\% savings), avoided \$29,627 energy costs (23\% savings), and reduced $627,151 \mathrm{lb}$ of $\mathrm{CO}_{2}$ emissions (a $25 \%$ reduction) annually compared with a conventional VAV system that uses minimum code-compliant air-cooled chiller and natural-gas boiler.

- The simple payback period of the GS-VRF system is 27 years compared with a conventional VAV system that uses minimum code-compliant air-cooled chiller and natural-gas boiler. However, if the utility rates were at its 2009 level, the simple payback period would have been 11 years.

- The ground heat exchanger of the GS-VRF system maintained the fluid temperature supplied to the VRF units within 50 to $70^{\circ} \mathrm{F}$ during the full-year period encompassed in this study, while the ambient temperature varied from -18 to $96^{\circ} \mathrm{F}$. The 50 to $70^{\circ} \mathrm{F}$ fluid temperatures enable efficient operation of the VRF units.

- The building served by the GS-VRF system has been operating well since it was commissioned in August 2012, and it received $40 \%$ fewer complaints compared with other buildings on campus.

- The operational efficiency of the GS-VRF system could be even better if following control issues are solved:

○ It was found that the water flow to each water source VRF unit was not regulated. As a result, the variable-speed pump of the common water loop ran at speeds within a narrow range all year long, more like a constant-speed pump, and the temperature differential at the water loop is very small, especially in the winter. It is recommended that water flow rate in each VRF unit be modulated with an effective strategy (e.g., maintaining a constant differential temperature at each VRF unit) to avoid excessive flow and the resulting waste of pumping energy.

- The fan speed of FCUs is constant whenever the FCU runs in either heating or cooling mode. Since FCUs of the VRF system can adjust their capacities by modulating the refrigerant flow, they could run in heating or cooling mode for a long time with low capacities. The constantspeed fan operation has contributed $33 \%$ of the annual power consumption of the GS-VRF system! It is recommended that the fan speed of each FCU be modulated according to the heating/cooling demand of the zone that the FCU serves. This action has potential to reduce fan energy consumption by $62 \%$ (to the same level of the VAV system).

- Conflicting simultaneous heating and cooling in adjacent zones of the building has been observed. This is a result of the precise temperature control of the VRF system, which can maintain the room temperature within a very narrow range (i.e., $0.5^{\circ} \mathrm{F}$ ) from its set point by providing the needed heating or cooling. However, since the set points in adjacent zones could be different, the precise room temperature control resulted in some FCUs running in cooling mode while others were running in heating mode. This conflicting simultaneous heating and cooling artificially increased building loads and resulted in unnecessary energy consumption. It is recommended that a better control strategy be developed to reduce/eliminate the conflicting simultaneous heating and cooling operation in adjacent zones. 


\section{REFERENCES}

ASHRAE. 2010. Standard 90.1-2010 - Energy Standard for Buildings Except Low-Rise Residential Buildings. Atlanta, GA: American Society of Heating, Refrigerating and Air Conditioning Engineers.

Daikin, LLC. 2014. VRV Modeling with EQuest. Retrieved from http://www.daikinac.com/content/assets/Energy-Modeling-Files/DaikineQuest.pdf (accessed December $18,2014)$.

Deru, M., and P. Tocellini. 2007. Source Energy and Emission Factors for Energy Use in Buildings, Technical Report NREL/TP-550-38617, National Renewable Energy Laboratory.

EIA (US Energy Information Administration). 2003. Commercial Buildings Energy Consumption Survey (CBECS), Energy Information Administration, Washington, D.C. Retrieved from https://catalog.data.gov/dataset/commercial-buildings-energy-consumption-survey (accessed December 2014).

EPA (US Environmental Protection Agency). 2014. ENERGY STAR Portfolio Manager, Environmental Protection Agency, Washington, D.C. Retrieved from http://www.energystar.gov/buildings/facilityowners-and-managers/existing-buildings/use-portfolio-manager (accessed December 2014).

Hirsch, Jeff, et al. 2013. eQUEST (Quick Energy Simulation Tool) Version 3.64 (available at www.doe2.com).

Southard, L. E., X. Liu, and J. D. Spitler. 2014. "Performance of HVAC systems at ASHRAE HQ: Part one," ASHRAE Journal 56(9), 14-24. 


\section{APPENDIX A. VRF UNIT ENERGY CONSUMPTION}
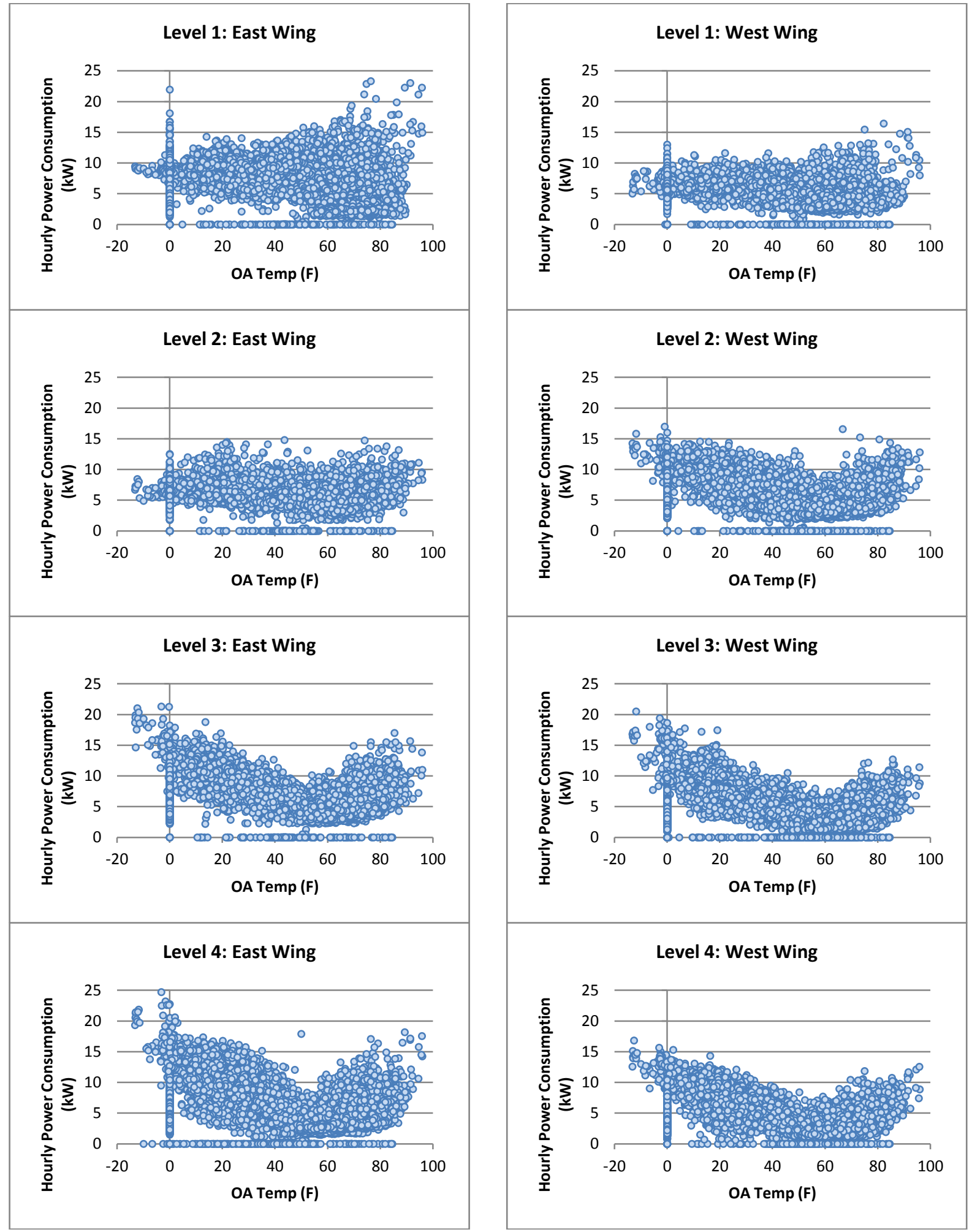

Figure A-1. VRF unit energy consumption per floor and wing. 



\section{APPENDIX B. BMS SCREENSHOTS FOR ZONE SET POINT TEMPERATURE, ZONE TEMPERATURE, AND VRF MODE}

\begin{tabular}{|c|c|c|c|c|c|c|c|c|c|c|c|c|c|c|}
\hline \multicolumn{3}{|c|}{ Oakland University } & \multicolumn{4}{|c|}{ HHB Zone Summary } & \multicolumn{4}{|c|}{ Time \& Date 18-Aug-14 13:02: OA Tmp } & OARH 9 & OAE & Enth 0.7 & \multirow[b]{2}{*}{$\begin{array}{l}\text { A FC5045-2 } \\
\text { (1) } 70.7\end{array}$} \\
\hline $\begin{array}{l}\text { A FC1003C } \\
\text { (T } 73.6 \\
75.0\end{array}$ & $\begin{array}{l}\text { A FC1031 } \\
\text { (1) } 72.5 \\
72.01\end{array}$ & 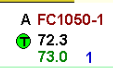 & $\begin{array}{l}\text { A FC2008 } \\
\Theta 72.8 \\
74.0 \quad 1\end{array}$ & $\begin{array}{l}\text { A FC2046 E } \\
\text { (1) } 71.5 \\
73.01\end{array}$ & $\begin{array}{c}\text { :NT A FC2085 } \\
\text { (T) } 72.6 \\
73.01\end{array}$ & 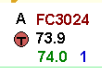 & 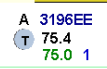 & $\begin{array}{l}\text { A FC3117 } \\
\text { (1) } 71.8 \\
71.01\end{array}$ & $\begin{array}{l}\text { A FC4001-1 } \\
\text { (T) } 75.2 \\
75.01\end{array}$ & $\begin{array}{l}\text { A FC4031-1 } \\
\text { T) } 74.4 \\
74.01\end{array}$ & $\begin{array}{c}\text { - FC4050-1 } \\
\text { (1) } 73.4 \\
73.01\end{array}$ & $\begin{array}{l}1 \text { A FC4194C } \\
\text { (I) } 74.7 \\
75.0 \quad 1\end{array}$ & $\begin{array}{l}\text { A FC5025-2 } \\
\text { (T) } 74.6 \\
71.02\end{array}$ & \\
\hline $\begin{array}{l}\text { A FCC1004 } \\
\text { ( } 71.5\end{array}$ & $\begin{array}{l}\text { A FC1040A } \\
\text { A } 73.4\end{array}$ & $\begin{array}{l}\text { A FC1050-2 } \\
\text { (1) } 71.2\end{array}$ & $\begin{array}{l}\text { A F C22009 } \\
\text { O } 74.1\end{array}$ & $\begin{array}{l}\text { A FC2048-1 } \\
\text { (ब) } 72.5\end{array}$ & $\begin{array}{l}1 \text { FC2086 } \\
\text { \& } 73.1\end{array}$ & $\begin{array}{l}\text { A FC3026 } \\
\text { (4) } 73.3\end{array}$ & $\begin{array}{l}\text { A FC3070 } \\
\text { (t) } 71.6\end{array}$ & $\begin{array}{l}\text { A FC3118 } \\
\text { (T) } 72.5\end{array}$ & $\begin{array}{l}\text { A FC4001-2 } \\
\text { (i) } 74.9\end{array}$ & A FC4032 & $\begin{array}{l}\text { A FCA } 7050-2 \\
\text { (I) } 73.3\end{array}$ & $\begin{array}{l}2 \text { A FC4196E } \\
\text { (t) } 74.4\end{array}$ & $\begin{array}{l}\text { A FC5061 } \\
\text { T) } 72.1^{7.1}\end{array}$ & $\begin{array}{l}\text { A F } 50050-1 \\
\text { (1) } 74.1\end{array}$ \\
\hline $\begin{array}{l}\text { A FCC1005-1 } \\
\text { A } 72.0 \quad 1 \\
74.0\end{array}$ & 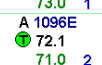 & $\begin{array}{l}\text { A FC 1.050-3 } \\
\text { A } 72.3 \\
73.0\end{array}$ & 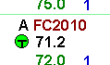 & 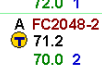 & 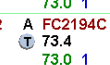 & 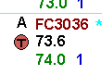 & $\begin{array}{l}71.01 \\
\text { A FC3073 } \\
\text { (T) } 74.1 \\
72.01\end{array}$ & 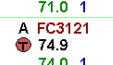 & $\begin{array}{l}74.01 \\
\text { A FC4005-1 } \\
\text { क } 73.1\end{array}$ & $\begin{aligned} 7.202 \\
\text { A FC4081 } \\
\text { T T } 73.8\end{aligned}$ & $\begin{array}{rl}73.0 & 1 \\
\text { A FC4065 } \\
\text { (ब) } 72.3\end{array}$ & 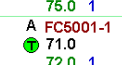 & $\begin{array}{rl}73.01 & 1 \\
\text { A F F } 5094 \mathrm{C} \\
\mathbb{T} 74.4\end{array}$ & $\begin{array}{rl}74.01 & 1 \\
\text { A FC605-2 } \\
\text { (T) } 74.6\end{array}$ \\
\hline $\begin{array}{l}\text { A FC1005-2 } \\
\text { (i) } 71.8\end{array}$ & $\begin{array}{l}\text { A F F } 102 \\
\text { A } 71.20-2 \\
71.2\end{array}$ & $\begin{array}{l}7.01 \\
\text { A FC1051 } \\
\text { (i) } 72.6\end{array}$ & 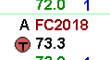 & $\begin{array}{l}70.02 \\
\text { A FC2094C } \\
\text { TI } 74.1\end{array}$ & $\begin{array}{l}\text { 73.01 } \\
\text { A FC2196E } \\
\text { T } 73.9\end{array}$ & $\begin{array}{l}74.01 \\
\text { A FC3037 } \\
\text { o } 75.7\end{array}$ & $\begin{array}{l}72.01 \\
\text { A FC3077 } \\
\text { () } 72.8\end{array}$ & $\begin{array}{l}\text { A4.0 1 } \\
\text { A FC3124 } \\
\text { () } 73.3\end{array}$ & $\begin{array}{l}7.01 \\
\text { A FC4005-2 } \\
\text { (i) } 73.3\end{array}$ & 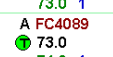 & $\begin{array}{l}73.01 \\
\text { A FC4067 } \\
\text { (i) } 72.3\end{array}$ & $\begin{array}{l}72.01 \\
\text { A F } 50001-2 \\
\text { ब } 71.5\end{array}$ & $\begin{aligned} & 75.01 \\
& \text { A FC5096E } \\
& \Theta 75.7\end{aligned}$ & $\begin{array}{l}74.01 \\
\text { A F } 505054-1 \\
\text { (1) } 74.9\end{array}$ \\
\hline $\begin{array}{l}\text { A FC1006-1 } \\
\text { (1) } 71.5 \text { cale }\end{array}$ & $\begin{array}{l}\text { A } 1.022 \\
\text { A F } 74.4040-1 \\
7.4\end{array}$ & $\begin{array}{l}\text { A FC10 } 1051 \mathrm{~A} \\
\mathbb{\Theta} 72.1\end{array}$ & 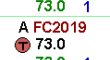 & $\begin{array}{rl}75.01 & 1 \\
\text { A FC2096E } \\
\mathbb{I} 75.9\end{array}$ & $\begin{array}{l}75.01 \\
\text { A A } 30001 \\
\Theta 04.7\end{array}$ & $\begin{array}{l}75.01 \\
\text { A C C } 04044 \\
\text { T } 75.1\end{array}$ & $\begin{array}{rl}73.01 & 1 \\
\text { A FC3082 } \\
\text { (1) } 74.0\end{array}$ & $\begin{array}{l}74.01 \\
\text { A FC3125 } \\
\text { (4) } 74.4\end{array}$ & $\begin{aligned} 73.01 \\
\text { A FC4006 } \\
\text { क } 73.0\end{aligned}$ & $\begin{aligned} 74.01 \\
\text { A } 4094 \mathrm{C} \\
\mathbb{\mathrm { I }} 74.1\end{aligned}$ & $\begin{array}{rl}73.01 & 1 \\
\text { A FC } & \text { FC609 } \\
\text { (T) } 73.0\end{array}$ & $\begin{array}{l}72.01 \\
\text { A FC5002-1 } \\
\text { ब } 73.6\end{array}$ & $\begin{array}{rl}75.01 & 1 \\
\text { A FC5025.3 } \\
\text { () } 74.6\end{array}$ & $\begin{array}{l}76.01 \\
\text { A FC5054-2 } \\
\text { (T) } 74.6\end{array}$ \\
\hline $\begin{array}{rl}72.0 & 1 \\
\text { A FC1006-2 }\end{array}$ & $\begin{array}{l}75.01 \\
\text { A } 1094 \mathrm{C}\end{array}$ & $\begin{array}{rl}73.0 & 1 \\
\text { A FC1052 }\end{array}$ & $\begin{array}{c}73.0 \quad 1 \\
\text { A FC2023-1 }\end{array}$ & $\begin{array}{r}75.01 \\
\text { A FC2050 }\end{array}$ & $\begin{array}{r}75.01 \\
\text { A FC3003 }\end{array}$ & $\begin{array}{r}75.01 \\
\text { A FC3045 }\end{array}$ & $\begin{array}{r}72.02 \\
\text { A FC3091 }\end{array}$ & $\begin{array}{r}74.01 \\
\text { A FC3135 }\end{array}$ & $\begin{array}{r}73.01 \\
\text { A FC4015 }\end{array}$ & $\begin{array}{l}74.01 \\
\text { I } 4096 \mathrm{E}\end{array}$ & $\begin{array}{r}73.01 \\
\text { A FC } 4070\end{array}$ & $\begin{array}{c}73.01 \\
\text { A FC5002-2 }\end{array}$ & $\begin{array}{r}74.01 \\
\text { A FC5030 }\end{array}$ & $\begin{array}{r}76.0 \quad 1 \\
\text { A FC5060 }\end{array}$ \\
\hline $\begin{array}{c}72.5 \\
72.0 \\
72\end{array}$ & $\begin{array}{c}₫ 74.4 \\
75.0\end{array}$ & $\begin{array}{l}\text { (T) } 70.8 \\
70.0 \quad 1\end{array}$ & $\begin{array}{l}0.63 .6 \\
73.0\end{array}$ & $\begin{array}{l}70.0 \\
70.01\end{array}$ & $\begin{array}{l}\Theta_{73.01}^{73.8} \\
73\end{array}$ & (7) 74.4 & $\begin{array}{l}4 \\
-73.0 \\
72.01\end{array}$ & $\begin{array}{l}\text { A } 70.7 \\
71.01\end{array}$ & $\begin{array}{l}\text { (1) } 72.0 \\
73.01\end{array}$ & $\begin{array}{l}\text { I } 82.2 \\
73.0\end{array}$ & (1) $\begin{array}{l}73.8 \\
73.0\end{array}$ & (1) 73.0 & $\begin{array}{l}0 \\
70.5\end{array}$ & $\begin{array}{l}\text { (1) } 73.3 \\
73.01\end{array}$ \\
\hline $\begin{array}{l}\text { A FC } 1012 \\
\text { (i) } 74.2 \\
74.2\end{array}$ & $\begin{array}{l}\text { A } 1057 \mathrm{1} \\
\text { (7 } 73.4\end{array}$ & $\begin{array}{l}\text { A FC10103 } \\
\text { T) } 71.3\end{array}$ & 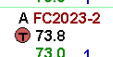 & $\begin{array}{l}\text { A F } 202054 \\
\text { (T) } 72.8\end{array}$ & $\begin{array}{l}\text { A FC3006 } \\
\text { ब } 75.9\end{array}$ & $\begin{array}{l}\text { A } F \text { FC3053 } \\
\text { (3) } 75.4\end{array}$ & $\begin{array}{l}\text { A FC3092 } \\
\text { F } 73.09\end{array}$ & $\begin{array}{l}\text { A FC3146 } \\
\text { (A) } 73.6\end{array}$ & $\begin{array}{l}\text { A FCC4018-1 } \\
\text { (i) } 75.9\end{array}$ & $\begin{array}{l}\text { A FC4031-2 } \\
\text { I } 74.1\end{array}$ & $\begin{array}{l}\text { A F F C } 071 \\
\text { (A) } 72.0\end{array}$ & $\begin{array}{l}\text { A FC5004 } \\
\text { (T) } 72.8\end{array}$ & $\begin{array}{l}\text { A F F } 5035-1 \\
A 72.3\end{array}$ & $\begin{array}{l}\text { A FCG6008E } \\
\text { (7) } 74.7\end{array}$ \\
\hline $\begin{array}{l}\text { A FC1014 } \\
\text { A) } 71.0 \\
72.0\end{array}$ & $\begin{array}{l}\text { A } 1066 \mathrm{C} \\
\text { đ } 75.2 \\
750\end{array}$ & $\begin{array}{l}\text { A FC } 1054 \\
\text { (ब) } 74.4\end{array}$ & $\begin{array}{l}\text { A F F } 2024 \\
\text { Ai } 73.0\end{array}$ & $\begin{array}{l}\text { A F F } 2055 \\
\text { (7) } 72.8\end{array}$ & $\begin{array}{l}\text { A FC3009 } \\
\text { T } 75.4\end{array}$ & $\begin{array}{l}\text { A } 153054 \\
\text { O } 75.2\end{array}$ & $\begin{array}{l}\text { A FC3103 } \\
\text { (4) } 72.1\end{array}$ & $\begin{array}{l}\text { A FC3152 } \\
\text { (1) } 72.6\end{array}$ & $\begin{array}{l}\text { A FCA } 1818-2 \\
\text { (1) } 73.6\end{array}$ & $\begin{array}{l}\text { A FC4031.3 } \\
\text { O } 74.1\end{array}$ & $\begin{array}{l}\text { A } F 4074 \\
\text { (t) } 73.1\end{array}$ & $\begin{array}{l}\text { A FC5015 } \\
\text { (T) } 73.4 .4\end{array}$ & 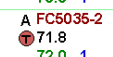 & $\begin{array}{l}\text { A 5 5194C } \\
\text { (T } 74.9\end{array}$ \\
\hline 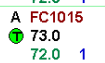 & $\begin{array}{l}\text { A } 1194 \mathrm{C} \\
\text { T) } 74.6 \\
75.0 \quad 1\end{array}$ & 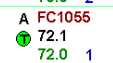 & $\begin{array}{l}\text { A F C2030 } \\
\text { A } 73.4 \\
73.0\end{array}$ & 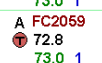 & 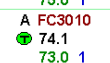 & 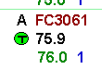 & 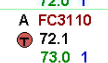 & $\begin{array}{l}\text { A FC311 } \\
\text { (t) } 72.5 \\
720\end{array}$ & $\begin{array}{l}\text { A FCA } 18-\mathrm{A} \\
\text { (i) } 73.0\end{array}$ & $\begin{array}{l}\text { A F F C } 1041 \\
\text { O } 71.8\end{array}$ & $\begin{array}{l}\text { A FC4074 } \\
\text { A F } 73.0\end{array}$ & $\begin{array}{l}\text { A FC501 } \\
\text { A } 71.3\end{array}$ & 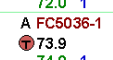 & $\begin{array}{l}76.01 \\
\text { A } 51966 \\
\text { (c } 74.99\end{array}$ \\
\hline A FC1017 & A $1196 \mathrm{~T}$ & A FC2001 & $\begin{aligned} & 3.011 \\
\text { A FC2036 } & -1\end{aligned}$ & $\begin{aligned} & 3.07 \\
& \text { A FC2063 }\end{aligned}$ & A FC3011 & A FC3065 & A FC3113 & A FC3158 & $\begin{aligned} 73.01 \\
\text { A FC4021 }\end{aligned}$ & A FC4042-1 & $\begin{array}{l}75.01 \\
\text { A FC } 4075\end{array}$ & $\begin{array}{l}72.01 \\
\text { A FC5017 }\end{array}$ & A FC5036-2 & \\
\hline (1) $717.7 \quad 1$ & $\begin{array}{ccc}(\mathbb{T} 73.3 \\
74.0 & 1\end{array}$ & (1) $\begin{array}{lll}73.0 & \\
74.0 & 1\end{array}$ & $\begin{array}{ccc}1072.6 \\
73.0\end{array}$ & (it) 72.3 & $\begin{array}{l}\text { (3) } 74.7 \\
74.01\end{array}$ & (T) 74.14 & (T) 73.901 & (1) 71.5 & (1) 74.2 & $\begin{array}{l}\text { (T) } 73.8 \mathrm{C} \\
73.0 \mathrm{C} 1\end{array}$ & (T) 72.51 & (T) $73.8 \quad 1$ & $\Theta_{74.0}^{73.3}$ & $\frac{\text { MODEL Legend }}{1-\operatorname{Coglin}}$ \\
\hline $\begin{array}{l}\text { A FC1019 } \\
\text { (1) } 72.8\end{array}$ & $\begin{array}{l}\text { A FC1C12 } \\
\text { (ब) } 74.6\end{array}$ & $\begin{array}{l}\text { A FC2004 } \\
\text { (ब) } 73.1\end{array}$ & $\begin{array}{l}\text { A FC2042 } \\
\text { (1) } 73.0\end{array}$ & $\begin{array}{l}\text { A FC2071 } \\
\text { (7) } 71.8\end{array}$ & $\begin{array}{l}\text { A FC3014 } \\
\text { () } 74.9\end{array}$ & $\begin{array}{l}\text { A FC3094C } \\
\text { if } 74.7\end{array}$ & $\begin{array}{l}\text { A FC3114X } \\
\text { (1) } 72.8\end{array}$ & $\begin{array}{l}\text { A FC3160 } \\
\text { (1) } 71.7\end{array}$ & $\begin{array}{l}\text { A FC4024-1 } \\
\text { (i) } 73.6\end{array}$ & $\begin{array}{l}\text { A FC4042-2 } \\
\text { (]) } 73.9\end{array}$ & $\begin{array}{l}\text { A FC4077 } \\
\text { (1) } 72.5\end{array}$ & $\begin{array}{l}\text { A FC5020 } \\
\text { ब } 71.5\end{array}$ & $\begin{array}{l}\text { A FC5037-1 } \\
\text { क } 72.6\end{array}$ & $\begin{array}{l}1=\text { Cooling } \\
2=\text { Heating }\end{array}$ \\
\hline $\begin{array}{l}\text { A FC1027 } \\
\text { A FC1.7 }\end{array}$ & $\begin{array}{l}\text { A FC1. } 1 \\
\text { A FC1 } \\
\text { T) } 74.1\end{array}$ & $\begin{array}{l}\text { A FC2010 } \\
\text { A FC2005 } \\
\text { (1) } 74.1\end{array}$ & $\begin{array}{rl}73.01 & 1 \\
\text { A FC2043 } \\
\text { ه } 73.4 \text { NENT }\end{array}$ & $\begin{aligned} 71.01 \\
\text { A FC2077-1 } \\
\text { T } 71.07-0\end{aligned}$ & $\begin{array}{l}\text { T4.0 } 1 \\
\text { A CC3016 } \\
\text { T } 72.3\end{array}$ & $\begin{array}{l}75.01 \\
\text { A FC3096E } \\
\text { (T) } 73.0\end{array}$ & $\begin{array}{l}73.01 \\
\text { A FC3115 } \\
\text { († } 72.3\end{array}$ & $\begin{aligned} & 72.01 \\
& \text { A F } F 3167 X \\
& \text { (A) } 72.1\end{aligned}$ & $\begin{array}{l}73.01 \\
\text { A FC4024-2 } \\
\text { (i) } 73.0\end{array}$ & $\begin{array}{l}\text { T4.0 1 } \\
\text { A FC4043-1 } \\
\text { ब } 73.1\end{array}$ & $\begin{aligned} 73.01 \\
\text { A } F 40811 \\
\text { if } 73.8\end{aligned}$ & $\begin{array}{l}72.01 \\
\text { A FC5023 } \\
\text { (T) } 74.1\end{array}$ & $\begin{array}{l}72.02 \\
\text { A F } F 0037-2 \\
\text { ه } 72.0\end{array}$ & LW1 1 Wost LVI IEart \\
\hline $\begin{array}{l}72.0 \quad 1 \\
\text { A FC1028 } \\
\text { (4) } 73.6\end{array}$ & $\begin{array}{l}70.01 \\
\text { A FC1050A } \\
\text { T } 74.9\end{array}$ & $\begin{array}{rl}74.0 & 1 \\
\text { A F F 2007 } \\
\text { A } 75.5\end{array}$ & 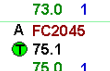 & $\begin{array}{l}\text { A FC2017-2 } \\
\text { @i( } 71.5\end{array}$ & $\begin{array}{r}72.01 \\
\text { A F F } 3019 \\
\text { ब } 73.6\end{array}$ & $\begin{array}{l}\text { A } 3.04 \mathrm{C} \\
\text { if } 74.4 \\
75.01\end{array}$ & 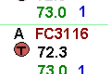 & $\begin{array}{l}\text { A } 4040 \mathrm{~A} \\
\text { (1) } 73.0\end{array}$ & $\begin{array}{l}A 4040 \\
\text { A } 73.9\end{array}$ & $\begin{array}{l}73.01 \\
\text { A FC4043-2 } \\
\text { A } 73.3\end{array}$ & $\begin{array}{l}\text { A FC40899 } \\
\text { it } 73.0\end{array}$ & $\begin{array}{l}\text { A FC50.0 } \\
\text { A F5.1 } \\
\text { (74.4 }\end{array}$ & $\begin{array}{l}\text { A FC5045-1 } \\
\text { A } 70.8\end{array}$ & 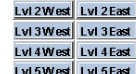 \\
\hline & & & & & & & & & & & & & & 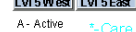 \\
\hline
\end{tabular}

Figure B-1. BMS screenshot for 1:02 p.m. 8/18/2014.

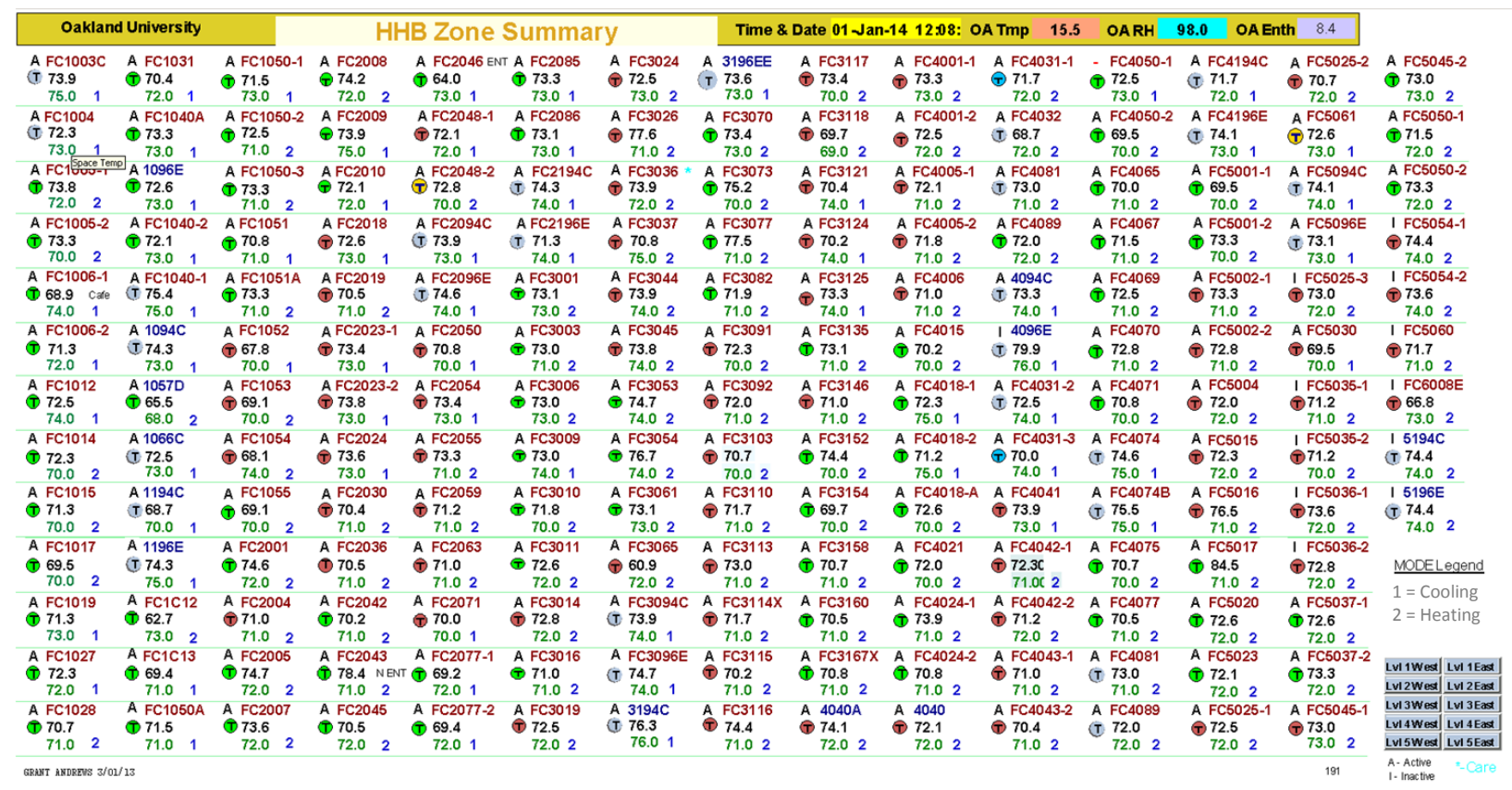

Figure B-2. BMS screenshot for 12:08 p.m. 1/1//2014. 


\begin{tabular}{|c|c|c|c|c|c|c|c|c|c|c|c|c|c|c|c|c|}
\hline \multicolumn{3}{|c|}{ Oakland University } & \multicolumn{4}{|c|}{ HHB Zone Summary } & \multicolumn{2}{|c|}{ Time \& Date 07-Feb-1 } & \multicolumn{2}{|c|}{$1407: 49:$ OA Tmp } & \multirow{2}{*}{17.9} & \multirow{2}{*}{$\begin{array}{c}\text { OARH } \\
\text { - FC4050-1 }\end{array}$} & 98.1 & OA Enth & \multirow{2}{*}{$\frac{\text { th } 8.3}{\text { I FC5025-2 }}$} & \multirow[b]{2}{*}{ A FC5045-2 } \\
\hline A FC1003C & A FC1031 & A FC1050-1 & A FC2008 & A FC2046 ENT & 1T A FC2085 & A FC3024 & A $3196 \mathrm{EE}$ & A FC3117 & A FC4001-1 & A FC403 & & & A FC4 & $24194 \mathrm{C}$ & & \\
\hline $\begin{array}{r}73.4 \\
75.0\end{array}$ & $\begin{array}{l}69.9 \\
72.0\end{array}$ & (1) 72.1 & $\begin{array}{l}74.9 \\
72.0\end{array}$ & (1) 63.4 & & (T) 72.6 & (T) 72.3 & & (T) 72.8 & (ㄷ) 71.0 & & & (1) 72. & & (T) 71.2 & (1) 73.3 \\
\hline & $\begin{array}{r}72.01 \\
\text { A FC1040A }\end{array}$ & A FC1050-2 & A FC2009 & $\begin{array}{c}73.01 \\
\text { A FC2048-1 }\end{array}$ & $\begin{array}{r}73.01 \\
\text { A FC2086 }\end{array}$ & $\begin{array}{r}73.02 \\
\text { A. FC } 3026\end{array}$ & $\begin{array}{r}73.01 \\
\text { A. FC3070 }\end{array}$ & $\begin{array}{r}70.02 \\
7\end{array}$ & 73.02 & 72.0 & 2 & $\begin{array}{ll}74.01 \\
1\end{array}$ & 72. & 2.01 & $\begin{array}{r}72.02 \\
-F C 5061\end{array}$ & $\begin{array}{r}73.02 \\
A F C 5050-1\end{array}$ \\
\hline T 72.1 & $\begin{array}{l}\text { A FC1040A } \\
\text { (1) } 72.0\end{array}$ & (T) 72.1 & จ 74.1 & A 73.3 & A 73.6 & $\begin{array}{l}\text { A FC3026 } \\
\text { (1) } 72.5\end{array}$ & $\begin{array}{l}\text { A FC3070 } \\
\text { (T) } 73.7\end{array}$ & $\begin{array}{l}\text { A FC3118 } \\
\text { (1) } 67.6\end{array}$ & $\begin{array}{l}\text { A FCA4001-2 } \\
\text { (T) } 71.7\end{array}$ & $\begin{array}{l}\text { I FC403 } \\
\text { I } 69.7\end{array}$ & & $\begin{array}{l}\text { A FC } 4050-2 \\
\text { (T) } 69.7\end{array}$ & $\begin{array}{l}\text { A } \mathrm{FC} 4 \\
\text { (T) } 73 .\end{array}$ & 3.4 & $\begin{array}{l}\text { A FC5061 } \\
\text { (i) } 74.3\end{array}$ & $\begin{array}{l}\text { A FC5050-1 } \\
\text { (1) } 71.5\end{array}$ \\
\hline $\begin{array}{ll}73.0 \quad 1 \\
\end{array}$ & $\begin{array}{lll}73.0 & 1\end{array}$ & $\begin{array}{ll}71.0 & 2\end{array}$ & $75.0 \quad 1$ & 72.01 & 73.01 & 73.01 & 73.02 & 69.02 & 72.02 & 72.0 & & 72.02 & & 3.01 & 73.01 & 72.02 \\
\hline $\begin{array}{l}\text { A FC1005-1 } \\
\text { (T) } 70.8\end{array}$ & $\begin{array}{l}\text { A } 1096 \mathrm{E} \\
\text { (T) } 72.0\end{array}$ & $\begin{array}{l}\text { A FC1050.3 } \\
\text { (T) } 73.1\end{array}$ & $\begin{array}{l}\text { A FC2010 } \\
772.5\end{array}$ & $\begin{array}{l}\text { A } \mathrm{FC} 2048-2 \\
\text { () } 71.2\end{array}$ & $\begin{array}{l}\text { A FC2194C } \\
\text { I } 74.9\end{array}$ & $\begin{array}{l}\text { A FC3036 * } \\
\text { (1) } 72.1\end{array}$ & $\begin{array}{l}\text { A FC3073 } \\
\text { (1) } 76.8\end{array}$ & $\begin{array}{l}\text { A FC3121 } \\
\text { (D) } 73.1\end{array}$ & $\begin{array}{l}\text { A FC4005-1 } \\
\text { () } 71.3\end{array}$ & $\begin{array}{l}\text { A FC408 } \\
\text { I } 74.4\end{array}$ & & $\begin{array}{l}\text { A FC4065 } \\
\text { (T) } 71.2\end{array}$ & $\begin{array}{l}\text { A FC5 } \\
\text { (i) } 69 .\end{array}$ & $50001-1$ & $\begin{array}{l}\text { A FC5094C } \\
\text { T } 74.6\end{array}$ & $\begin{array}{l}\text { A FC5050-2 } \\
\text { (T) } 72.3\end{array}$ \\
\hline $\begin{array}{l}74.0 \\
74.0\end{array}$ & $\begin{array}{ll}71.0 \quad 2\end{array}$ & $\begin{array}{ll}73.0 & 1\end{array}$ & $\begin{array}{ll}72.0 & 1\end{array}$ & 70.02 & 74.01 & 74.01 & 70.02 & 74.01 & 71.02 & 71.0 & & 71.02 & 70. & 0.02 & $74.0 \quad 1$ & 72.02 \\
\hline $\begin{array}{l}\text { A FC } 1005-2 \\
\text { (T) } 70.7 \\
72.0\end{array}$ & $\begin{array}{l}\text { A FC1040-2 } \\
\text { (T) } 71.8\end{array}$ & $\begin{array}{l}\text { A FC1051 } \\
\text { (T) } 71.5\end{array}$ & $\begin{array}{l}\text { A FC2018 } \\
\text { T) } 73.4\end{array}$ & $\begin{array}{l}\text { A FC2094C } \\
\text { ( } 73.9\end{array}$ & $\begin{array}{l}\text { A FC2196E } \\
\text { T } 72.6\end{array}$ & $\begin{array}{l}\text { A FC3037 } \\
\text { (T) } 69.5\end{array}$ & $\begin{array}{l}\text { A FC3077 } \\
\text { (T) } 76.2\end{array}$ & $\begin{array}{l}\text { A FC3124 } \\
\text { (c) } 72.1\end{array}$ & $\begin{array}{l}\text { A FC4005-2 } \\
\text { (T) } 71.5\end{array}$ & $\begin{array}{l}\text { A FC408 } \\
\text { (1) } 71.7 \\
720\end{array}$ & & $\begin{array}{l}\text { A FC4067 } \\
\text { T) } 70.4\end{array}$ & $\begin{array}{l}\text { A FC5 } \\
\text { T) } 72 . \\
70\end{array}$ & & $\begin{array}{l}\text { A FC5096E } \\
\text { I } 74.1\end{array}$ & $\begin{array}{l}\text { A FC5054-1 } \\
\text { T) } 74.6\end{array}$ \\
\hline $\begin{array}{l}72.0 \quad 1 \\
\text { A FC1006-1 }\end{array}$ & $\begin{array}{c}71.0 \quad 2 \\
\text { A FC1040-1 }\end{array}$ & $\begin{array}{r}71.0 \quad 1 \\
7101051 A\end{array}$ & $\begin{array}{l}73.0 \quad 1 \\
7.02019\end{array}$ & & 74.01 & $\begin{array}{r}75.02 \\
A . F C 3044\end{array}$ & $\begin{array}{r}71.02 \\
7.3082\end{array}$ & $\begin{array}{r}74.01 \\
\end{array}$ & $\begin{array}{l}71.02 \\
7.19406\end{array}$ & 72.0 & & $\begin{array}{r}71.02 \\
7.4069\end{array}$ & & & 73.01 & 52 \\
\hline $\begin{array}{l}\text { A FC1006-1 } \\
\text { (T) } 68.3 \text { Cafe }\end{array}$ & $\begin{array}{l}\text { A FC1040-1 } \\
\text { T } 75.7\end{array}$ & $\begin{array}{l}\text { A FC1051A } \\
\text { () } 73.3\end{array}$ & $\begin{array}{l}\text { A FC2019 } \\
\text { (T) } 68.7\end{array}$ & $\begin{array}{l}\text { A FC2096E } \\
\text { (I) } 73.0\end{array}$ & $\begin{array}{l}\text { A FC3001 } \\
\text { (i) } 74.7\end{array}$ & $\begin{array}{l}\text { A } \text { FC3044 } \\
\text { (T) } 77.6\end{array}$ & $\begin{array}{l}\text { A FC3082 } \\
\text { (T) } 70.7\end{array}$ & $\begin{array}{l}\text { A FC3125 } \\
\text { (1) } 73.9\end{array}$ & $\begin{array}{l}\text { A } F C 4006 \\
\text { (T) } 71.2\end{array}$ & $\begin{array}{l}\text { A } 4094 \mathrm{C} \\
\text { (I } 73.1\end{array}$ & & $\begin{array}{l}\text { A FC4069 } \\
\text { (1) } 72.6\end{array}$ & $\begin{array}{l}1 \mathrm{FC5} \\
\text { (c) } 71 .\end{array}$ & $\begin{array}{c}25002- \\
1.7\end{array}$ & $\begin{array}{l}\text { A FC5025-3 } \\
\text { (T) } 71.8\end{array}$ & $\begin{array}{l}\text { A FC5054-2 } \\
\text { (T) } 74.1\end{array}$ \\
\hline $74.0 \quad 1$ & $\begin{array}{lll}75.0 & 1\end{array}$ & $\begin{array}{l}71.0 \quad 2 \\
\end{array}$ & $\begin{array}{l}71.0 \quad 2 \\
\end{array}$ & 74.01 & 75.02 & 78.02 & 71.02 & 74.01 & 73.01 & 74.0 & & 71.02 & 71. & 1.02 & 74.01 & 74.02 \\
\hline A FC1006-2 & A $1094 \mathrm{C}$ & A FC1052 & A FC2023-1 & A FC2050 & A FC3003 & A FC3045 & A FC3091 & A FC3135 & A FC4015 & I $4096 \mathrm{E}$ & & A $F C 4070$ & $1 \mathrm{FCS}$ & $5002-2$ & A FC5030 & A FC5060 \\
\hline (1) $\begin{array}{l}70.7 \\
72.0 \quad 1\end{array}$ & $\begin{array}{r}\top_{72.1} \\
73.0\end{array}$ & $\begin{array}{ll}7 & 70.5 \\
68.0 \quad 2\end{array}$ & $\begin{array}{r}73.4 \\
73.0\end{array}$ & (1) 69.5 & (c) 72. & (T) $\begin{aligned} 73.4 \\
74.0 \quad 2\end{aligned}$ & $\begin{array}{l}70.2 \\
70.02\end{array}$ & (T) 75.12 & (i) $\begin{array}{ll}67.8 \\
71.0 \quad 1\end{array}$ & ( $\begin{array}{r}78.6 \\
76.0\end{array}$ & & (1) $\begin{array}{ll}73.3 \\
71.02\end{array}$ & (1) 71. & 1.32 & (T) 70.4 & $\begin{array}{l}\text { (1) } 71.3 \\
71.02\end{array}$ \\
\hline $\begin{array}{l}\text { A FC1012 } \\
\text { T) } 72.6 \\
74.0 \quad 1\end{array}$ & $\begin{array}{l}\text { A } 1057 \mathrm{D} \\
\text { T) } 64.5 \\
68.0 \quad 2\end{array}$ & $\begin{array}{l}\text { A FC1053 } \\
\text { (T) } 70.2 \quad \\
70.0 \quad 2\end{array}$ & $\begin{array}{l}\text { A FC2023-2 } \\
\text { (ब 73.8 } \\
73.0 \quad 1\end{array}$ & $\begin{array}{l}\text { A FC2054 } \\
\text { P } 73.3 \\
73.0 \quad 1\end{array}$ & $\begin{array}{l}\text { A FC3006 } \\
\text { A } 74.1 \\
73.02\end{array}$ & $\begin{array}{l}\text { A FC3053 } \\
\text { C) } 74.1 \\
74.02\end{array}$ & $\begin{array}{l}\text { A FC3092 } \\
\text { (T) } 69.1 \\
71.02\end{array}$ & $\begin{array}{l}\text { A FC3146 } \\
\text { C) } 67.002 \\
71.02\end{array}$ & $\begin{array}{l}\text { A FC4018-1 } \\
\text { (T) } 73.8 \\
73.02\end{array}$ & $\begin{array}{l}\text { A FCA03 } \\
\text { I } 74.7 \\
74.0\end{array}$ & & $\begin{array}{l}\text { A FC4071 } \\
\text { (T) } 72.5 \\
70.022\end{array}$ & $\begin{array}{l}1 \mathrm{FC5} \\
\text { (T) } 71 . \\
72 .\end{array}$ & 1.7 & $\begin{array}{l}\text { A FC5035-1 } \\
\text { C } 73.3 \quad 2 \\
71.02\end{array}$ & $\begin{array}{l}\text { A FC6008E } \\
\text { T) } 69.4 \\
73.02\end{array}$ \\
\hline A FC1014 & A $1066 \mathrm{C}$ & A FC1054 & A FC2024 & A FC2055 & A FC3009 & A FC3054 & A FC3103 & A FC3152 & A FC4018-2 & A $\mathrm{FC}_{403}$ & 0313 & A FC4074 & & & A FC5035-2 & $\begin{array}{l}\text { A } 5194 \mathrm{C} \\
\text {. } 746\end{array}$ \\
\hline (1) $\begin{array}{ll}71.0 \\
70.0\end{array}$ & $\begin{array}{r}\top 73.0 \\
73.0\end{array}$ & 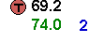 & (1) $\begin{aligned} 73.0 \\
73.0\end{aligned}$ & $\begin{array}{l}72.3 \\
71.022\end{array}$ & (1) 76.8 & (1) $\begin{array}{l}73.6 \\
74.0 \quad 2\end{array}$ & (T) 70.5 & $\begin{array}{l}73.0 \\
73.0 \quad 2\end{array}$ & (1) $\begin{array}{l}71.7 \\
73.0 \quad 2\end{array}$ & (T) 69.2 & & (T $\begin{array}{l}71.7 \\
75.0\end{array}$ & (1) 71 . & & $\begin{array}{l}73.4 \\
70.0 \quad 2\end{array}$ & $\begin{aligned} &(T 74.6 \\
& 74.0 \quad 2\end{aligned}$ \\
\hline A FC1015 & A $1194 C$ & A FC1055 & A FC2030 & A FC2059 & A FC3010 & A FC3061 & A FC3110 & A FC3154 & A FC4018-A & A A FC40 & 041 & A FC4074B & $1 \mathrm{FCS}$ & 55016 & A FC5036-1 & A 5196E \\
\hline & $\circlearrowleft 72.3$ & (T) 68.1 & (T) 71.5 & (1) 71.2 & (T) 73.6 & (T) 71.3 & (T) 72.0 & (I) 72.0 & (T) 70.4 & (T) 72.1 & & (1) 73.3 & & & & \\
\hline $70.0 \quad 2$ & $\begin{array}{ll}72.0 & 1\end{array}$ & $70.0 \quad 2$ & $\begin{array}{l}71.0 \quad 2 \\
\end{array}$ & 71.02 & 72.02 & 74.02 & 71.02 & 73.02 & 71.01 & 73.0 & & 75.01 & & & 72.02 & 74.02 \\
\hline A FC1017 & A 1196E & A FC2001 & A FC2036 & A FC2063 & A FC3011 & A FC3065 & A FC3113 & A FC3158 & A FC4021 & A FC404 & $042-1$ & A FC4075 & A FCE & 25017 & A FC6036-2 & \\
\hline (1) $\begin{array}{ll}69.2 \\
70.0\end{array}$ & $\begin{array}{r}\top 75.2 \\
75.0\end{array}$ & (1) 72.6 & (1) 71.3 & (1) 71.0 & (1) 71.0 & (1) 65.4 & (1) 72.6 & & (D) 71.2 & (1) $71.3 \mathrm{C}$ & & (1) 72.3 & & & (T) 73 & MODELegend \\
\hline $\begin{array}{r}70.0 \quad 2 \\
4.91019\end{array}$ & $\begin{array}{r}75.0 \quad 1 \\
4.012\end{array}$ & $\begin{array}{r}72.0 \quad 2 \\
530\end{array}$ & $\begin{array}{l}71.0 \quad 2 \\
502\end{array}$ & $\begin{array}{r}71.02 \\
\end{array}$ & 72.02 & $\begin{array}{l}74.01 \\
\end{array}$ & 71.02 & $\begin{array}{l}71.02 \\
\end{array}$ & 72.02 & 73.00 & & $\begin{array}{l}70.0 \quad 2 \\
0.7\end{array}$ & 73. & 3.01 & $72.0 \quad 2$ & 1 = Cooling \\
\hline $\begin{array}{l}\text { A FC1019 } \\
\text { (1) } 71.8\end{array}$ & $\begin{array}{l}\text { A FC1C12 } \\
\text { (1) } 59.7\end{array}$ & $\begin{array}{l}\text { A FC2004 } \\
\text { (T) } 70.7\end{array}$ & $\begin{array}{l}\text { A FC2042 } \\
\text { (1) } 67.9\end{array}$ & $\begin{array}{l}\text { A FC2071 } \\
\text { (T) } 70.7\end{array}$ & $\begin{array}{l}\text { A FC3014 } \\
\text { (1) } 74.6\end{array}$ & $\begin{array}{l}\text { A FC } 3094 \mathrm{C} \\
\text { (I) } 76.6\end{array}$ & $\begin{array}{l}\text { A FC3114X } \\
\text { (c) } 70.5\end{array}$ & $\begin{array}{l}\text { A FC3160 } \\
\text { (T) } 71.0\end{array}$ & $\begin{array}{l}\text { A FC4024-1 } \\
\text { (1) } 73.4\end{array}$ & $\begin{array}{l}\text { A FC40. } \\
\text { (1) } 70.5\end{array}$ & & $\begin{array}{l}\text { A FC4077 } \\
\text { (1) } 71.2\end{array}$ & $\begin{array}{l}\text { A FC5 } \\
\text { (1) } 66 .\end{array}$ & 5.5020 & $\begin{array}{l}\text { A FC5037-1 } \\
\text { (T) } 72.6\end{array}$ & $2=$ Heating \\
\hline $\begin{array}{ll}73.0 & 1\end{array}$ & $\begin{array}{ll}73.0 \quad 2 & 2\end{array}$ & $\begin{array}{ll}71.0 \quad 2 \\
\end{array}$ & $\begin{array}{ll}71.0 \quad 2 \\
\end{array}$ & 70.01 & 74.01 & 76.01 & 71.02 & 75.02 & 71.02 & 74.0 & & 71.02 & 72. & 2.01 & $72.0 \quad 2$ & \\
\hline $\begin{array}{l}\text { A FC1027 } \\
\text { (1) } 71.8\end{array}$ & $\begin{array}{l}\text { A FC1C13 } \\
\text { (1) } 70.7\end{array}$ & $\begin{array}{l}\text { I FC2005 } \\
\text { (1) } 71.0\end{array}$ & $\begin{array}{l}\text { A FC2043 } \\
\text { (T) } 77.1 \text { N ENT }\end{array}$ & $\begin{array}{l}\text { A FC2077-1 } \\
\text { (T) } 69.7\end{array}$ & $\begin{array}{l}\text { A FC3016 } \\
\text { (T) } 71.3\end{array}$ & $\begin{array}{l}\text { A FC3096E } \\
\text { (T } 72.8\end{array}$ & $\begin{array}{l}\text { A FC3115 } \\
\text { (1) } 71.5\end{array}$ & $\begin{array}{l}\text { A FC3167X } \\
\text { (T) } 71.7\end{array}$ & $\begin{array}{l}\text { A FC4024-2 } \\
\text { (1) } 70.5\end{array}$ & $\begin{array}{l}2 \text { A FC40 } \\
\text { (ब) } 73.1\end{array}$ & & $\begin{array}{l}\text { A FC4081 } \\
\text { (T } 74.4\end{array}$ & $\begin{array}{l}\text { A FCS } \\
\text { (i) } 71 \text {. }\end{array}$ & 55023 & $\begin{array}{l}\text { A FC5037-2 } \\
\text { (T) } 73.3\end{array}$ & LVVI 1West LVI IEast \\
\hline $\begin{array}{ll}72.0 & 1\end{array}$ & $68.0 \quad 2$ & $\begin{array}{ll}72.0 \quad 2 \\
\end{array}$ & $71.0 \quad 2$ & 72.01 & 71.02 & 74.01 & 71.02 & $\begin{array}{ll}71.0 & 2\end{array}$ & 71.02 & 71.0 & & $\begin{array}{lll}71.0 \quad 2 & 2\end{array}$ & & & 72.02 & Lv12West Lvi 2Eat \\
\hline A FC1028 & A FC1050A & A FC2007 & A FC2045 & A FC2077-2 & A FC3019 & A 319 & A $\mathrm{FC} 3116$ & A $4040 \mathrm{~A}$ & A 4040 & A FC40 & 043-2 & A FC4089 & I FC5 & c5025-1 & 045-1 & Lv13West LVI 3East \\
\hline (T) 70.4 & (T) 70.7 & (T) 73.6 & (T) 66.6 & (1) 72.0 & 73.8 & (I) 76.8 & (ิ) 75.4 & (T) 73.8 & (ד) 71.5 & (1) 72.6 & & (1) 71.7 & (ד) 71 . & & (ד) 73 & LV14 West LVI 4East \\
\hline $\begin{array}{l}71.0 \quad 2 \\
\end{array}$ & $\begin{array}{ll}71.0 & 1\end{array}$ & $\begin{array}{l}74.02 \\
2\end{array}$ & $\begin{array}{ll}72.0 & 2\end{array}$ & 72.01 & 74.01 & 76.01 & 71.02 & 72.02 & 72.02 & 71.0 & 2 & 72.02 & 72 & 2.02 & 73.02 & Lv15West Lv1 5East \\
\hline
\end{tabular}

Figure B-3. BMS screenshot for 7:49 a.m. 2/7/2014.

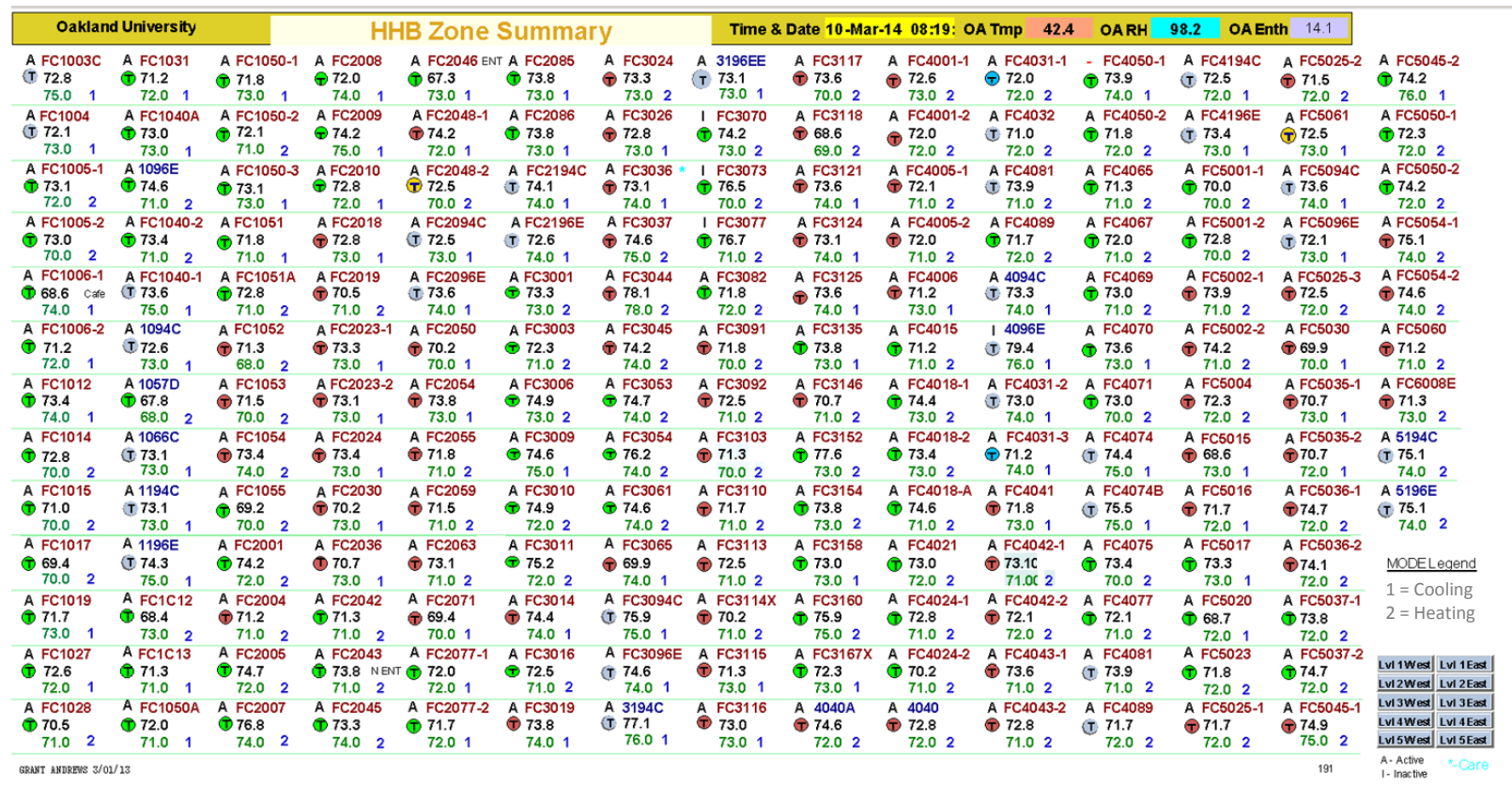

Figure B-4. BMS screenshot for 8:19 a.m. 3/10/2014. 


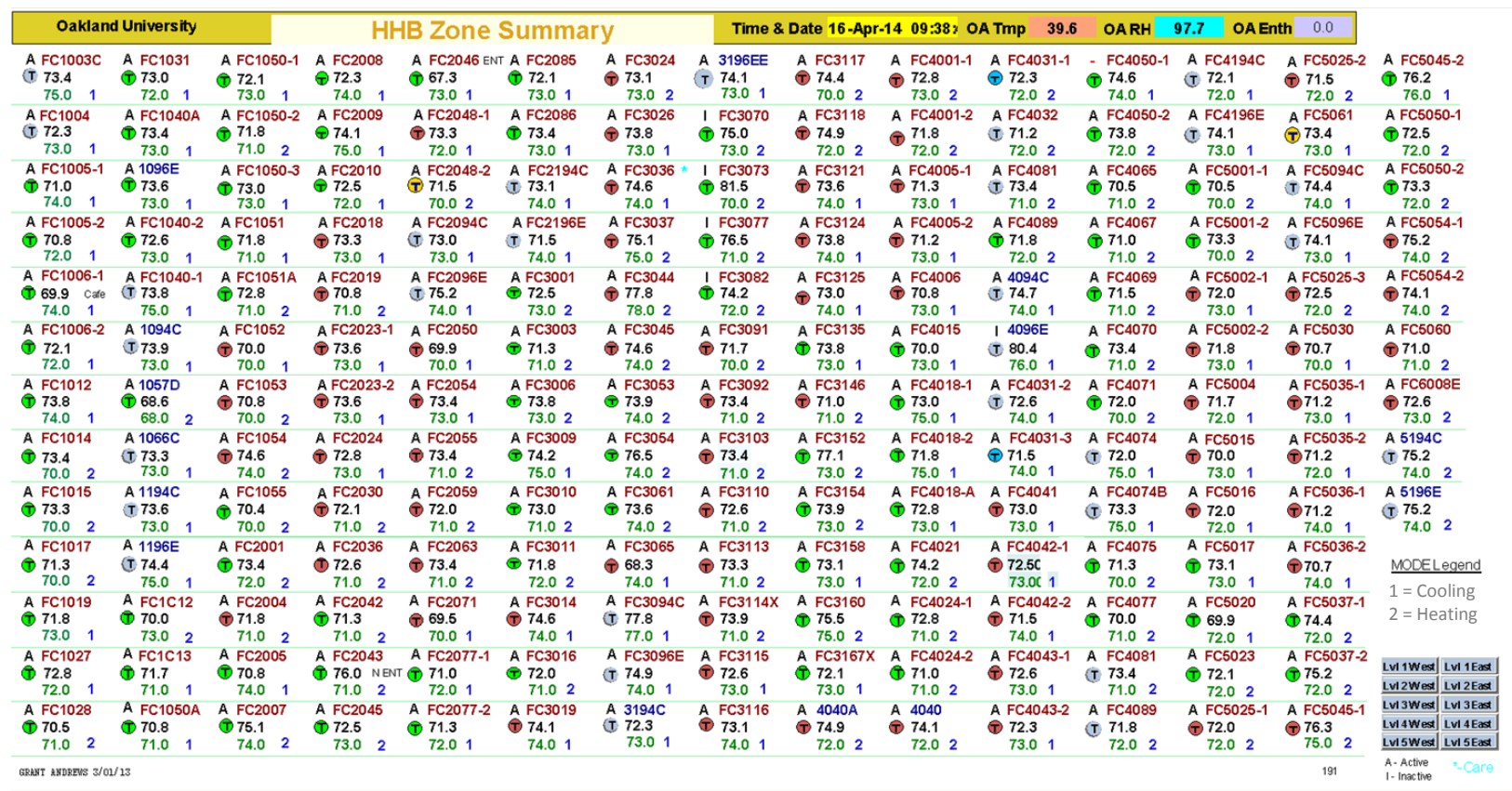

Figure B-5. BMS screenshot for 9:38 a.m. 4/16/2014.

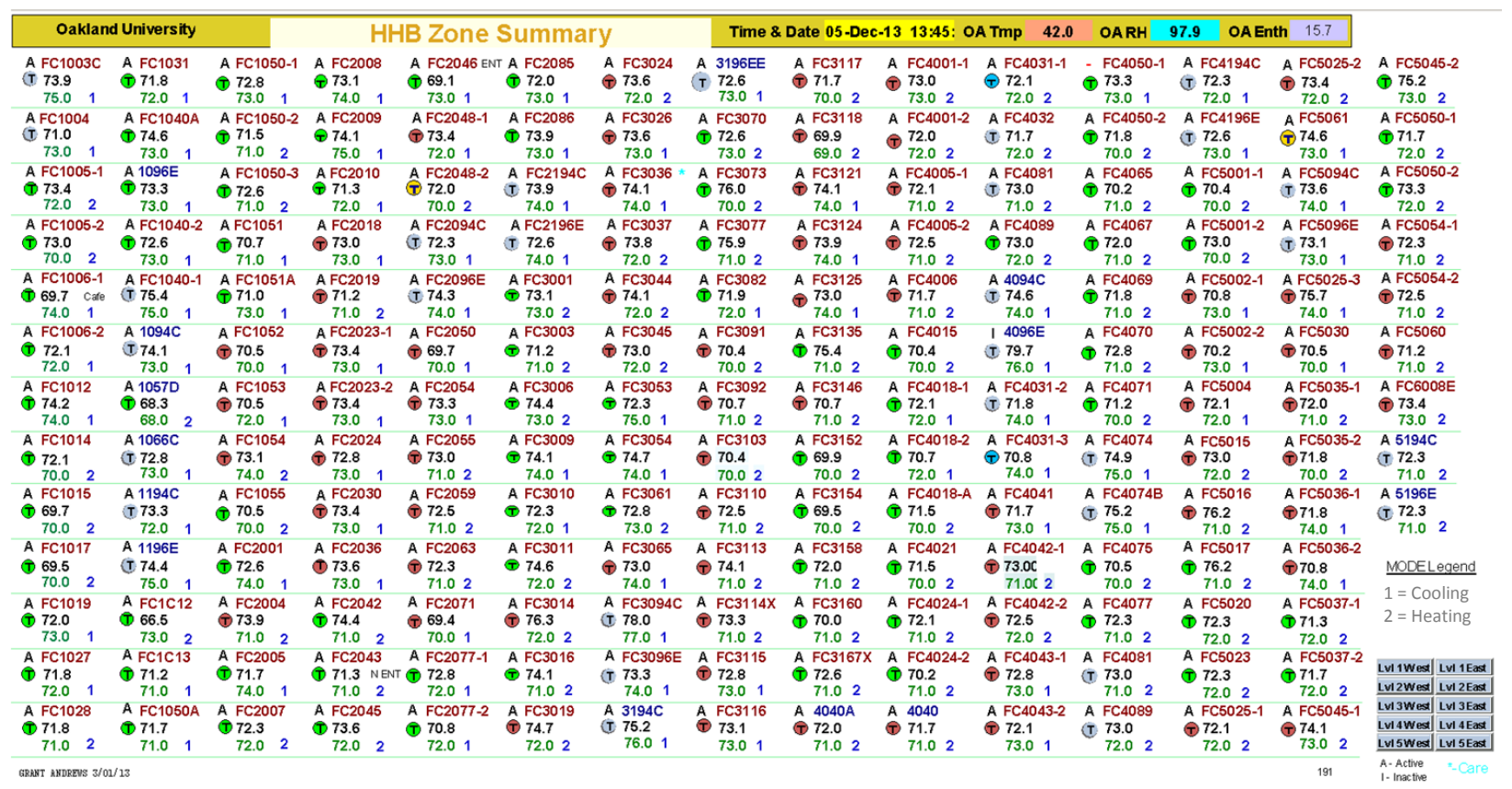

Figure B-6. BMS screenshot for 1:45 p.m. 12/9/2013. 



\section{APPENDIX C. SIMULATION RESULTS FOR THE GS-VRF SYSTEM AND BASELINE SYSTEMS}

\section{VRF System}

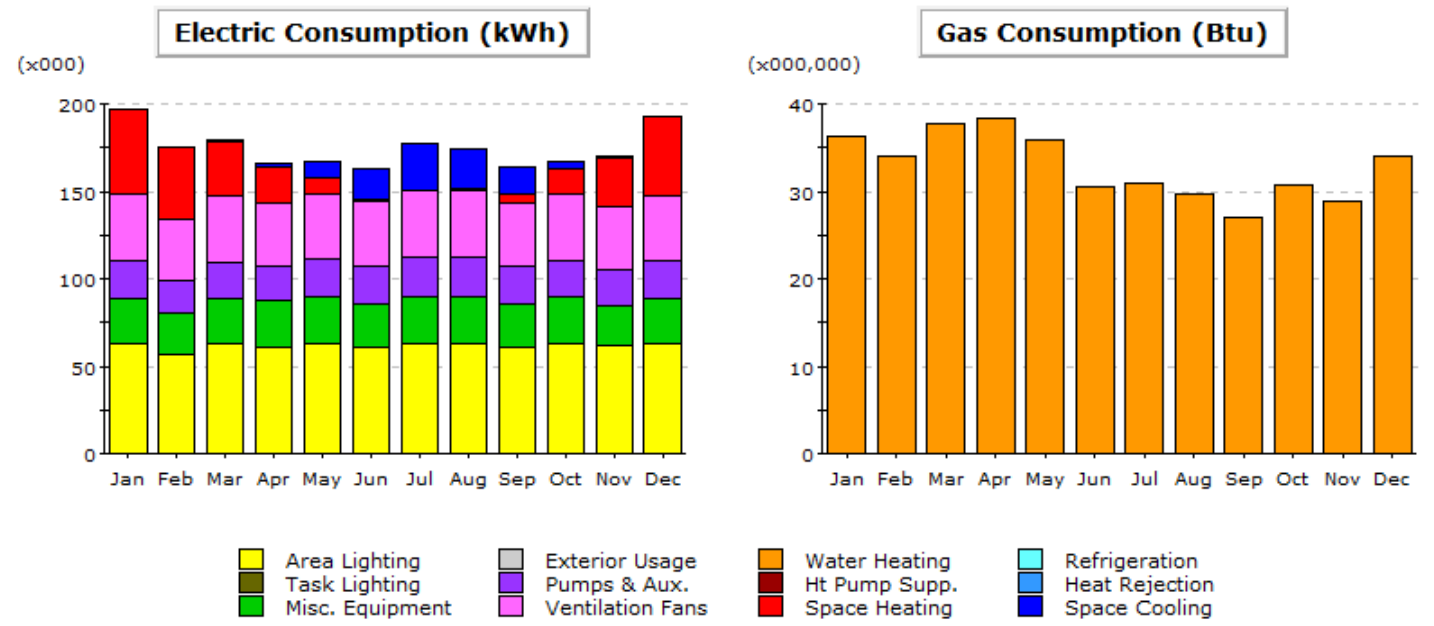

Electric Consumption ( $k$ Wh x000)

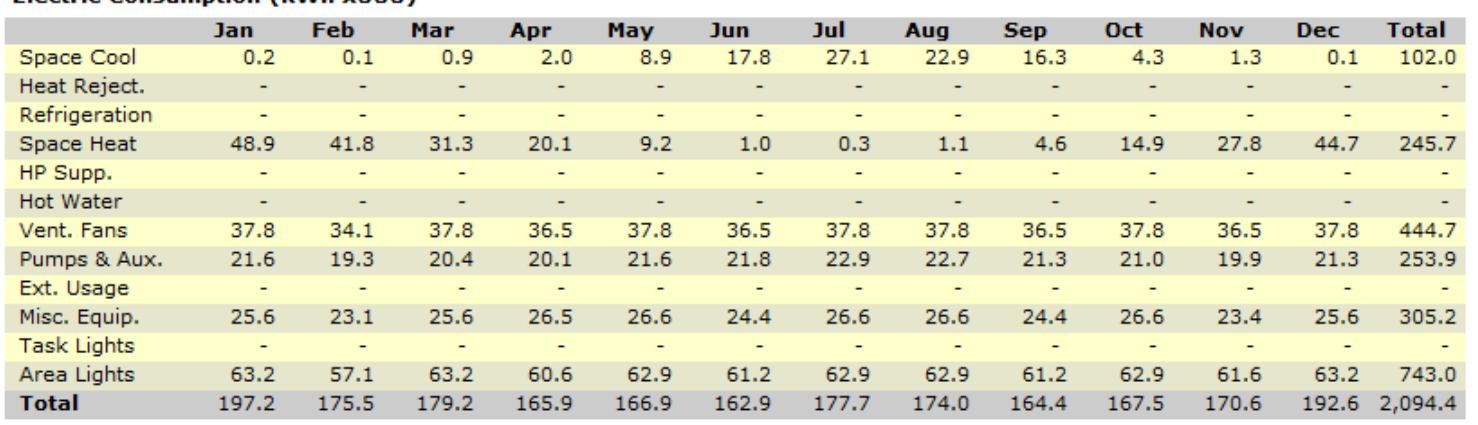

Gas Consumption (Btu x000,000)

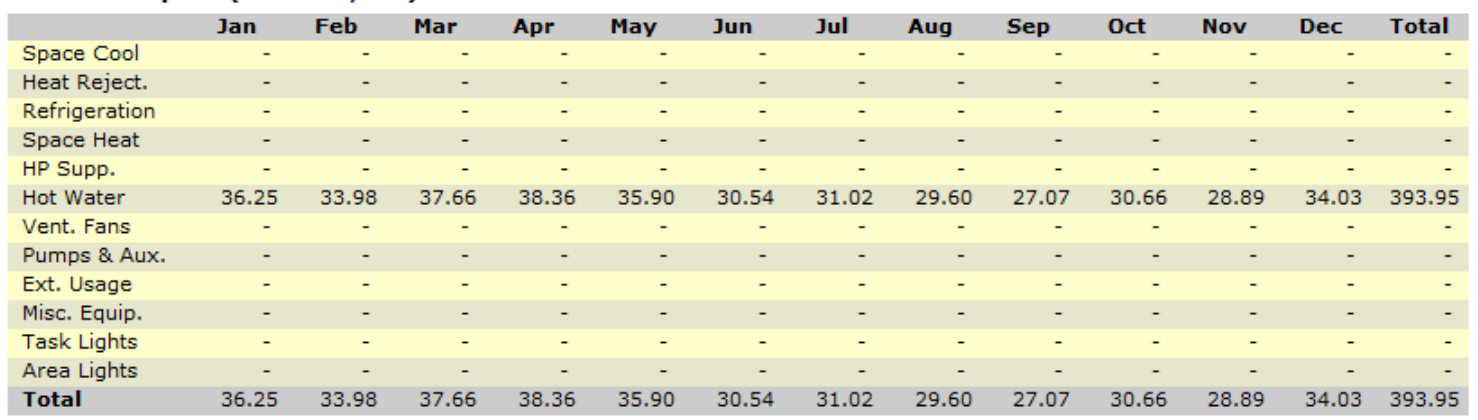




\section{Air-Cooled VAV System (Code Compliant)}

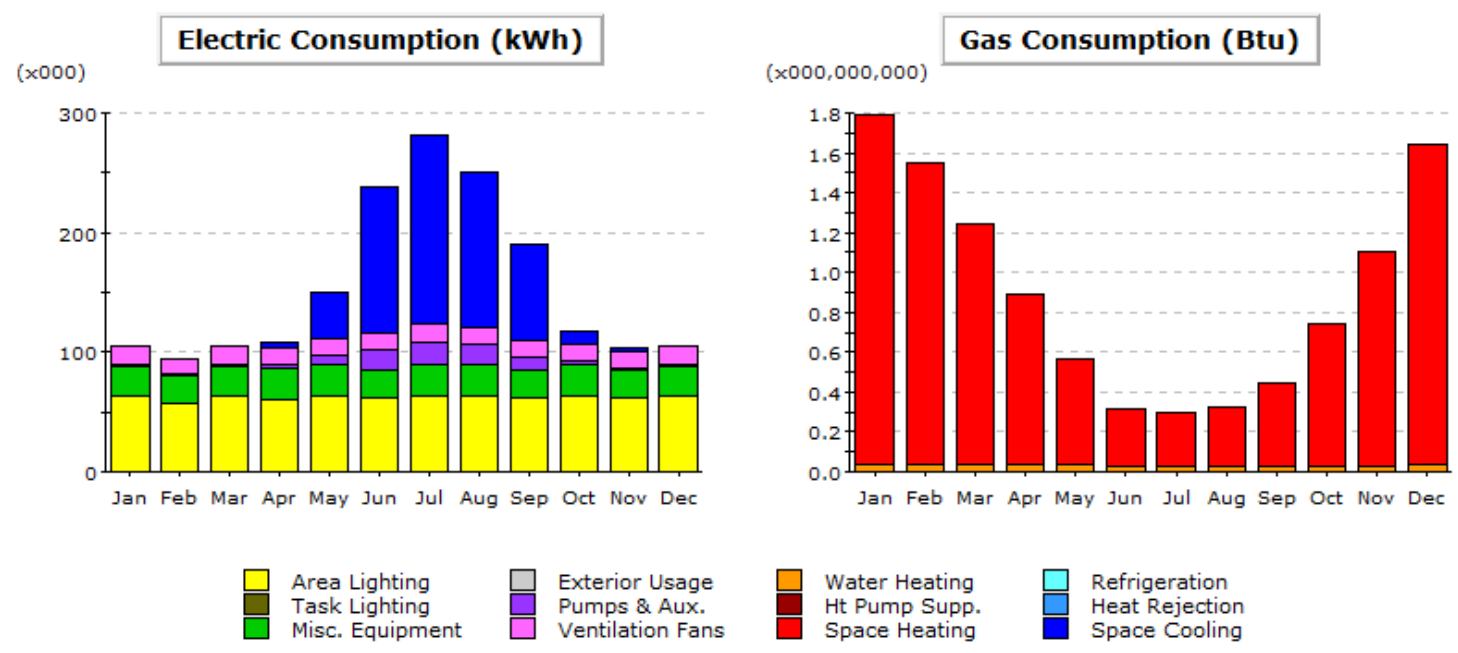

Electric Consumption (kWh x000)

\begin{tabular}{|c|c|c|c|c|c|c|c|c|c|c|c|c|c|}
\hline & Jan & Feb & Mar & Apr & May & Jun & Jul & Aug & Sep & Oct & Nov & Dec & Total \\
\hline Space Cool & - & - & 1.4 & 5.1 & 39.2 & 122.3 & 158.3 & 130.3 & 79.3 & 10.0 & 3.3 & - & 549.3 \\
\hline Heat Reject. & - & - & - & - & - & - & - & - & - & - & - & - & - \\
\hline Refrigeration & - & - & - & - & - & - & - & - & - & - & - & - & - \\
\hline Space Heat & - & - & - & - & - & - & - & - & - & - & - & - & - \\
\hline HP Supp. & - & - & - & - & - & - & - & - & - & - & - & - & - \\
\hline Hot Water & - & - & - & - & - & - & - & - & - & - & - & - & - \\
\hline Vent. Fans & 15.2 & 13.5 & 13.9 & 13.4 & 14.1 & 13.9 & 14.7 & 14.4 & 13.9 & 14.2 & 13.5 & 14.2 & 169.0 \\
\hline Pumps \& Aux. & 1.4 & 1.3 & 1.7 & 2.4 & 7.1 & 16.1 & 18.7 & 16.8 & 10.9 & 3.3 & 1.9 & 1.4 & 83.1 \\
\hline Ext. Usage & - & - & - & - & - & - & - & - & - & - & - & - & - \\
\hline Misc. Equip. & 25.6 & 23.1 & 25.6 & 26.5 & 26.6 & 24.4 & 26.6 & 26.6 & 24.4 & 26.6 & 23.4 & 25.6 & 305.2 \\
\hline Task Lights & - & - & - & - & - & - & - & - & - & - & - & - & - \\
\hline Area Lights & 63.2 & 57.1 & 63.2 & 60.6 & 62.9 & 61.2 & 62.9 & 62.9 & 61.2 & 62.9 & 61.6 & 63.2 & 743.0 \\
\hline Total & 105.4 & 95.0 & 105.8 & 108.0 & 150.0 & 238.0 & 281.3 & 251.1 & 189.7 & 117.0 & 103.8 & 104.4 & $1,849.5$ \\
\hline
\end{tabular}

Gas Consumption (Btu x000,000,000)

\begin{tabular}{|c|c|c|c|c|c|c|c|c|c|c|c|c|c|}
\hline & Jan & Feb & Mar & Apr & May & Jun & Jul & Aug & Sep & Oct & Nov & Dec & Total \\
\hline Space Cool & - & - & - & - & - & - & - & - & - & - & - & - & - \\
\hline Heat Reject. & - & - & - & - & - & - & - & - & - & - & - & - & - \\
\hline Refrigeration & - & - & - & - & - & - & - & - & - & - & - & - & - \\
\hline Space Heat & 1.75 & 1.51 & 1.21 & 0.85 & 0.53 & 0.29 & 0.26 & 0.30 & 0.42 & 0.71 & 1.08 & 1.61 & 10.50 \\
\hline HP Supp. & - & - & - & - & - & - & - & - & - & - & - & - & - \\
\hline Hot Water & 0.04 & 0.03 & 0.04 & 0.04 & 0.04 & 0.03 & 0.03 & 0.03 & 0.03 & 0.03 & 0.03 & 0.03 & 0.39 \\
\hline Vent. Fans & - & - & - & - & - & - & - & - & - & - & - & - & - \\
\hline Pumps \& Aux. & - & - & - & - & - & - & - & - & - & - & - & - & - \\
\hline Ext. Usage & - & - & - & - & - & - & - & - & - & - & - & - & - \\
\hline Misc. Equip. & - & - & - & - & - & - & - & - & - & - & - & - & - \\
\hline Task Lights & - & - & - & - & - & - & - & - & - & - & - & - & - \\
\hline Area Lights & - & - & - & - & - & - & - & - & - & - & - & - & - \\
\hline Total & 1.79 & 1.54 & 1.24 & 0.89 & 0.56 & 0.32 & 0.29 & 0.33 & 0.44 & 0.74 & 1.11 & 1.64 & 10.90 \\
\hline
\end{tabular}




\section{Air-Cooled VAV System (Best Available)}

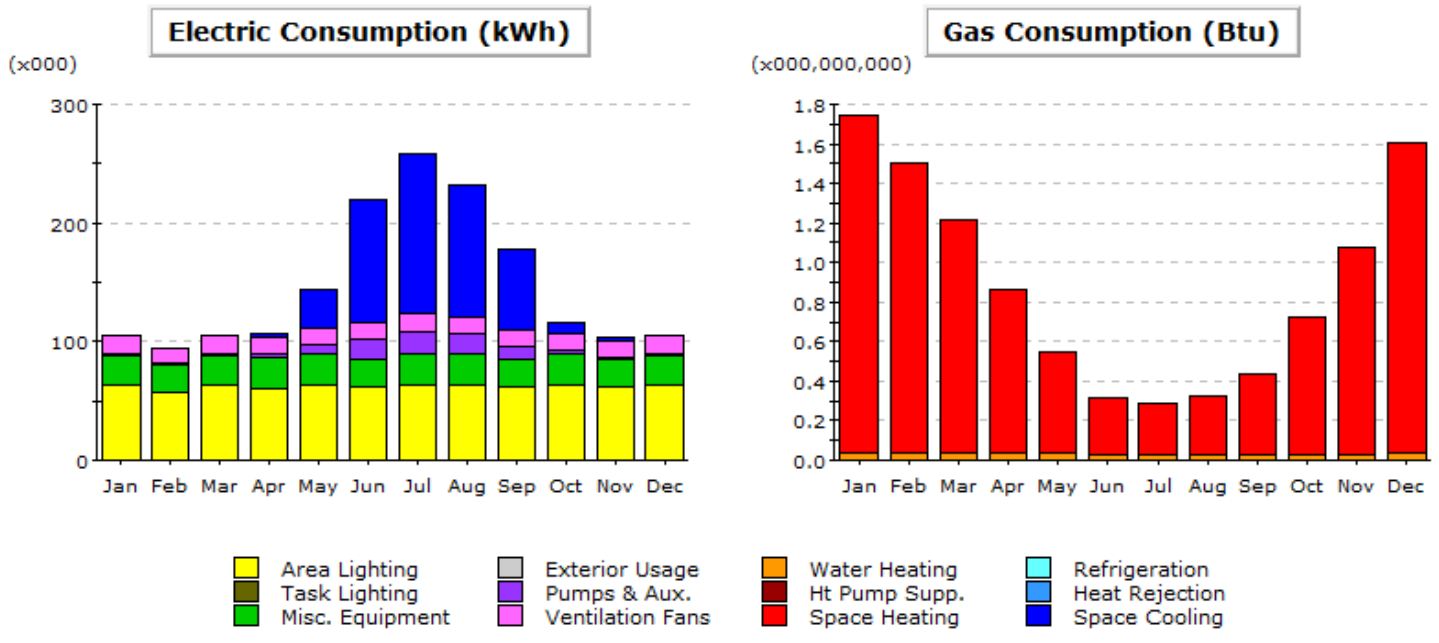

Electric Consumption ( $k$ Wh x000)

\begin{tabular}{|c|c|c|c|c|c|c|c|c|c|c|c|c|c|}
\hline & Jan & Feb & Mar & Apr & May & Jun & Jul & Aug & Sep & Oct & Nov & Dec & Total \\
\hline Space Cool & - & - & 1.2 & 4.3 & 33.5 & 104.4 & 135.2 & 111.3 & 67.7 & 8.6 & 2.9 & - & 468.9 \\
\hline Heat Reject. & - & - & - & - & - & - & - & - & - & - & - & - & - \\
\hline Refrigeration & - & - & - & - & - & - & - & - & - & - & - & - & - \\
\hline Space Heat & - & - & - & - & - & - & - & - & - & - & - & - & - \\
\hline HP Supp. & - & - & - & - & - & - & - & - & - & - & - & - & - \\
\hline Hot Water & - & - & - & - & - & - & - & - & - & - & - & - & - \\
\hline Vent. Fans & 15.2 & 13.5 & 13.9 & 13.4 & 14.1 & 13.9 & 14.7 & 14.4 & 13.9 & 14.2 & 13.5 & 14.2 & 169.0 \\
\hline Pumps \& Aux. & 1.4 & 1.3 & 1.7 & 2.4 & 7.1 & 16.1 & 18.7 & 16.8 & 10.9 & 3.3 & 1.9 & 1.4 & 83.1 \\
\hline Ext. Usage & - & - & - & - & - & - & - & - & - & - & - & - & - \\
\hline Misc. Equip. & 25.6 & 23.1 & 25.6 & 26.5 & 26.6 & 24.4 & 26.6 & 26.6 & 24.4 & 26.6 & 23.4 & 25.6 & 305.2 \\
\hline Task Lights & - & - & - & - & - & - & - & - & - & - & - & - & - \\
\hline Area Lights & 63.2 & 57.1 & 63.2 & 60.6 & 62.9 & 61.2 & 62.9 & 62.9 & 61.2 & 62.9 & 61.6 & 63.2 & 743.0 \\
\hline Total & 105.4 & 95.0 & 105.6 & 107.2 & 144.2 & 220.1 & 258.1 & 232.0 & 178.1 & 115.6 & 103.3 & 104.4 & $1,769.1$ \\
\hline
\end{tabular}

Gas Consumption (Btu x000,000,000)

\begin{tabular}{|c|c|c|c|c|c|c|c|c|c|c|c|c|c|}
\hline & Jan & Feb & Mar & Apr & May & Jun & Jul & Aug & Sep & Oct & Nov & Dec & Total \\
\hline Space Cool & - & - & - & - & - & - & - & - & - & - & - & - & - \\
\hline Heat Reject. & - & - & - & - & - & - & - & - & - & - & - & - & - \\
\hline Refrigeration & - & - & - & - & - & - & - & - & - & - & - & - & - \\
\hline Space Heat & 1.71 & 1.47 & 1.18 & 0.83 & 0.51 & 0.28 & 0.26 & 0.29 & 0.40 & 0.69 & 1.05 & 1.57 & 10.24 \\
\hline HP Supp. & - & - & - & - & - & - & - & - & - & - & - & - & - \\
\hline Hot Water & 0.04 & 0.03 & 0.04 & 0.04 & 0.04 & 0.03 & 0.03 & 0.03 & 0.03 & 0.03 & 0.03 & 0.03 & 0.39 \\
\hline Vent. Fans & - & - & - & - & - & - & - & - & - & - & - & - & - \\
\hline Pumps \& Aux. & - & - & - & - & - & - & - & - & - & - & - & - & - \\
\hline Ext. Usage & - & - & - & - & - & - & - & - & - & - & - & - & - \\
\hline Misc. Equip. & - & - & - & - & - & - & - & - & - & - & - & - & - \\
\hline Task Lights & - & - & - & - & - & - & - & - & - & - & - & - & - \\
\hline Area Lights & - & - & - & - & - & - & - & - & - & - & - & - & - \\
\hline Total & 1.75 & 1.51 & 1.21 & 0.87 & 0.55 & 0.31 & 0.29 & 0.32 & 0.43 & 0.72 & 1.08 & 1.60 & 10.64 \\
\hline
\end{tabular}


